\title{
Quantification of metal loading in Fisher Creek by tracer injection and synoptic sampling, Park County, Montana, August 1997
}

Water-Resources Investigations Report 99-4119

Prepared in cooperation with the

U.S. Environmental Protection Agency

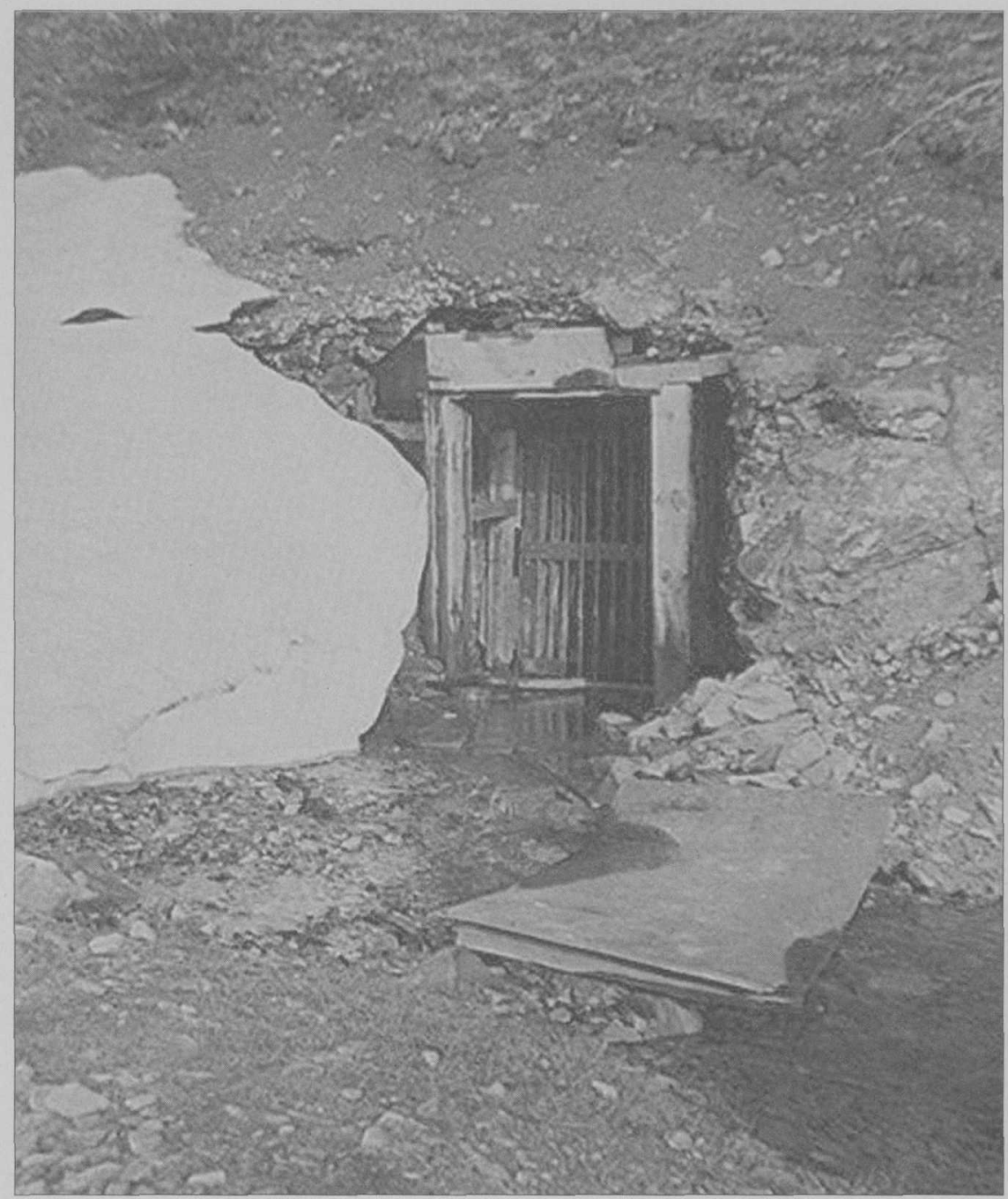


Cover photo, 1997, showing the Glengary Adit discharging mine drainage to Fisher Creek, Montana. 


\section{QUANTIFICATION OF METAL LOADING IN FISHER CREEK BY TRACER INJECTION AND SYNOPTIC SAMPLING, PARK COUNTY, MONTANA, AUGUST 1997}

By Briant A. Kimball, David A. Nimick, Linda J. Gerner, and Robert L. Runkel

U.S. GEOLOGICAL SURVEY

Water-Resources Investigations Report 99-4119

Salt Lake City, Utah 


\title{
U.S. DEPARTMENT OF THE INTERIOR BRUCE BABBITT, Secretary
}

\author{
U.S. GEOLOGICAL SURVEY
}

Charles G. Groat, Director

The use of trade, product, industry, or firm names is for descriptive purposes only and does not imply endorsement by the U.S. Government.

For additional information write to: Copies of this report can be purchased from:

District Chief

U.S. Geological Survey 2329 West Orton Circle

West Valley City, Utah 84119-2047
U.S. Geological Survey

Branch of Information Services

Box 25286

Denver Federal Center

Denver, Colorado 80225

Additional information about water resources in Utah is available on the World Wide Web at $h$ ttp://ut.water.usgs.gov 


\section{CONTENTS}

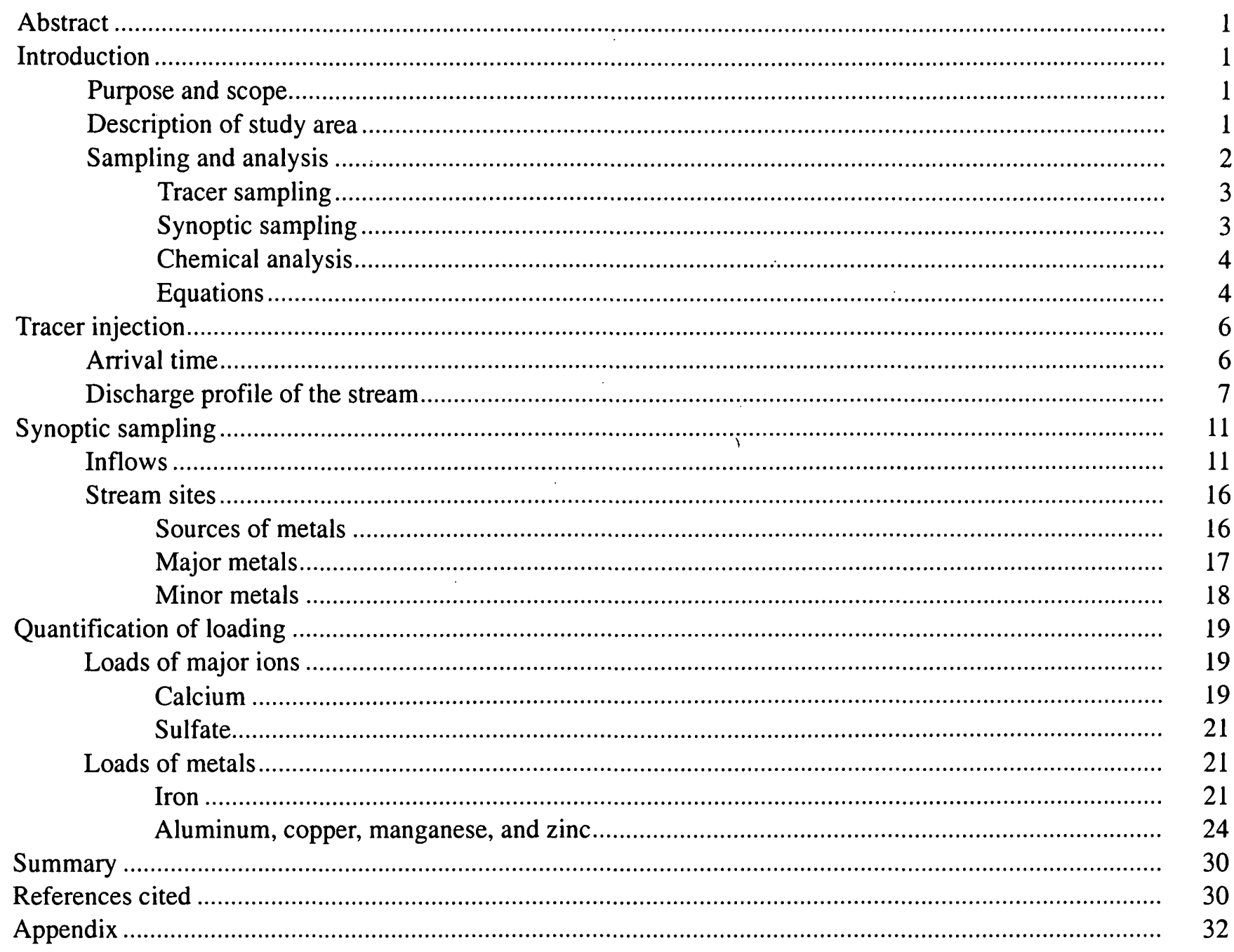

\section{FIGURES}

1. Location of selected surface-water sampling sites along Fisher Creek, Montana ........................... 2

2. Schematic diagram showing mass-balance calculation around an inflow to a stream ..................... 5

3-21. Graphs showing:

3. Variation of chloride concentration with time at transport site $\mathrm{T} 5$

4. Variation of chloride concentration with time at transport site T1

5. Variation of chloride concentration with time at transport site $\mathrm{T} 2$

6. Variation of chloride concentration with time at transport site T3

7. Variation of chloride concentration with time at transport site $\mathrm{T} 4$

8. Variation of (a) chloride concentration and (b) calculated discharge with distance in Fisher Creek, Montana, during synoptic sampling, August 19, 1997

9. Variation of stream and inflow $\mathrm{pH}$ with distance from the injection site, Fisher Creek, Montana, August 19, 1997

10. Variation of normalized concentrations of (a) calcium, filtered copper, and filtered iron; and (b) filtered arsenic, filtered lead, and filtered nickel, with distance from the injection site, Fisher Creek, Montana, August 19, 1997 


\section{FIGURES-Continued}

\section{3-21. Graphs showing:-Continued}

11. Variation of ferrous, filtered, and total-recoverable iron with distance from the injection site, Fisher Creek, Montana, August 19, 1997.

12. (a) Sampled instream load, cumulative total load, and cumulative inflow load of calcium, and (b) net gain or loss of calcium load, Fisher Creek, Montana, August 19, 1997.

13. (a) Sampled instream load, cumulative total load, and cumulative inflow load of sulfate, and

(b) net gain or loss of sulfate load, Fisher Creek, Montana, August 19, 1997

14. (a) Sampled instream load, cumulative total load, and cumulative inflow load of iron, and (b) net gain or loss of iron, Fisher Creek, Montana, August 19, 1997

15. (a) Sampled instream load, cumulative total load, and cumulative inflow load of filtered copper, and (b) net gain or loss of filtered copper load, Fisher Creek, Montana, August 19, 1997.

16. (a) Sampled instream load, cumulative total load, and cumulative inflow load of filtered aluminum, and (b) net gain or loss of filtered aluminum load, Fisher Creek, Montana, August 19, 1997.

17. (a) Sampled instream load, cumulative total load, and cumulative inflow load of filtered manganese, and (b) net gain or loss of filtered manganese load, Fisher Creek, Montana, Auguśt 19, 1997.

18. (a) Sampled instream load, cumulative total load, and cumulative inflow load of filtered zinc, and (b) net gain or loss of filtered zinc load, Fisher Creek, Montana, August 19, 1997....

19. Relation of measured chloride concentration with certified or most probable concentration......

20. Relation of measured sulfate concentration with certified or most probable concentration

21. Variation in concentration of chloride and sulfate with time in standard reference samples

\section{TABLES}

1. Sequence of tracer-injection activities and sampling in Fisher Creek, Montana, August 1997

2. Analysis of synoptic samples collected in Fisher Creek, Montana, August 1997.

3. Transport information, chloride concentrations, and discharge calculations at transport sites downstream from the tracer-injection site, August 18-19, 1997, Fisher Creek, Montana.

4. Characteristics of water and concentrations of major ions in water from synoptic-sampling sites, Fisher Creek, Montana, August 19, 1997.

5. Metal concentration in samples from Fisher Creek, Montana, August 19, 1997.

6. Chemical characteristics of inflow groups from Fisher Creek, Montana, August 1997.

7. Net gain or loss of selected metals and sulfate in stream segments of Fisher Creek, Montana, August 1997.

8. Sample-loop volumes and minimum and maximum chloride and sulfate concentrations of each corresponding set of calibration standards for water samples from Fisher Creek, Montana, August 1997

9. Analysis of chloride and sulfate accuracy and precision from certified standards and standard reference samples from Fisher Creek, Montana, August 1997. 


\section{CONVERSION FACTORS AND ABBREVIATED WATER-QUALITY UNITS}

\begin{tabular}{lll}
\hline \multicolumn{1}{c}{ Multiply } & \multicolumn{1}{c}{ By } & To obtain \\
\hline kilogram $(\mathrm{kg})$ & 2.2046 & pound \\
liter $(\mathrm{L})$ & 0.26417 & gallon \\
meter $(\mathrm{m})$ & 3.2808 & foot \\
micrometer $(\mu \mathrm{m})$ & 0.0000032808 & foot \\
milligram $(\mathrm{mg})$ & 0.000002205 & pound \\
milliliter $(\mathrm{mL})$ & 0.00022642 & gallon \\
\end{tabular}

Water temperature is reported in degrees Celsius $\left({ }^{\circ} \mathrm{C}\right)$, which can be converted to degrees Fahrenheit $\left({ }^{\circ} \mathrm{F}\right)$ by the following equation:

$$
{ }^{\circ} \mathrm{F}=1.8\left({ }^{\circ} \mathrm{C}\right)+32 .
$$

Chemical concentration and water temperature are reported only in metric units. Chemical concentration is reported in grams per liter $(\mathrm{g} / \mathrm{L})$, milligrams per liter $(\mathrm{mg} / \mathrm{L})$, or micrograms per liter $(\mu \mathrm{g} / \mathrm{L})$. Milligrams per liter is a unit expressing the mass of solute per unit volume (liter) of water. One thousand micrograms per liter is equivalent to 1 milligram per liter. For concentrations less than 7,000 milligrams per liter, the numerical value is about the same as for concentrations in parts per million. Specific conductance is reported in microsiemens per centimeter at 25 degrees Celsius $(\mu \mathrm{S} / \mathrm{cm})$. 


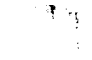




\title{
QUANTIFICATION OF METAL LOADING IN FISHER CREEK BY TRACER INJECTION AND SYNOPTIC SAMPLING, PARK COUNTY, MONTANA, AUGUST 1997
}

\author{
By Briant A. Kimball, David A. Nimick, Linda J. Gerner, and Robert L. Runkel
}

\section{ABSTRACT}

Acid mine drainage from abandoned and inactive mines affects the water quality of the upper reaches of Fisher Creek, Montana. A sodium chloride tracer was added to the stream for 29.5 hours to provide a hydrologic context for synoptic sampling of metal chemistry in the stream and its inflows. The detailed profile of stream discharge obtained from the sampling helped to indicate those areas of Fisher Creek where most of the metal loading occurred. Inflows to the stream can be divided between visible surface inflows, which were sampled, and subsurface inflows, which were not sampled, but the effects of both types of inflows on the stream load were quantified. Substantial loads were attributed to both sources.

These results indicate that treatment of large visible inflows, particularly the Glengary adit, could still leave metal concentrations in Fisher Creek at levels that may adversely affect aquatic life.

\section{INTRODUCTION}

Acid mine drainage from abandoned and inactive mines affects the water quality of Fisher Creek, Montana, a headwater tributary of the Clark's Fork of the Yellowstone River. Planning is in progress for possible clean-up actions to alleviate water-quality degradation in Fisher Creek. Clean-up actions would be more effective and cost-efficient if the primary sources of acid water and metal loads were known and if important instream geochemical processes were well understood.

Metal concentrations in Fisher Creek and its main tributaries have been documented by periodic water-quality sampling (Amacher and others, 1995). Discharge measurements available for a limited number of sites allow calculation of metal loads (M.C. Amacher, U.S. Forest Service, oral commun., 1997).
However, more closely spaced sampling sites are needed for detailed remediation planning.

Spatial variations of $\mathrm{pH}$ and toxic metals in streams affected by acid mine drainage are the result of the interaction of hydrologic and geochemical processes (Bencala and McKnight, 1987; Kimball and others, 1994; Broshears and others, 1995). In several streams affected by acid mine drainage, sources of acid and metals have been identified and quantified by combining tracer-injection methods and spatially intensive synoptic water-quality sampling (Kimball and others, 1994; Kimball, 1997; Kimball and others, 1999). By combining discharge, determined through tracer dilution, with synoptic metal concentrations, these studies have provided the mass-balance information needed to define load profiles for metals. The detailed load information also helps decipher key geochemical processes that affect $\mathrm{pH}$ and metal concentrations in the stream.

\section{Purpose and Scope}

This report has two principal objectives. The first objective is to identify and quantify the principal sources of metal loads to Fisher Creek within the study reach. This is accomplished through a study that combines tracer injection and synoptic sampling. Some of the sources)are visible inflows such as drainage from adits and other mine-related features and other sources are from diffuse subsurface inflows to the stream. The second objective is to describe geochemical processes that affect metal concentrations in the stream.

\section{Description of Study Area}

Fisher Creek is an alpine stream near Cooke City, Montana, that originates at an altitude of more than $3,000 \mathrm{~m}$ (fig. 1). The principal source of stream water is snowmelt runoff, which mostly occurs from May 


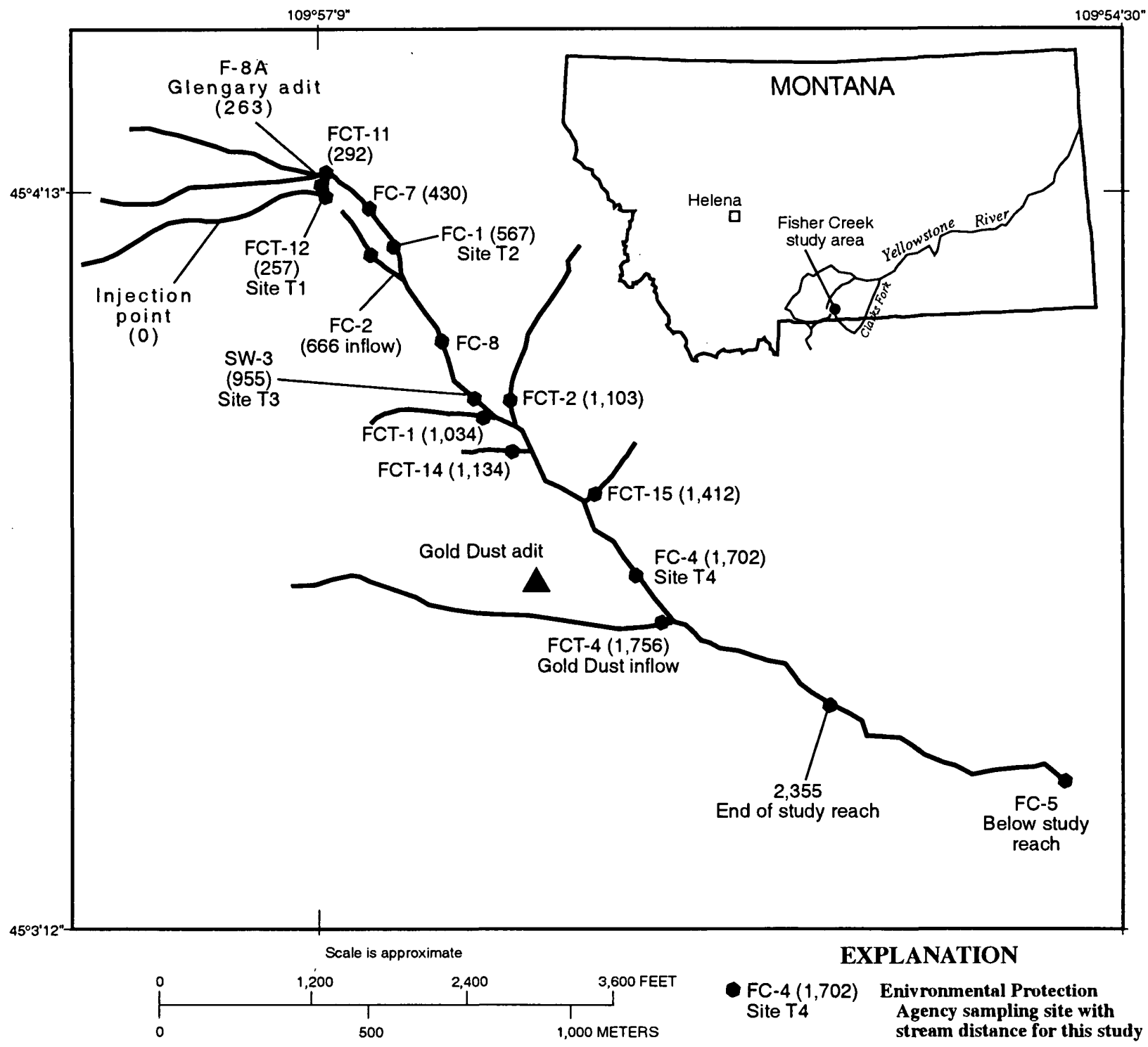

Figure 1. Location of selected surface-water sampling sites along Fisher Creek, Montana.

through July. The stream receives acid mine drainage from the Glengary adit and several seeps and springs. Pools, riffles, and cascades in this small, shallow stream cause rapid mixing of inflows.

\section{Sampling and Analysis}

The tracer-injection study was done in a 2,355-m reach of Fisher Creek for 5 days in August 1997. The tracer injection began at 1130 on August 18 and continued until 1700 on August 19 (table 1). For reporting results, 1130 is the beginning of the experiment time, or 0.0. Subsequent times are reported as decimal hours.
The injection site was about $263 \mathrm{~m}$ upstream from the Glengary adit, in the branch labeled FCT-12, so that drainage from the adit could be quantified as tributary inflow to the stream. A second branch of Fisher Creek, labeled FCT-11, enters the stream $29 \mathrm{~m}$ downstream from the Glengary adit inflow and was treated as a tributary. The $2,355-\mathrm{m}$ reach was divided into 42 segments for synoptic sampling. Sampling sites were located upstream and downstream from selected inflows to allow mass-balance calculations for each inflow. Additional stream sampling sites were located in some of the longer areas without visible inflows to detect any subsurface inflow. The longest of these segments was $120 \mathrm{~m}$, but most of the segments were about $60 \mathrm{~m}$ or less. A total of 23 inflow sampling sites was 
Table 1. Sequence of tracer-injection activities and sampling in Fisher Creek, Montana, August 1997

[ $\mathrm{mL} / \mathrm{min}$, milliliters per minute; $\mathrm{mg} / \mathrm{s}$, milligrams per second]

\begin{tabular}{|c|c|c|c|c|c|}
\hline Date & Time & $\begin{array}{l}\text { Experiment } \\
\text { time } \\
\text { (hours) }\end{array}$ & Activity & $\begin{array}{l}\text { Pump rate } \\
\text { (mL/min) }\end{array}$ & $\begin{array}{l}\text { Injection } \\
\text { rate } \\
(\mathrm{mg} / \mathrm{s})\end{array}$ \\
\hline $8 / 16 / 97$ & 0900 & & $\begin{array}{l}\text { Reconnaissance of stream and inflows to establish } \\
\text { sampling sites and measure downstream dis- } \\
\text { tances from the injection site. }\end{array}$ & & \\
\hline $8 / 17 / 97$ & 0900 & & $\begin{array}{l}\text { Reconnaissance of sites and flow-meter discharge } \\
\text { measurements at sites T2 through T5. }\end{array}$ & & \\
\hline \multirow[t]{3}{*}{$8 / 18 / 97$} & 1130 & 0.0 & $\begin{array}{l}\text { Start of tracer injection; start of sampling for the } \\
\text { tracer arrival at the downstream transport sites. }\end{array}$ & 215.4 & 544.6 \\
\hline & 1700 & 5.5 & Started autosamplers at sites T3, T4, and T5. & & \\
\hline & 2146 & 10.27 & $\begin{array}{l}\text { Pump \#1 failed and pump \#2 started with a slightly } \\
\text { higher injection rate. }\end{array}$ & 236.9 & 599.0 \\
\hline \multirow[t]{3}{*}{$8 / 19 / 97$} & 0800 & 20.5 & Synoptic sampling of stream and inflow sites. & & \\
\hline & 1002 & 22.53 & $\begin{array}{l}\text { Connected new battery to pump \#2, causing a slight } \\
\text { increase in flow rate. }\end{array}$ & 291.2 & 736.1 \\
\hline & 1700 & 29.5 & $\begin{array}{l}\text { End of tracer injection; start of sampling for the tracer } \\
\text { departure at the downstream transport sites. }\end{array}$ & & \\
\hline \multirow[t]{2}{*}{$8 / 20 / 97$} & & & $\begin{array}{l}\text { Continued sampling with autosamplers at down- } \\
\text { stream transport sites. }\end{array}$ & & \\
\hline & 1200 & 48.5 & End of sampling. & & \\
\hline
\end{tabular}

chosen to represent the range of $\mathrm{pH}$ and specific conductance of water entering the stream. Sampling sites and inflow locations are referenced by their distance downstream from the injection site. A previous study (Amacher and others, 1995) used the Glengary adit as a zero point for measuring meters downstream, so the distances in this study are $263 \mathrm{~m}$ longer than in that study.

\section{Tracer Sampling}

A tracer solution of sodium chloride $(\mathrm{NaCl}$; $149.4+/-2.2 \mathrm{~g} / \mathrm{L}$ as $\mathrm{Cl}$ ) was injected into Fisher Creek. During the 29.5-hour injection, variations in the pump rate resulted in changes of the injection rate to the stream (table 1). It was necessary to account for the variations of the injection rate to interpret the downstream tracer concentrations. The arrival of the $\mathrm{NaCl}$ pulse and the development of a plateau concentration were observed at five locations, transport sites $\mathrm{T} 1$ through T5. These sites ranged from 257 to $2,355 \mathrm{~m}$ downstream from the injection site (fig. 1). Numerous samples were collected at all five transport sites to observe the arrival and departure of the tracer. Autosamplers collected tracer samples at T3, T4, and T5 throughout the night. Water samples for tracer analysis were filtered through $0.45-\mu \mathrm{m}$ in-line capsule filters upon collection. Analytical methods are indicated in table 2 .

\section{Synoptic Sampling}

During the plateau period, water samples were collected at the synoptic sites, which included the transport sites. Water samples for metal and anion analysis were collected from the stream and inflows in acidwashed polyethylene bottles. At a temporary field laboratory, splits of each sample were processed for the 
Table 2. Analysis of synoptic samples collected in Fisher Creek, Montana, August 1997 [ $\mu \mathrm{m}$, micrometer]

\begin{tabular}{|c|c|c|}
\hline Analysis & Field treatment & Analytical method \\
\hline Filtered ferrous iron & Filtered $(0.45 \mu \mathrm{m})$, unacidified & $\begin{array}{l}\text { Bipyridine, colorimetric method for ferrous } \\
\text { iron }\end{array}$ \\
\hline $\mathrm{pH}$, specific conductance & Unfiltered, unacidified & Ion-sensitive electrode \\
\hline Chloride tracer concentrations and sulfate & Filtered $(0.45 \mu \mathrm{m})$, unacidified & lon chromatography \\
\hline Filtered metal concentrations & Filtered $(0.45 \mu \mathrm{m})$, acidified & $\begin{array}{l}\text { Inductively coupled argon plasma-atomic } \\
\text { emission spectrometer--(ICP-AES) }\end{array}$ \\
\hline Total-recoverable metal concentrations & Unfiltered, acidified & $\begin{array}{l}\text { ICP-AES with standard U.S. Environmen- } \\
\text { tal Protection Agency digestion for total- } \\
\text { recoverable concentrations }\end{array}$ \\
\hline
\end{tabular}

different analyses (table 2). Filtration was with 0.45 $\mu \mathrm{m}$ in-line capsule filters to meet regulatory requirements of the U.S. Environmental Protection Agency (EPA). This filtration provided an operational definition of dissolved metal concentrations, not a truly dissolved metal concentration (Kimball and others, 1995). These concentrations are referred to as filtered, rather than dissolved, to emphasize this operational definition for metals.

\section{Chemical Analysis}

Ferrous iron, $\mathrm{pH}$, and specific conductance were measured in the field on the same day the samples were collected. Chloride and $\mathrm{SO}_{4}$ were analyzed by the U.S. Geological Survey at the Utah District Office. Quality assurance methods and results for precision of the anion analyses are presented in the appendix. For samples with concentrations of $\mathrm{Cl}$ greater than about $60 \mathrm{mg} / \mathrm{L}$ the precision was 5.4 percent. For the majority of the stream, however, the precision of $\mathrm{Cl}$ analysis was 2.4 percent. This allows the detection of much smaller changes in discharge than could be accomplished with a flow-meter measurement.

Metals were analyzed by an EPA contract laboratory, and quality assurance procedures for the contract were followed. A flat value of 5 percent precision was assumed for the metals data.

\section{Equations}

When a constant-rate injection is continued for a sufficient length of time, an equilibrium condition develops in which a tracer-plateau concentration occurs at each downstream site. The injection rate and injec- tate concentration are known, so the downstream concentration of the tracer in the stream provides for a calculation of stream discharge at the first sampling point downstream from the injection site:

$$
Q_{A}=\frac{Q_{I n j}\left(C_{I n j}-C_{0}\right)}{\left(C_{A}-C_{0}\right)}
$$

where $Q_{A}$ is the stream discharge at the first downstream site,

$C_{I n j}$ is the tracer concentration in the injection solution,

$Q_{I n j}$ is the rate of the tracer injection into the stream,

$C_{A}$ is the tracer concentration at the first site downstream from the tracer injection, and

$C_{0}$ is the background tracer concentration upstream from the injection site.

The discharge at the first site downstream from the injection, $Q_{A}$, is used to calculate the discharge at the next site, and each subsequent sampling site by using the equation:

$$
Q_{B}=\frac{Q_{A}\left(C_{A}-C_{I}\right)}{\left(C_{B}-C_{I}\right)}
$$

where $Q_{B}$ is the discharge at the downstream site,

$Q_{A}$ is the upstream discharge,

$C_{A}$ is the upstream tracer concentration,

$C_{I}$ is the tracer concentration in water entering the stream between sites $\mathrm{A}$ and $\mathrm{B}$, and

$C_{B}$ is the tracer concentration at the SPdown-stream site. 
Where there was no inflow sample between consecutive stream sites, the median $C_{I}$ concentration for all the inflow samples was substituted for $C_{I}$. The increase of discharge for each of the 42 segments was the difference between the upstream and downstream discharge for each segment and could be due to visible surface inflows and subsurface inflow.

It is helpful to compare the variations of the different concentration profiles among all the metals. Variation of a metal concentration in a stream should be viewed relative to some defined measure. The instream metal concentration generally will reach some value that is between the maximum and minimum concentrations of inflows (Bencala and McKnight, 1987). There can be a wide range of concentrations among the metals from mine drainage. Normalization of concentrations relative to the sampled range of inflow concentrations renders the various metals more comparable. Instream concentrations are normalized by the equation (Bencala and McKnight, 1987):

$$
C_{N O R M}=\frac{\left(C_{S}-C_{M I N}^{I}\right)}{\left.\left(C_{M A X}^{I}\right)-C_{M I N}^{I}\right)}
$$

where $C_{N O R M}$ is the normalized concentration relative to the range of inflow concentrations,

$C_{S} \quad$ is the instream concentration at a given distance downstream from the injection,

$C_{M I N}^{I}$ is the minimum inflow concentration

for the metal, and

$C_{M A X}^{I}$ is the maximum inflow concentration for the metal.

This ratio of concentrations will be 1.0 if the instream concentration is equal to the maximum inflow concentration and will be 0.0 if the instream concentration is equal to the minimum inflow concentration.

During the plateau condition, synoptic sampling provided a spatially intensive "snapshot" of the instream conditions that included chemistry and discharge. Logistically, taking the snapshot of several kilometers of a stream required sampling over a period of hours. Load $(\mathrm{mg} / \mathrm{s})$ is the product of concentration $(\mathrm{mg} / \mathrm{L})$ and discharge $(\mathrm{L} / \mathrm{s})$ and can be calculated for any stream site. For site $\mathrm{A}$, load would be $Q_{A} C_{A}$ (fig. 2). The instream change in mass between the upstream site $A$ and the downstream site $B, \Delta M_{S}$, is calculated from the equation:

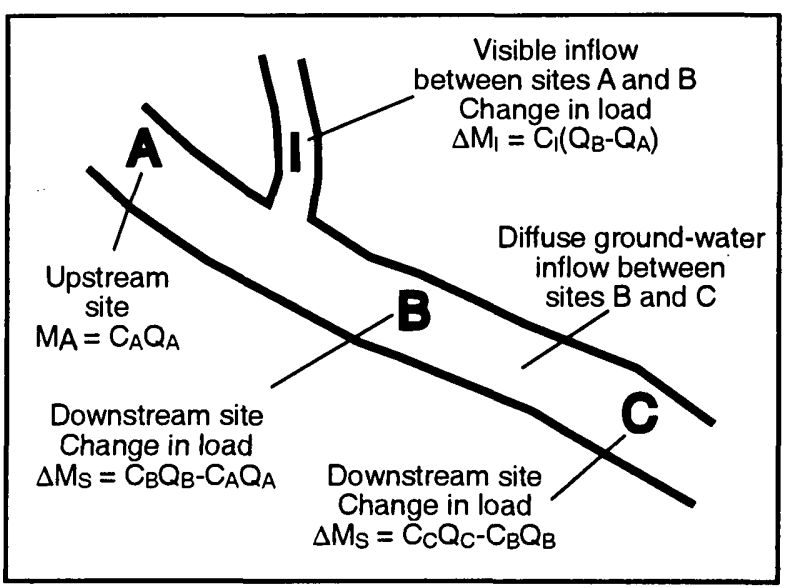

Figure 2. Schematic diagram showing mass-balance calculation around an inflow to a stream.

$$
\Delta M_{S}=\left(Q_{B} C_{B}-Q_{A} C_{A}\right)
$$

where $\Delta M_{S}$ is the net change in stream load between sites $\mathrm{A}$ and $\mathrm{B}$,

$Q_{B}$ is the discharge at site $\mathrm{B}$,

$C_{B}$ is the metal concentration at site $\mathrm{B}$,

$Q_{A}$ is the discharge at site $\mathrm{A}$, and

$C_{A}$ is the metal concentration at site $\mathrm{A}$.

There are two ways to account for $\Delta M_{S}$ between stream sites. If a sampled inflow concentration, $C_{l}$, represents the concentration of all the water entering between sites $A$ and $B$, then the change in mass also can be calculated from:

$$
\Delta M_{I}=C_{I}\left(Q_{B}-Q_{A}\right)
$$

where $\Delta M_{I}$ is the net change in stream load between sites $\mathrm{A}$ and $\mathrm{B}$, assuming that $C_{I}$ represents all the water entering the stream between sites $A$ and $B$. This is called the "sampled inflow load" for this study.

Alternatively, if there was no visible inflow, but a subsurface contribution to the load between sites A and $B$ caused an increase in load, then the average inflow concentration for the segment can be calculated by rearranging equation 5 to solve for $C_{I}$ to represent the ground-water concentration. If the metal was removed by chemical reaction between $A$ and $B$, however, the calculated value of $C_{I}$ will be an underestimate of the average inflow concentration. To resolve the fraction of ground-water and surface-water contributions, more information is needed about the ground water. This limitation represents a best approach at this time.

A negative value of $\Delta M_{S}$ represented the mass of metal removed from the stream by instream processes. Any removal can mask inflows that occur in the area. 
Effects of instream processes are most evident when the sampled instream load is compared with a cumulative total load. This load is calculated by summing all the positive values of $\Delta M_{S}$. For each stream segment, however, $\Delta M_{S}$ represents a net change in load, so that it may represent some loss of mass. Thus, the cumulative total load represents a minimum estimate of the total load. These possibilities are summarized as follows:

\begin{tabular}{|c|c|}
\hline Condition & Probable explanation \\
\hline$\Delta M_{S}=\Delta M_{l}$ & $\begin{array}{l}\text { The value of } C_{\text {, represents the }} \\
\text { concentration of all the water } \\
\text { entering the stream. }\end{array}$ \\
\hline$\Delta M_{S}>\Delta M_{l}$ & $\begin{array}{l}\text { Subsurface inflow has a concen- } \\
\text { tration greater than } C_{l} \text {. }\end{array}$ \\
\hline$\Delta \cdot M_{S}<\Delta M_{l}$ & $\begin{array}{l}\text { Could indicate two conditions: (1) } \\
\text { load is lost through chemical } \\
\text { reaction within the subreach or } \\
\text { (2) subsurface inflow has a } \\
\text { concentration less than } C_{l} \text {. }\end{array}$ \\
\hline$\Delta M_{S}<0$ & $\begin{array}{l}\text { There is a net loss of load through } \\
\text { chemical reaction within the } \\
\text { stream subreach. }\end{array}$ \\
\hline
\end{tabular}

\section{TRACER INJECTION}

A load analysis must be based on accurate discharge measurements. Tracer-injection studies typically provide a more accurate discharge for loading analysis than flow-meter measurements for cobble-bottomed, mountain streams (Kimball, 1997). The calculation of arrival time is described using data from site T5.

\section{Arrival Time}

An injected tracer moving downstream without dispersion or transient storage would arrive at a downstream site with a very sharp concentration front. On a graph of concentration versus time, this front would look like a box, going from a background concentration near zero to the plateau concentration instantly. Likewise, the concentration would decrease sharply from the plateau to the background concentration after the injection stopped. As a result of dispersion and, more importantly, transient storage, the arrival of a tracer is spread out over time so there is a shoulder on the front edge of the box and a tail after the box (Stream Solute Workshop, 1990).

By convention, the arrival time at a site is defined as the time at which the instream-tracer concentration reaches half of the plateau concentration (Zellweger and others, 1988). Residence time between two sites is the difference in arrival times. The breakthrough time, also by convention, is defined as the time when the instream tracer concentration is double the pre-injection concentration.

Because of the drop in altitude of more than $50 \mathrm{~m}$ from the injection site to the first transport site $\mathrm{T} 1$, the arrival time for traveling the $257 \mathrm{~m}$ was expected to be about 20 minutes. However, the arrival of the tracer was profoundly delayed. A possible explanation of this delay is a flow path through alpine soils near the injection site. More than 4 hours passed before the transient storage capacity of the soils was filled and the plateau was reached at site $\mathrm{T} 1$.

Not only was the tracer delayed, but problems with the pumps resulted in three different pump rates (table 1). From the start of the injection at 1130 until 2146 on August 18, the pump rate was $215 \mathrm{~mL} / \mathrm{min}$, delivered by pump \#1. From 2146 hours on August 18 , when pump \#1 failed, pump \#2 delivered a rate of 237 $\mathrm{mL} / \mathrm{min}$ until 1002 on August 19. At that time, a new battery was connected to pump \#1 causing the flux to increase to $291 \mathrm{~mL} / \mathrm{min}$. This rate remained steady until the end of the injection at 1700 on August 19. Even with the complications, however, the arrival times and plateau concentrations of the tracer could be calculated at the transport sites.

Data for site T5 are used to demonstrate how tracer arrival times and plateau concentrations were calculated and how adjustments were made to account for the changes in pump rate (fig. 3). Solid vertical lines represent the start of the injection, the start of pump \#2, changing the pump \#2 battery, and the end of the injection. The clearest signal in the concentration data for site T5 was the breakthrough at 3.17 hours in response to the initial tracer injection. The dashed vertical line in figure 3 after each pump event represents this time interval. This 3.17-hour interval compared very well with the decrease in tracer concentration after the injection was stopped.

Different plateau concentrations should have been observed for each of the three pump rates. However, no clear plateau levels occurred because of the temporal overlap of the tracer movement caused by each change in rate. At 13.2 hours, the tracer at site T5 may have been close to the first plateau level. However, this plateau is not well defined because the tracer concentration increased in response to the increased flux caused by the switch to pump \#2. A second plateau at $2.75 \mathrm{mg} / \mathrm{L}$ is evident at about 23 hours. Similar to the 


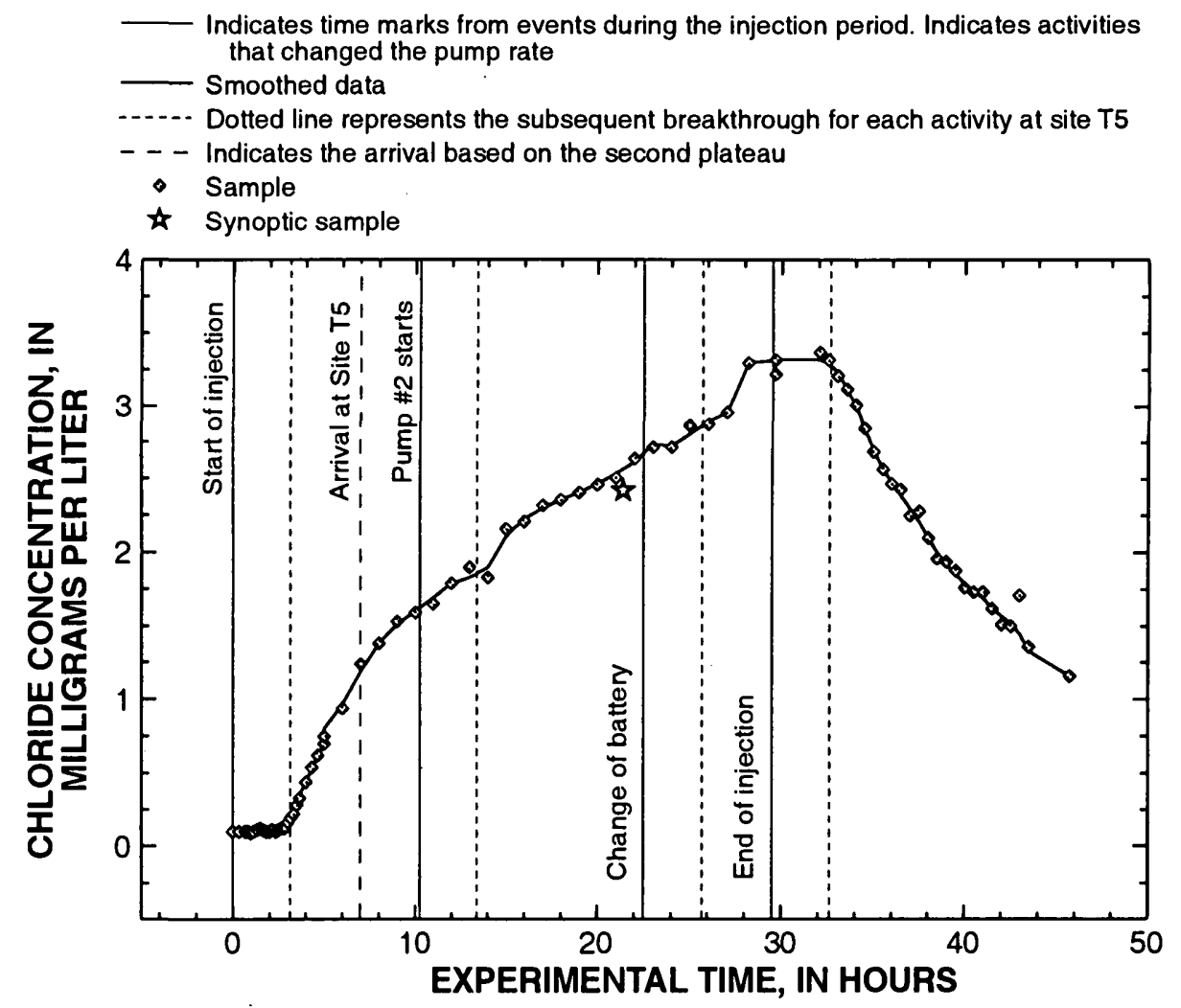

Figure 3. Variation of chloride concentration with time at transport site T5.

first plateau, the second plateau occurred about 13 hours after the change in pump rate. The third plateau may have been near $3.3 \mathrm{mg} / \mathrm{L}$ and occurred between about 28 and 32 hours. This plateau started only about 6 hours after the related change in pump rate so it is not clear whether this plateau is real. The second plateau level is considered the most definitive because it occurred during the longest period of constant pump rate.

Using the second, most probable plateau level of $2.75 \mathrm{mg} / \mathrm{L}$ and the ratio of the injectate fluxes for the first and second levels, the first plateau level would be:

$$
2.75 \mathrm{mg} / \mathrm{L}\left(\frac{544.6}{599.0}\right)=2.5 \mathrm{mg} / \mathrm{L} \text {. }
$$

The time at which half of $2.5 \mathrm{mg} / \mathrm{L}$ reached site $\mathrm{T} 5$ was 7 hours. This represents the residence time for the entire study reach. From site T2 to site T5, the residence time was only about 3 hours; retention of tracer upstream from site T2 accounted for the other 4 hours.

This same reasoning was followed to find the second plateau concentration and the arrival time for sites $\mathrm{T} 1$ through $\mathrm{T} 4$. The tracer data for all the transport sites are shown in figures 3 to 7 . Because the tracer was delayed upstream from site $\mathrm{T} 1$, the arrival times at sites
T1 and T2 almost occurred after the manual tracer sampling ended on August 18. Arrival times at sites T3, T4, and $\mathrm{T} 5$ were sampled because autosamplers collected samples through the night. A summary of the transport information for each of these sites is listed in table 3 , along with adjusted plateau and synoptic $\mathrm{Cl}$ concentrations and discharge calculations at the sites.

Discharges calculated from the tracer concentrations were greater than those calculated by flow-meter measurements on August 17. At sites T2 and T3, the values were comparable. At sites T4 and T5, the tracerdetermined discharges were much greater. This difference might indicate that there was more hyporheic flow at downstream sites. However, because there was rain at night between the flow-meter and the tracer-dilution measurements, the difference might also have been affected by the storm, but this kind of difference would likely have been observed at the upstream sites as well.

\section{Discharge Profile of the Stream}

A detailed discharge profile for a stream can be developed using the tracer concentrations in each synoptic sample. Calculation of these discharges for a 
Table 3. Transport information, chloride concentrations, and discharge calculations at transport sites downstream from the tracer-injection site, August 18-19, 1997, Fisher Creek, Montana

[mg/L, milligrams per liter; $\mathrm{L} / \mathrm{s}$, liter per second; NM, no measurement]

\begin{tabular}{|c|c|c|c|c|c|c|c|c|}
\hline $\begin{array}{l}\text { Transport } \\
\text { site }\end{array}$ & $\begin{array}{c}\text { Distance } \\
\text { from } \\
\text { injection } \\
\text { site } \\
\text { (m) }\end{array}$ & $\begin{array}{l}\text { Pre-injection } \\
\text { chloride } \\
\text { (mg/L) }\end{array}$ & $\begin{array}{l}\text { Synoptic } \\
\text { chloride } \\
\text { (mg/L) }\end{array}$ & $\begin{array}{l}\text { Plateau } \\
\text { chloride } \\
\text { (mg/L) }\end{array}$ & $\begin{array}{c}\text { Arrival } \\
\text { time } \\
\text { (hours) }\end{array}$ & $\begin{array}{c}\text { Residence } \\
\text { time } \\
\text { between } \\
\text { sites } \\
\text { (hours) }\end{array}$ & $\begin{array}{l}\text { Plateau } \\
\text { discharge } \\
\text { (L/s) }\end{array}$ & $\begin{array}{c}\text { Flow- } \\
\text { meter } \\
\text { discharge } \\
(\text { L/s) }\end{array}$ \\
\hline$T 1$ & 257 & 0.09 & 238 & 201 & 4.88 & 4.88 & 3.0 & NM \\
\hline T2 & 567 & .30 & 19.8 & 19.8 & 5.86 & .98 & 30 & 23 \\
\hline T3 & 955 & .21 & 12.2 & 11.2 & 6.15 & .29 & 54 & 44 \\
\hline T4 & 1,702 & .07 & 4.2 & 4.3 & 6.49 & .34 & 141 & 77 \\
\hline T5 & 2,355 & .11 & 2.4 & 2.75 & 7.00 & .51 & 227 & 133 \\
\hline
\end{tabular}

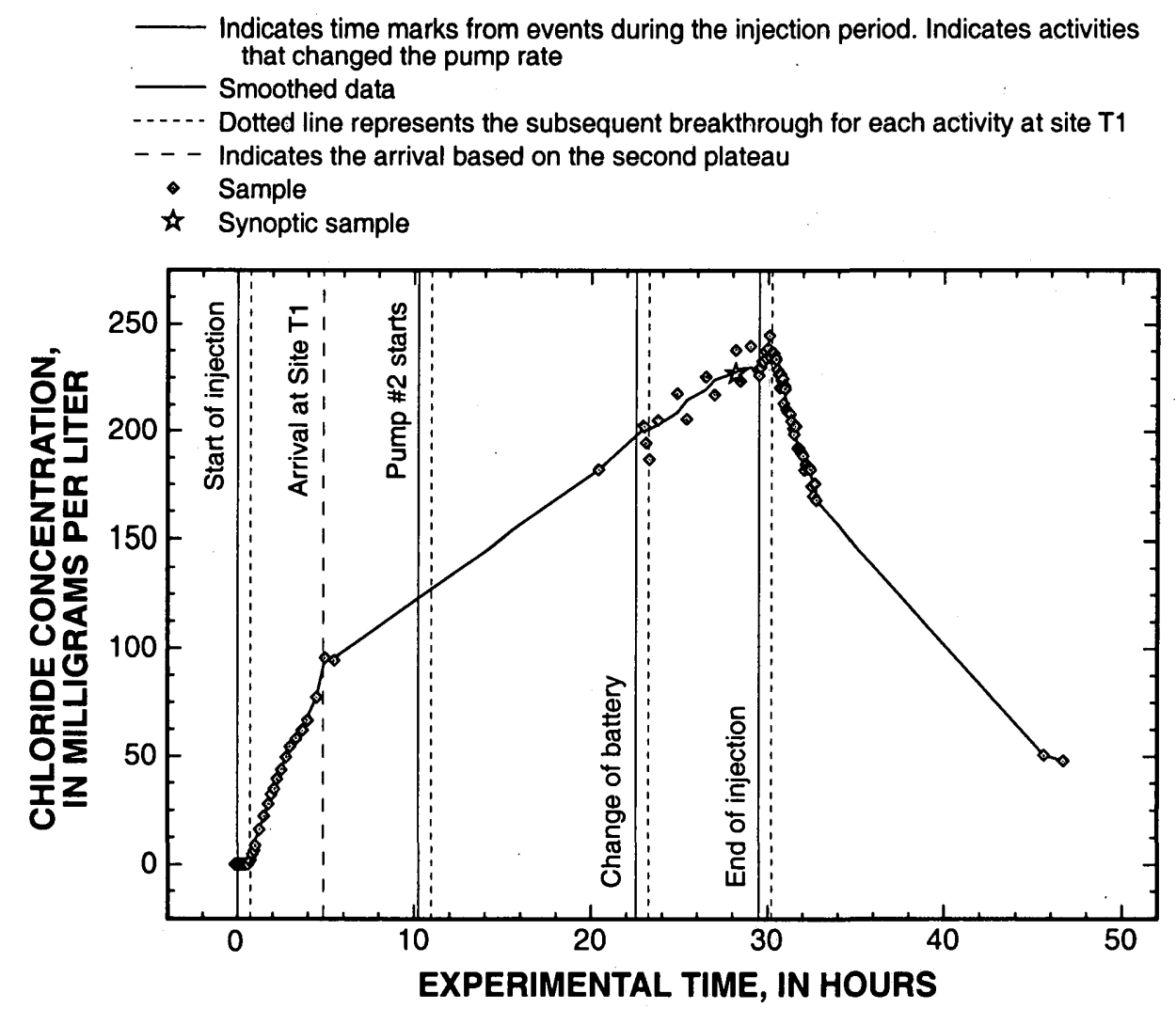

Figure 4. Variation of chloride concentration with time at transport site T1. 


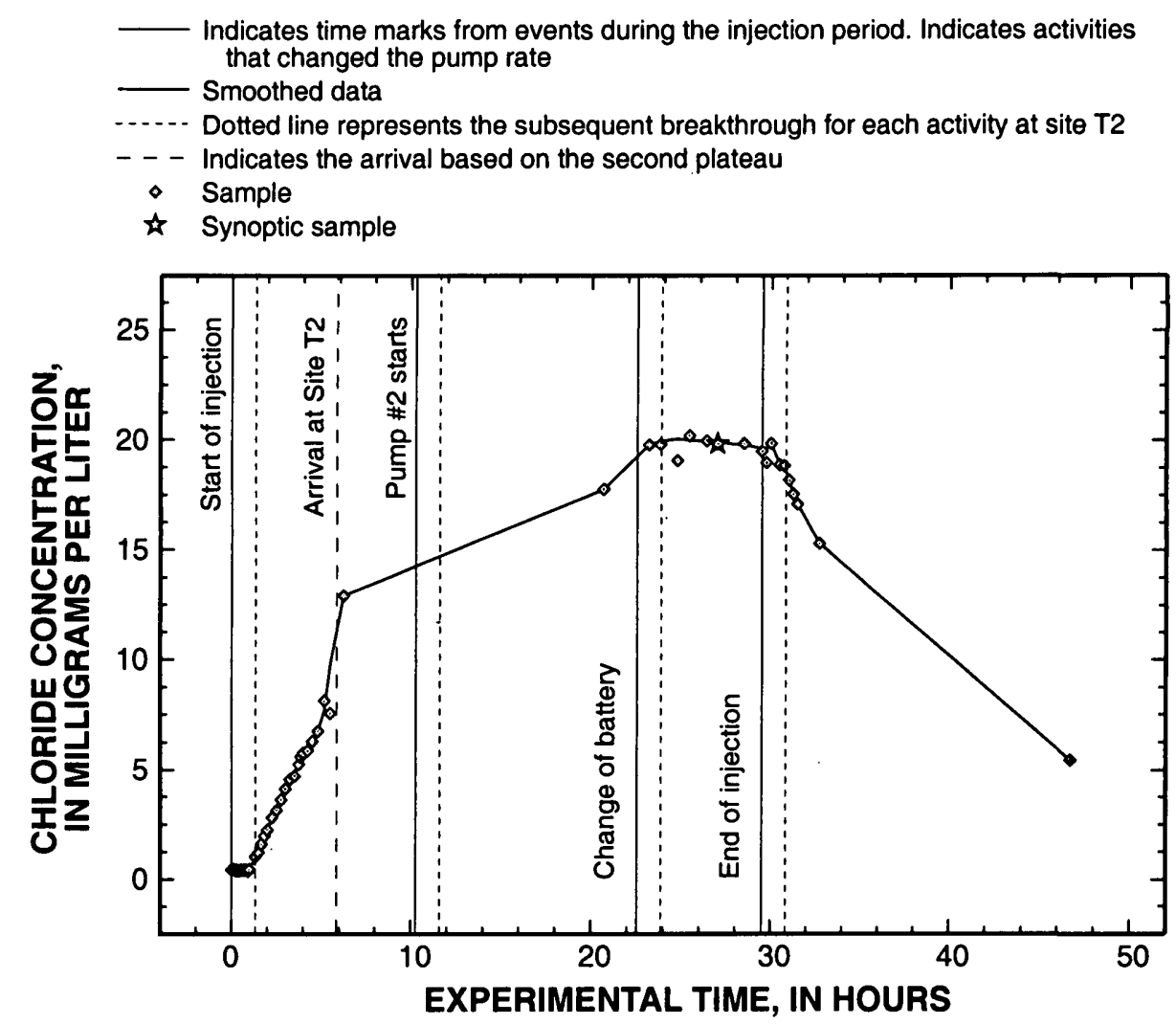

Figure 5. Variation of chloride concentration with time at transport site $\mathrm{T} 2$.

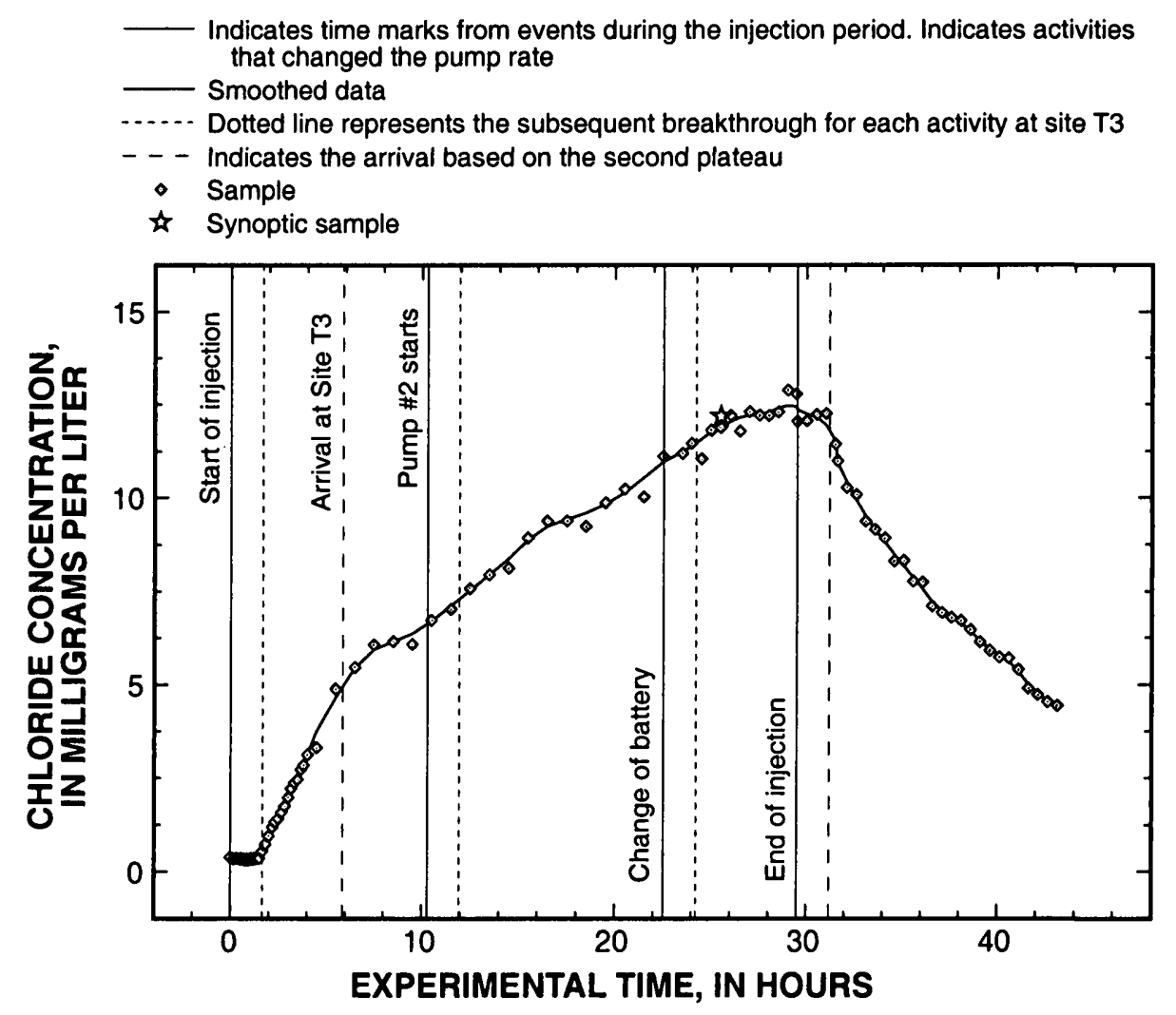

Figure 6. Variation of chloride concentration with time at transport site T3. 


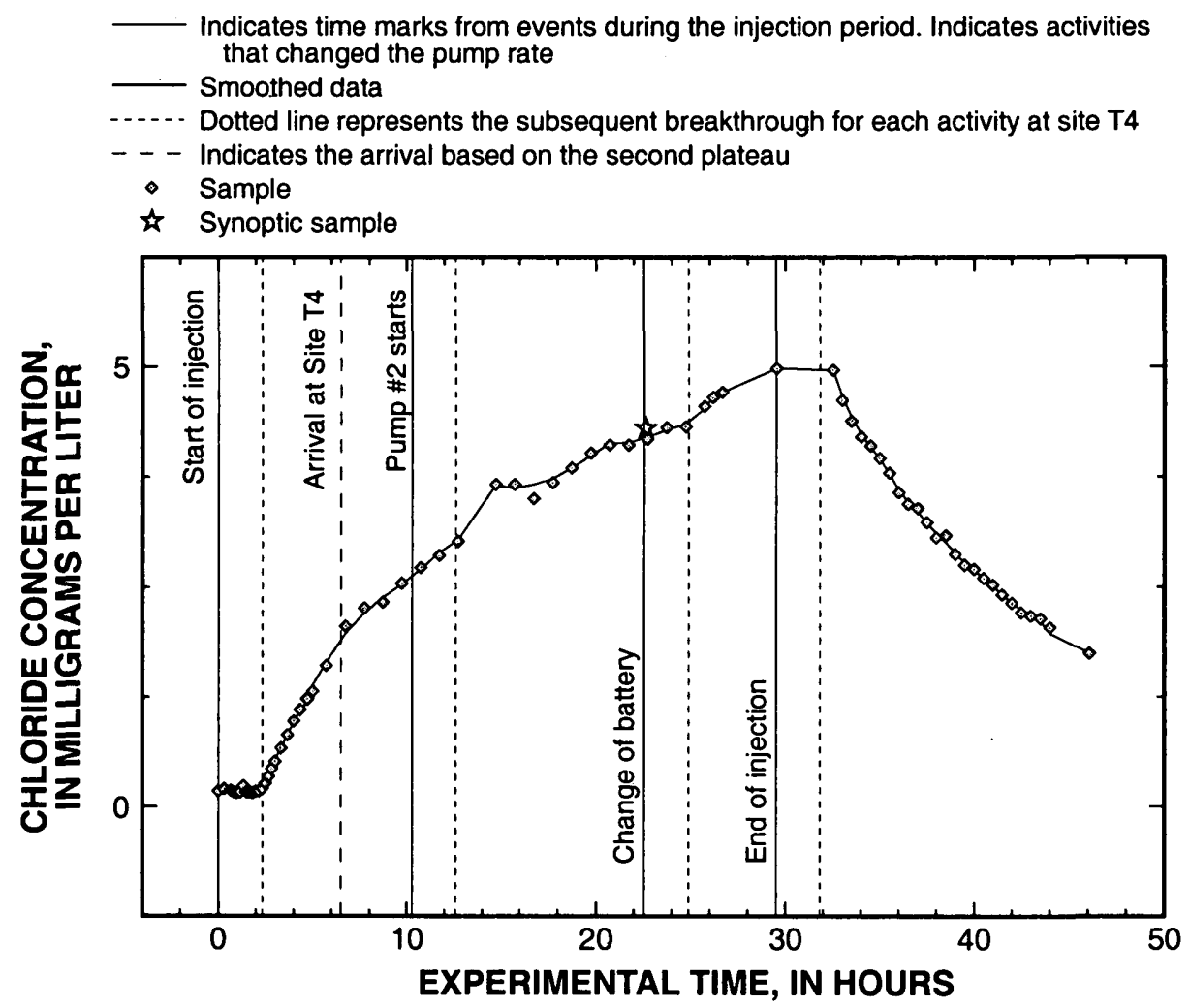

Figure 7. Variation of chloride concentration with time at transport site T4.

tracer-injection study depends on two conditions. First, the tracer concentration in the stream should be consistently higher than the concentration in the inflows. This condition was realized with the instream $\mathrm{Cl}$ concentration during the synoptic sampling (fig. 8a). None of the inflows had a $\mathrm{Cl}$ concentration greater than $0.25 \mathrm{mg} / \mathrm{L}$ and the median was $0.13 \mathrm{mg} / \mathrm{L}$. Second, the tracer concentration in each synoptic sample should represent the steady-state plateau concentration at that sampling site. The variation of the injection rate prevented this condition at some sites. As noted above, the second plateau level was better defined and therefore was used for calculating discharge. $\mathrm{Cl}$ concentrations in some synoptic samples needed to be adjusted because the second plateau level was moving downstream as synoptic samples were being collected in an upstream order. The synoptic $\mathrm{Cl}$ concentration was greater than the second plateau at site $\mathrm{T} 1$, comparable at sites $\mathrm{T} 2, \mathrm{~T} 3$, and $\mathrm{T} 4$, and less than the plateau level at site T5. Although the concentration differences between plateau and synoptic $\mathrm{Cl}$ concentrations were small, they resulted in a substantial difference in discharge calculations (fig. 8b).

Synoptic $\mathrm{Cl}$ concentrations downstream from site $\mathrm{T} 4$ were adjusted by calculating the difference between synoptic and plateau concentrations at sites T4 and T5. Differences at the two points were regressed against the sample collection time, and then a shift was calculated for all the individual sampling times at all the synoptic sites between T4 and T5. This temporal correction accounted for the shift, which was greatest in the morning and grew smaller as samples were collected upstream.

The difficulty with the pumps could not be foreseen, but if the delay in the tracer arrival could have been anticipated, an extra day of injection would have been allowed before the synoptic sampling began so that all the sites would have had more time at the plateau concentration. Any future injection site in Fisher Creek should be downstream from the soils that caused the delay in the tracer.

The total gain of water downstream from site T1 was $227 \mathrm{~L} / \mathrm{s}$. The segments with visible inflows accounted for 65 percent of this flow, leaving 35 percent attributable to small seeps and subsurface inflows. Almost 60 percent of the gain occurred in just eight stream segments, including both visible and subsurface inflows. The largest visible inflows occurred at $1,103 \mathrm{~m}$ (FCT-2); 2,116 m (a wetland inflow); $292 \mathrm{~m}$ (FCT-11), 


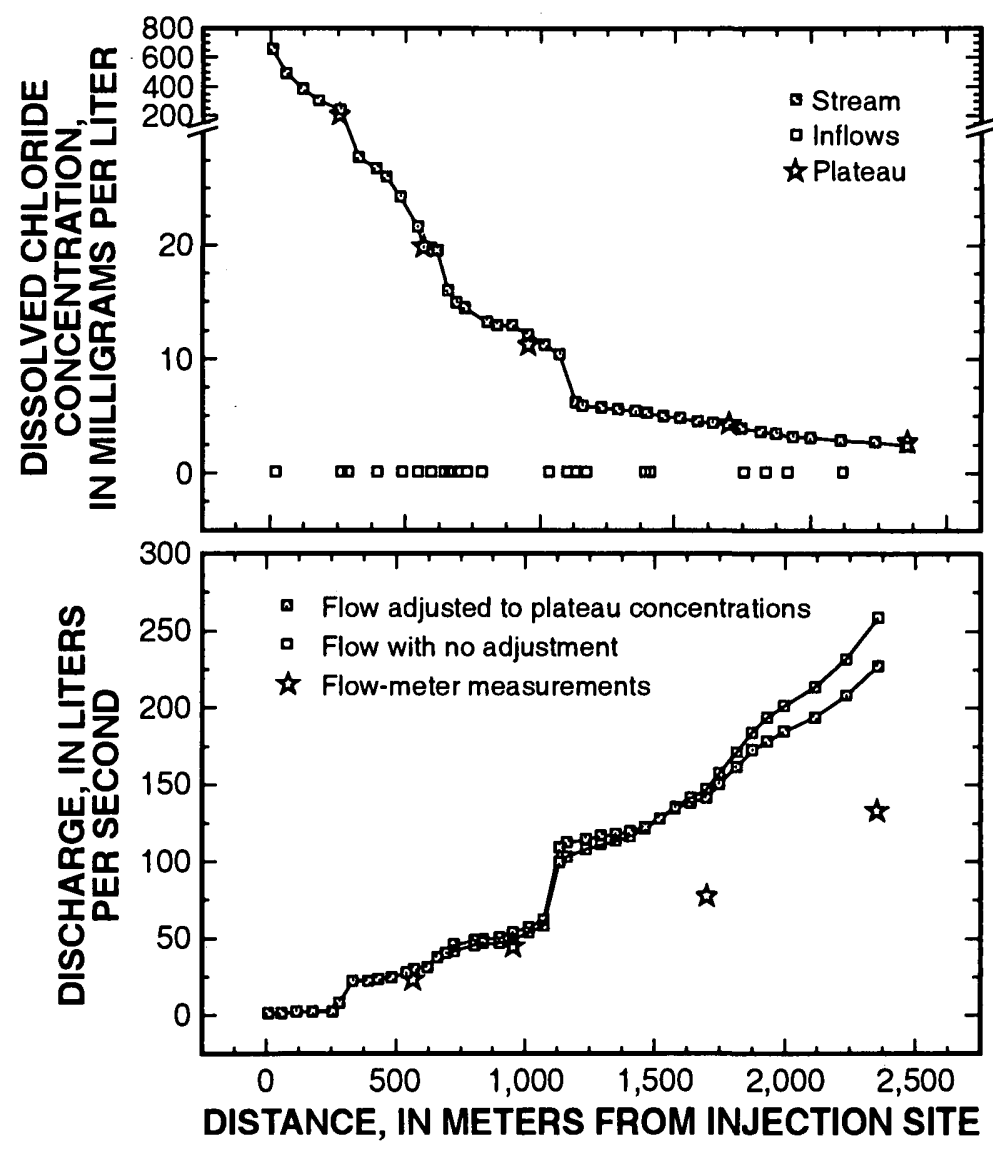

Figure 8. Variation of (a) chloride concentration and (b) calculated discharge with distance in Fisher Creek, Montana, during synoptic sampling, August 19, 1997.

$1,756 \mathrm{~m}$ (FCT-4), 1,834 $\mathrm{m}$ (a wetland inflow); and 645 $\mathrm{m}$ (FC-2, drainage from a mine waste-rock pile just below the Glengary adit). The Glengary adit, at $263 \mathrm{~m}$, added only $4.8 \mathrm{~L} / \mathrm{s}$, but had a profound effect on the metal concentrations.

Substantial subsurface inflow also occurred in many stream segments. The greatest subsurface inflow $(28 \mathrm{~L} / \mathrm{s})$ occurred between $1,462 \mathrm{~m}$ and $1,750 \mathrm{~m}$. This inflow was significant because of the metal loads that it contributed to Fisher Creek. Other substantial subsurface inflows occurred between $1,936 \mathrm{~m}$ and $2,000 \mathrm{~m}$ and between $2,235 \mathrm{~m}$ and $2,355 \mathrm{~m}$. Both of these were nonacidic inflows that affected the metal chemistry downstream.

\section{SYNOPTIC SAMPLING}

Results of chemical analysis of water from the synoptic sampling sites are listed in tables 4 and 5. Data are sorted in downstream order within groups of stream and inflow sites to emphasize the downstream changes.

\section{Inflows}

The chemical character of water in Fisher Creek changed in response to the chemistry of inflows. The downstream profile of $\mathrm{pH}$ provides an overview of the changes, indicating three important divisions for the study reach (fig. 9). First, upstream from the Glengary adit, Fisher Creek was acidic, indicating that there were sources of acid drainage. Natural weathering of the intrusive porphyritic rock high in the watershed may have been the source of this acid drainage. Acidic inflows downstream, however, had much more effect on the stream chemistry. The second geochemical division began at $263 \mathrm{~m}$, where the Glengary adit inflow caused the lowest $\mathrm{pH}$ and the highest metal concentrations in Fisher Creek. This division extended downstream to about $1,715 \mathrm{~m}$. A combination of acidic and near-neutral $\mathrm{pH}$ inflow in this second division, resulted in the gradual increase of $\mathrm{pH}$. In the final division of the stream, downstream from $1,715 \mathrm{~m}, \mathrm{pH}$ increased sub- 
Table 4. Characteristics of water and concentrations of major ions in water from synoptic-sampling sites, Fisher Creek, Montana, August 19, 1997

[Trib, stream=0, inflow=1; Distance, distance from injection site, in meters; EPA name, U.S. EPA designation for sites; Temp, water temperature, in degrees Celsius; $\mathrm{pH}$, in standard units; specific conductance, $\mathrm{K}_{\mathrm{sc}}$, in microSiemens per centimeter at 25 degrees Celsius; all major ions in milligrams per liter]

\begin{tabular}{|c|c|c|c|c|c|c|c|c|c|c|c|}
\hline Trib & Distance & EPA name & Time & Temp & $\mathrm{pH}$ & $K_{s c}$ & Calcium & Magnesium & Sodium & Chloride & Sulfate \\
\hline 0 & 10 & & 1620 & 12.7 & 4.30 & 2,190 & 2.57 & 0.57 & 404 & 652 & 40.1 \\
\hline 0 & 60 & & 1605 & 14.4 & 4.18 & 1,589 & 2.82 & .56 & 288 & 480 & 36.3 \\
\hline 0 & 120 & & 1555 & 14.4 & 4.07 & 1,293 & 2.92 & .50 & 227 & 383 & 41.1 \\
\hline 0 & 180 & & 1550 & 13.8 & 3.94 & 1,024 & 3.39 & .58 & 171 & 303 & 40.6 \\
\hline 0 & 280 & & 1527 & 10.0 & 3.08 & 1,322 & 40.2 & 11.7 & 47.8 & 77.1 & 376 \\
\hline 0 & 330 & & 1520 & 13.5 & 3.12 & 600 & 18.7 & 5.02 & 17.2 & 27.6 & 204 \\
\hline 0 & 390 & & 1515 & 13.5 & 3.10 & 578 & 18.7 & 4.96 & 17.1 & 26.8 & 196 \\
\hline 0 & 430 & FC-7 & 1503 & 13.5 & 3.20 & 593 & 18.6 & 4.95 & 16.6 & 25.9 & 195 \\
\hline 0 & 482 & & 1500 & 14.0 & 3.17 & 565 & 18.5 & 4.88 & 15.8 & 23.5 & 190 \\
\hline 0 & 542 & & 1445 & 14.1 & 3.12 & 522 & 18.1 & 4.69 & 14.5 & 21.7 & 183 \\
\hline 0 & 567 & FC-1 & 1430 & 15.0 & 3.14 & 501 & 17.5 & 4.48 & 13.5 & 20.0 & 177 \\
\hline 0 & 618 & & 1422 & 13.8 & 3.19 & 495 & 16.9 & 4.40 & 13.3 & 18.3 & 172 \\
\hline 0 & 659 & & 1417 & 14.4 & 3.27 & 436 & 15.4 & 3.99 & 11.1 & 16.5 & 167 \\
\hline 0 & 692 & & 1355 & 15.4 & 3.28 & 407 & 15.0 & 3.94 & 10.7 & 15.0 & 163 \\
\hline 0 & 725 & & 1242 & 15.0 & 3.21 & 390 & 14.7 & 3.84 & 10.4 & 14.1 & 158 \\
\hline 0 & 802 & & 1320 & 16.4 & 3.33 & 370 & 14.0 & 3.70 & 9.77 & 13.4 & 154 \\
\hline 0 & 840 & & 1315 & 17.0 & 3.34 & 370 & 13.9 & 3.63 & 9.59 & 13.0 & 150 \\
\hline 0 & 900 & & 1306 & 16.6 & 3.41 & 362 & 13.6 & 3.54 & 9.36 & 12.7 & 148 \\
\hline 0 & 955 & SW-3 & 1300 & 17.6 & 3.42 & 354 & 13.2 & 3.47 & 9.07 & 12.1 & 147 \\
\hline 0 & 955 & SW-3 & 1300 & 17.6 & 3.42 & 354 & 13.5 & 3.52 & 9.20 & 12.3 & 148 \\
\hline 0 & 1,015 & & 1215 & 14.8 & 3.41 & 350 & 13.2 & 3.49 & 8.94 & 11.3 & 144 \\
\hline 0 & 1,072 & & 1206 & 13.3 & 3.45 & 312 & 12.0 & 3.16 & 7.94 & 10.4 & 136 \\
\hline 0 & 1,132 & & 1151 & 12.1 & 3.62 & 208 & 9.55 & 2.39 & 5.34 & 6.11 & 104 \\
\hline 0 & 1,161 & & 1142 & 11.9 & 3.62 & 194 & 9.27 & 2.28 & 5.10 & 6.09 & 104 \\
\hline 0 & 1,232 & & 1124 & 11.8 & 3.65 & 195 & 9.00 & 2.20 & 4.90 & 5.64 & 95.0 \\
\hline 0 & 1,292 & & 1117 & 10.6 & 3.53 & 197 & 8.86 & 2.15 & 4.83 & 5.50 & 71.2 \\
\hline 0 & 1,352 & & 1110 & 10.6 & 3.84 & 187 & 8.79 & 2.17 & 4.75 & 5.39 & 72.3 \\
\hline 0 & 1,402 & & 1055 & 9.3 & 3.79 & 175 & 8.62 & 2.34 & 5.17 & 5.24 & 69.2 \\
\hline 0 & 1,462 & & 1043 & 9.0 & 3.82 & 165 & 8.79 & 2.17 & 4.68 & 5.03 & 67.9 \\
\hline 0 & 1,522 & & 1035 & 10.2 & 3.80 & 164 & 8.81 & 2.15 & 4.62 & 4.77 & 67.5 \\
\hline 0 & 1,582 & & 1030 & 13.8 & 3.79 & 152 & 8.49 & 2.04 & 4.25 & 4.51 & 67.8 \\
\hline 0 & 1,642 & & 1022 & 9.5 & 3.73 & 164 & 8.53 & 2.02 & 4.19 & 4.33 & 63.2 \\
\hline 0 & 1,702 & FC-4 & 1008 & 8.5 & 3.65 & 160 & 8.50 & 2.07 & 4.18 & 4.16 & 83.6 \\
\hline 0 & 1,750 & & 1003 & 7.9 & 4.00 & 150 & 8.43 & 2.04 & 4.05 & 3.90 & 76.9 \\
\hline 0 & 1,816 & & 950 & 7.5 & 4.21 & 156 & 11.5 & 2.81 & 3.82 & 3.58 & 77.9 \\
\hline 0 & 1,876 & & 940 & 7.0 & 4.14 & 152 & 12.8 & 3.34 & 4.15 & 3.34 & 77.4 \\
\hline 0 & 1,936 & & 925 & 6.6 & 4.51 & 157 & 13.3 & 3.45 & 4.20 & 3.18 & 76.9 \\
\hline 0 & 2,000 & & 920 & 6.2 & 4.54 & 150 & 13.4 & 3.48 & 3.81 & 3.05 & 76.8 \\
\hline 0 & 2,115 & & 912 & 5.9 & 4.66 & 148 & 13.2 & 3.37 & 3.73 & 2.89 & 89.0 \\
\hline 0 & 2,235 & & 905 & 6.1 & 5.90 & 136 & 14.9 & 3.49 & 3.29 & 2.67 & 52.7 \\
\hline 0 & 2,355 & & 855 & 6.6 & 5.61 & 135 & 14.9 & 3.49 & 3.29 & 2.42 & 48.0 \\
\hline
\end{tabular}


Table 4. Characteristics of water and concentrations of major ions in water from synoptic-sampling sites, Fisher Creek, Montana, August 19, 1997-Continued

\begin{tabular}{crlrrrrrrrrr}
\hline Trib & Distance & EPA name & Time & Temp & pH & \multicolumn{1}{c}{$\mathrm{K}_{\text {sc }}$} & Calcium & Magnesium & Sodium & Chloride & Sulfate \\
\hline 1 & 21 & & 1610 & 11.9 & 4.90 & 38 & 3.04 & .27 & 1.09 & 0.04 & 14.7 \\
1 & 263 & F-8A & 1535 & 2.9 & 3.00 & 1,402 & 58.1 & 17.3 & 4.13 & .11 & 601 \\
1 & 292 & FCT-11 & 1523 & 16.2 & 3.76 & 132 & 7.00 & 1.53 & 1.01 & .00 & 64.1 \\
1 & 397 & & 1510 & 11.5 & 3.97 & 93 & 7.93 & 1.60 & 1.08 & .04 & 49.9 \\
1 & 492 & & 1450 & 12.7 & 6.22 & 109 & 13.2 & 2.78 & 2.15 & .18 & 33.9 \\
1 & 550 & & 1442 & 8.5 & 5.70 & 75 & 8.05 & 1.47 & 2.19 & .20 & 21.5 \\
1 & 599 & & 1425 & 19.7 & 6.33 & 66 & 5.99 & 1.00 & 3.65 & .04 & 15.7 \\
1 & 645 & & 1420 & 17.5 & 3.27 & 310 & 10.1 & 2.96 & 3.09 & .29 & 114 \\
1 & 666 & & 1410 & 11.9 & 3.61 & 289 & 11.3 & 4.20 & 4.54 & .09 & 123 \\
1 & 670 & & 1403 & 19.9 & 3.75 & 130 & 4.54 & 1.77 & 3.33 & .06 & 68.4 \\
1 & 699 & & 1347 & 16.2 & 5.78 & 47 & 4.48 & .85 & 1.78 & .06 & 17.0 \\
1 & 729 & & 1337 & 14.1 & 6.49 & 42 & 4.60 & .80 & 1.70 & .06 & 5.71 \\
1 & 786 & & 1325 & 13.8 & 4.44 & 47 & 2.09 & .74 & 1.86 & .04 & 26.7 \\
1 & 1,034 & FCT-1 & 1210 & 13.6 & 6.25 & 37 & 3.43 & 1.06 & 1.30 & .06 & 22.4 \\
1 & 1,103 & FCT-2 & 1200 & 10.0 & 6.45 & 46 & 5.53 & 1.07 & .89 & .04 & 9.43 \\
1 & 1,134 & FCT-14 & 1146 & 11.5 & 3.85 & 84 & 3.70 & 1.09 & 1.73 & .05 & 47.9 \\
1 & 1,172 & & 1128 & 10.1 & 6.37 & 39 & 4.83 & .68 & 1.21 & .03 & 10.3 \\
1 & 1,394 & & 1100 & 8.4 & 6.16 & 29 & 2.85 & .56 & 1.60 & .14 & 2.76 \\
1 & 1,412 & FCT-15 & 1050 & 7.7 & 6.37 & 81 & 11.9 & 1.54 & .87 & .00 & 14.0 \\
1 & 1,756 & FCT-4 & 1000 & 8.3 & 6.74 & 241 & 32.6 & 8.08 & 1.59 & .02 & 101 \\
1 & 1,834 & & 945 & 7.9 & 6.76 & 350 & 44.2 & 15.1 & 6.52 & .08 & 138 \\
1 & 1,917 & & 930 & 7.8 & 6.27 & 169 & 23.4 & 4.68 & 1.05 & .03 & 69.5 \\
1 & 2,116 & FCT-13 & 910 & 5.6 & 7.20 & 164 & 25.9 & 4.21 & .96 & .11 & 35.9 \\
\hline
\end{tabular}


Table 5. Metal concentrations in samples from Fisher Creek, Montana, August 19, 1997

[All concentrations in micrograms per liter, Trib, $0=$ stream sites, $1=$ inflow site, $9=$ field blank; Distance, distance from injection site, in meters]

\begin{tabular}{|c|c|c|c|c|c|c|c|c|c|c|c|c|c|c|c|}
\hline Trib & Distance & $\begin{array}{l}\text { Aluminum, } \\
\text { filtered }\end{array}$ & $\begin{array}{c}\text { Aluminum, } \\
\text { total }\end{array}$ & $\begin{array}{l}\text { Arsenic, } \\
\text { filtered }\end{array}$ & $\begin{array}{c}\text { Arsenic, } \\
\text { total }\end{array}$ & $\begin{array}{l}\text { Barium, } \\
\text { filtered }\end{array}$ & $\begin{array}{c}\text { Barium, } \\
\text { total }\end{array}$ & $\begin{array}{l}\text { Cadmium, } \\
\text { filtered }\end{array}$ & $\begin{array}{c}\text { Cadmium, } \\
\text { total }\end{array}$ & $\begin{array}{l}\text { Copper, } \\
\text { filtered }\end{array}$ & $\begin{array}{c}\text { Copper, } \\
\text { total }\end{array}$ & $\begin{array}{l}\text { Iron, } \\
\text { filtered }\end{array}$ & $\begin{array}{l}\text { Iron, } \\
\text { total }\end{array}$ & $\begin{array}{l}\text { Lead, } \\
\text { filtered }\end{array}$ & $\begin{array}{l}\text { Lead, } \\
\text { total }\end{array}$ \\
\hline 0 & 10 & 1,380 & 1,410 & $<3$ & $<3$ & 37 & 40 & $<3$ & $<3$ & 726 & 726 & 117 & 192 & $<2$ & 3 \\
\hline 0 & 60 & 1,260 & 1,250 & $<3$ & $<3$ & 39 & 38 & $<3$ & $<3$ & 595 & 570 & 214 & 235 & 3 & 5 \\
\hline 0 & 120 & 1,550 & 1,540 & $<3$ & $<3$ & 58 & 56 & $<3$ & $<3$ & 664 & 646 & 120 & 139 & 6 & 7 \\
\hline 0 & 180 & 2,330 & 2,380 & $<3$ & $<3$ & 85 & 85 & $<3$ & $<3$ & 970 & 973 & 70 & 102 & 7 & 9 \\
\hline 0 & 257 & 3,210 & 3,170 & $<3$ & $<3$ & 107 & 105 & $<3$ & $<3$ & $1,230^{\circ}$ & 1,190 & 51 & 64 & 8 & 9 \\
\hline 0 & 280 & 10,400 & 10,200 & 6 & 4 & 40 & 40 & $<3$ & $<3$ & 4,070 & 3,990 & 45,500 & 45,700 & 23 & 25 \\
\hline 0 & 330 & 4,900 & 5,010 & $<3$ & $<3$ & 36 & 38 & $<3$ & $<3$ & 1,650 & 1,640 & 14,400 & 17,100 & 8 & 10 \\
\hline 0 & 390 & 4,910 & 4,820 & $<3$ & $<3$ & 37 & 36 & $<3$ & $<3$ & 1,650 & 1,590 & 13,500 & 15,700 & 9 & 10 \\
\hline 0 & 430 & 4,800 & 4,640 & $<3$ & $<3$ & 36 & 35 & $<3$ & $<3$ & 1,610 & 1,510 & 14,100 & 14,400 & 9 & 10 \\
\hline 0 & 482 & 4,560 & 4,450 & $<3$ & $<3$ & 36 & 35 & $<3$ & $<3$ & 1,530 & 1,450 & 12,700 & 13,200 & 8 & 10 \\
\hline 0 & 542 & 4,170 & 4,090 & $<3$ & $<3$ & 33 & 33 & $<3$ & $<3$ & 1,400 & 1,330 & 11,200 & 11,500 & 8 & 9 \\
\hline 0 & 567 & 3,880 & 3,980 & $<3$ & $<3$ & 32 & 34 & $<3$ & $<3$ & 1,300 & 1,320 & 9,970 & 10,400 & 7 & 7 \\
\hline 0 & 618 & 3,810 & 4,090 & $<3$ & $<3$ & 32 & 35 & $<3$ & $<3$ & 1,270 & 1,350 & 8,900 & 10,100 & 6 & 7 \\
\hline 0 & 659 & 3,620 & 3,730 & $<3$ & $<3$ & 30 & 31 & $<3$ & $<3$ & 1,210 & 1,260 & 7,590 & 8,520 & 6 & 7 \\
\hline 0 & 692 & 3,550 & 3,690 & $<3$ & $<3$ & 29 & 31 & $<3$ & $<3$ & 1,230 & 1,270 & 7,080 & 7,620 & 7 & 7 \\
\hline 0 & 725 & 3,460 & 3,690 & $<3$ & $<3$ & 28 & 31 & $<3$ & $<3$ & 1,190 & 1,260 & 6,830 & 7,410 & 6 & 7 \\
\hline 0 & 802 & 3,230 & 3,360 & $<3$ & $<3$ & 27 & 30 & $<3$ & $<3$ & 1,120 & 1,150 & 6,110 & 6,500 & 5 & 7 \\
\hline 0 & 840 & 3,180 & 3,340 & $<3$ & $<3$ & 27 & 29 & $<3$ & $<3$ & 1,100 & 1,150 & 5,940 & 6,340 & 5 & 4 \\
\hline 0 & 900 & 3,110 & 3,230 & $<3$ & $<3$ & 27 & 29 & $<3$ & $<3$ & 1,070 & 1,120 & 5,570 & 5,920 & 5 & 5 \\
\hline 0 & 955 & 3,000 & 3,160 & $<3$ & $<3$ & 26 & 28 & $<3$ & $<3$ & 1,040 & 1,090 & 5,170 & 5,610 & 5 & 6 \\
\hline 0 & 955 & 3,050 & 3,160 & $<3$ & $<3$ & 27 & 29 & $<3$ & $<3$ & 1,050 & 1,080 & 5,310 & 5,570 & 5 & 6 \\
\hline 0 & 1,015 & 3,000 & 3,160 & 10 & $<3$ & 26 & 29 & $<3$ & $<3$ & 1,040 & 1,080 & 5,170 & 5,540 & 5 & 5 \\
\hline 0 & 1,072 & 2,620 & 2,790 & 9 & $<3$ & 28 & 30 & $<3$ & $<3$ & 921 & 970 & 4,400 & 4,760 & 4 & 5 \\
\hline 0 & 1,132 & 1,670 & 1,740 & 8 & $<3$ & 21 & 23 & $<3$ & $<3$ & 580 & 606 & 2,710 & 2,940 & $<2$ & 3 \\
\hline 0 & 1,161 & 1,610 & 1,800 & 8 & $<3$ & 22 & 25 & $<3$ & $<3$ & 548 & 614 & 2,520 & 2,860 & 2 & 3 \\
\hline 0 & 1,232 & 1,540 & 1,830 & 8 & $<3$ & 21 & 25 & $<3$ & $<3$ & 528 & 578 & 2,390 & 2,690 & $<2$ & 4 \\
\hline 0 & 1,292 & 1,520 & 1,660 & 9 & $<3$ & 21 & 23 & $<3$ & $<3$ & 510 & 561 & 2,270 & 2,560 & $<2$ & 2 \\
\hline 0 & 1,352 & 1,480 & 1,600 & 9 & $<3$ & 20 & 23 & $<3$ & $<3$ & 500 & 538 & 2,200 & 2,390 & $<2$ & 3 \\
\hline 0 & 1,402 & 1,590 & 1,620 & 7 & $<3$ & 23 & 24 & $<3$ & $<3$ & 537 & 555 & 2,260 & 2,440 & $<2$ & $<2$ \\
\hline 0 & 1,462 & 1,380 & 1,520 & 11 & $<3$ & 22 & 23 & $<3$ & $<3$ & 477 & 493 & 1,910 & 2,200 & $<2$ & 2 \\
\hline 0 & 1,522 & 1,370 & 1,390 & 10 & $<3$ & 22 & 21 & $<3$ & $<3$ & 474 & 461 & 1,810 & 2,000 & $<2$ & 3 \\
\hline 0 & 1,582 & 1,310 & 1,390 & $<3$ & $<3$ & 21 & 22 & $<3$ & $<3$ & 437 & 473 & 1,660 & 1,970 & $<2$ & 2 \\
\hline 0 & 1,642 & 1,320 & 1,380 & $<3$ & $<3$ & 21 & 21 & $<3$ & $<3$ & 440 & 461 & 1,590 & 2,000 & $<2$ & 3 \\
\hline 0 & 1,702 & 1,320 & 1,380 & $<3$ & $<3$ & 21 & 22 & $<3$ & $<3$ & 439 & 455 & 1,580 & 1,840 & $<2$ & 3 \\
\hline 0 & 1,750 & 1,270 & 1,380 & $<3$ & $<3$ & 20 & 22 & $<3$ & $<3$ & 427 & 464 & 1,480 & 1,800 & $<2$ & 3 \\
\hline 0 & 1,816 & 1,120 & 1,270 & $<3$ & $<3$ & 21 & 22 & $<3$ & $<3$ & 374 & 396 & 997 & 1,550 & $<2$ & 2 \\
\hline 0 & 1,876 & 1,120 & 1,160 & $<3$ & $<3$ & 23 & 22 & $<3$ & $<3$ & 380 & 375 & 766 & 1,470 & $<2$ & 3 \\
\hline 0 & 1,936 & 1,090 & 1,100 & $<3$ & $<3$ & 23 & 24 & $<3$ & $<3$ & 370 & 366 & 703 & 1,390 & $<2$ & 4 \\
\hline 0 & 2,000 & 1,040 & 1,050 & $<3$ & $<3$ & 25 & 22 & $<3$ & $<3$ & 364 & 346 & 627 & 1,290 & $<2$ & 3 \\
\hline 0 & 2,115 & 1,010 & 1,050 & $<3$ & $<3$ & 25 & 22 & $<3$ & $<3$ & 357 & 342 & 554 & 1,250 & $<2$ & 3 \\
\hline 0 & 2,235 & 89 & 887 & $<3$ & $<3$ & 27 & 25 & $<3$ & $<3$ & 271 & 280 & 397 & 1,020 & $<2$ & 3 \\
\hline 0 & 2,355 & 61 & 878 & $<3$ & $<3$ & 27 & 26 & $<3$ & $<3$ & 253 & 284 & 355 & 1,000 & $<2$ & $<2$ \\
\hline 1 & 21 & 213 & 228 & $<3$ & $<3$ & 25 & 24 & $<3$ & $<3$ & $<4$ & $<4$ & $<14$ & 38 & 3 & 5 \\
\hline 1 & 263 & 14,100 & 13,400 & 6 & 6 & 9 & 7 & $<3$ & $<3$ & 5,550 & 5,290 & 69,400 & 67,600 & 33 & 33 \\
\hline 1 & 292 & 1,950 & 2,230 & $<3$ & $<3$ & 35 & 36 & $<3$ & $<3$ & 365 & 363 & 1,750 & 2,400 & $<2$ & 4 \\
\hline 1 & 397 & 155 & 199 & $<3$ & $<3$ & 17 & 17 & $<3$ & $<3$ & 43 & 41 & 61 & 99 & $<2$ & $<2$ \\
\hline 1 & 492 & $<35$ & 62 & $<3$ & $<3$ & 13 & 12 & $<3$ & $<3$ & $<4$ & $<4$ & $<14$ & $<14$ & $<2$ & $<2$ \\
\hline 1 & 550 & 51 & 105 & $<3$ & $<3$ & 11 & 10 & $<3$ & $<3$ & 10 & $<4$ & 22 & 28 & $<2$ & $<2$ \\
\hline 1 & 599 & $<35$ & 105 & $<3$ & $<3$ & 13 & 14 & $<3$ & $<3$ & 5 & 20 & 54 & 283 & $<2$ & $<2$ \\
\hline 1 & 645 & 3,280 & 3,400 & $<3$ & $<3$ & 19 & 20 & $<3$ & $<3$ & 1,200 & 1,220 & 2,600 & 2,650 & 4 & 5 \\
\hline 1 & 666 & 3,160 & 3,440 & $<3$ & $<3$ & 13 & 15 & $<3$ & $<3$ & 1,940 & 2,070 & 5,990 & 16,900 & $<2$ & $<2$ \\
\hline 1 & 670 & 2,280 & 2,350 & $<3$ & $<3$ & 28 & 30 & $<3$ & $<3$ & 1,340 & 1,360 & 384 & 1,010 & $<2$ & $<2$ \\
\hline 1 & 699 & 49 & 88 & $<3$ & $<3$ & 8 & 8 & $<3$ & $<3$ & 7 & 10 & 39 & 122 & $<2$ & $<2$ \\
\hline 1 & 729 & $<35$ & 69 & $<3$ & $<3$ & 8 & 10 & $<3$ & $<3$ & 6 & 12 & $<14$ & 72 & $<2$ & 2 \\
\hline 1 & 786 & 353 & 429 & $<3$ & $<3$ & 52 & 55 & $<3$ & $<3$ & 323 & 346 & $<14$ & 36 & $<2$ & $<2$ \\
\hline 1 & 1,034 & $<35$ & 120 & 11 & $<3$ & 46 & 49 & $<3$ & $<3$ & 182 & 208 & $<14$ & $<14$ & $<2$ & $<2$ \\
\hline 1 & 1,103 & $<35$ & 100 & 9 & $<3$ & 11 & 13 & $<3$ & $<3$ & 4 & 8 & $<14$ & 24 & $<2$ & $<2$ \\
\hline 1 & 1,134 & 1,390 & 1,590 & 8 & $<3$ & 35 & 39 & $<3$ & $<3$ & 375 & 403 & 25 & 36 & $<2$ & $<2$ \\
\hline 1 & 1,172 & $<35$ & 118 & 9 & $<3$ & 10 & 12 & $<3$ & $<3$ & $<4$ & 5 & $<14$ & 61 & $<2$ & $<2$ \\
\hline 1 & 1,394 & $<35$ & 92 & 10 & $<3$ & 8 & 10 & $<3$ & $<3$ & $<4$ & 5 & $<14$ & 58 & $<2$ & $<2$ \\
\hline 1 & 1,412 & $<35$ & 46 & 8 & $<3$ & $19^{\circ}$ & 18 & $<3$ & $<3$ & $<4$ & $<4$ & $<14$ & $<14$ & $<2$ & $<2$ \\
\hline 1 & 1,756 & $<35$ & 62 & $<3$ & $<3$ & 26 & 28 & $<3$ & $<3$ & $<4$ & $<4$ & $<14$ & $<14$ & $<2$ & $<2$ \\
\hline 1 & 1,834 & $<35$ & 61 & $<3$ & $<3$ & 32 & 34 & $<3$ & $<3$ & 4 & 4 & $<14$ & $<14$ & $<2$ & $<2$ \\
\hline 1 & 1,917 & $<35$ & 51 & $<3$ & $<3$ & 32 & 31 & $<3$ & $<3$ & $<4$ & $<4$ & $<14$ & $<14$ & $<2$ & $<2$ \\
\hline 1 & 2,116 & 41 & 35 & $<3$ & $<3$ & 47 & 44 & $<3$ & $<3$ & $<4$ & $<4$ & $<14$ & $<14$ & $<2$ & $<2$ \\
\hline 9 & Field blank & $<35$ & 62 & $<3$ & $<3$ & $<1$ & $<1$ & $<3$ & $<3$ & $<4$ & $<4$ & $<14$ & $<14$ & $<2$ & $<2$ \\
\hline 9 & Field blank & $<35$ & 76 & 8 & $<3$ & $<1$ & $<1$ & $<3$ & $<3$ & $<4$ & $<4$ & $<14$ & $<14$ & $<2$ & $<2$ \\
\hline
\end{tabular}




\begin{tabular}{|c|c|c|c|c|c|c|c|c|c|c|c|c|c|c|}
\hline Trib & Distance & $\begin{array}{l}\text { Manganese, } \\
\text { fittered }\end{array}$ & $\begin{array}{c}\text { Manganese, } \\
\text { total }\end{array}$ & $\begin{array}{l}\text { Nickel, } \\
\text { filtered }\end{array}$ & $\begin{array}{l}\text { Nickel, } \\
\text { total }\end{array}$ & $\begin{array}{l}\text { Selenium, } \\
\text { filtered }\end{array}$ & $\begin{array}{l}\text { Selenium, } \\
\text { total }\end{array}$ & $\begin{array}{l}\text { Silver, } \\
\text { filtered }\end{array}$ & $\begin{array}{l}\text { Silver, } \\
\text { total }\end{array}$ & $\begin{array}{l}\text { Thallum, } \\
\text { filtered }\end{array}$ & $\begin{array}{l}\text { Thalium, } \\
\text { total }\end{array}$ & $\begin{array}{l}\text { Vanadium, } \\
\text { filtered }\end{array}$ & $\begin{array}{l}\text { Zinc, } \\
\text { filtered }\end{array}$ & $\begin{array}{l}\text { Zinc, } \\
\text { total }\end{array}$ \\
\hline 0 & 10 & 43 & 44 & 6 & 23 & $<3$ & $<3$ & $<4$ & $<4$ & 7 & $<4$ & $<4$ & 29 & 50 \\
\hline 0 & 60 & 77 & 74 & 7 & 26 & $<3$ & $<3$ & 5 & $<4$ & 6 & $<4$ & $<4$ & 32 & 90 \\
\hline 0 & 120 & 82 & 80 & $<6$ & 13 & $<3$ & $<3$ & $<4$ & $<4$ & 6 & $<4$ & $<4$ & 33 & 49 \\
\hline 0 & 180 & 100 & 104 & $<6$ & 16 & $<3$ & $<3$ & $<4$ & $<4$ & $<4$ & $<4$ & $<4$ & 40 & 71 \\
\hline 0 & 257 & 121 & 118 & $<6$ & 15 & $<3$ & 4 & $<4$ & $<4$ & $<4$ & $<4$ & $<4$ & 48 & 54 \\
\hline 0 & 280 & 58 & 63 & $<3$ & 5 & $<4$ & $<4$ & $<4$ & $<4$ & 6 & 6 & $<4$ & 465 & 445 \\
\hline 0 & 330 & 1,500 & 1,490 & 28 & 36. & $<3$ & 4 & $<4$ & $<4$ & $<4$ & $<4$ & $<4$ & 190 & 208 \\
\hline 0 & 390 & 1,500 & 1,440 & 31 & 28 & $<3$ & $<3$ & 6 & $<4$ & 6 & 4 & $<4$ & 191 & 248 \\
\hline 0 & 430 & 1,470 & 1,380 & 29 & 31 & $<3$ & 6 & $<4$ & $<4$ & $<4$ & $<4$ & $<4$ & 186 & 199 \\
\hline 0 & 482 & 1.400 & 1,320 & 22 & 29 & $<3$ & 4 & $<4$ & $<4$ & 4 & $<4$ & $<4$ & 180 & 183 \\
\hline 0 & 542 & 1,290 & 1,200 & 25 & 28 & $<3$ & 3 & $<4$ & $<4$ & $<4$ & $<4$ & $<4$ & 168 & 174 \\
\hline 0 & 567 & 1.190 & 1,160 & 23 & 22 & $<3$ & $<3$ & $<4$ & $<4$ & 5 & $<4$ & $<4$ & 156 & 178 \\
\hline 0 & 618 & 1,140 & 1,180 & 20 & 22 & $<3$ & $<3$ & $<4$ & $<4$ & 4 & $<4$ & $<4$ & 151 & 209 \\
\hline 0 & 659 & 992 & 999 & 22 & 22 & $<3$ & $<3$ & $<4$ & $<4$ & $<4$ & $<4$ & $<4$ & 151 & 176 \\
\hline 0 & 692 & 961 & 966 & 18 & 26 & $<3$ & $<3$ & $<4$ & $<4$ & $<4$ & $<4$ & $<4$ & 150 & 161 \\
\hline 0 & 725 & 932 & 951 & 18 & 18 & $<3$ & $<3$ & $<4$ & $<4$ & $<4$ & $<4$ & $<4$ & 144 & 171 \\
\hline 0 & 802 & 874 & 868 & 17 & 17 & $<3$ & $<3$ & $<4$ & $<4$ & $<4$ & $<4$ & $<4$ & 137 & 154 \\
\hline 0 & 840 & 863 & 860 & 19 & 15 & $<3$ & $<3$ & $<4$ & $<4$ & $<4$ & $<4$ & $<4$ & 134 & 158 \\
\hline 0 & 900 & 838 & 837 & 14 & 16 & $<3$ & $<3$ & $<4$ & $<4$ & $<4$ & $<4$ & $<4$ & 132 & 141 \\
\hline 0 & 955 & 810 & 812 & 17 & 19 & $<3$ & $<3$ & $<4$ & $<4$ & $<4$ & $<4$ & $<4$ & 129 & 150 \\
\hline 0 & 955 & 822 & 805 & 11 & 14 & $<3$ & $<3$ & $<4$ & $<4$ & $<4$ & $<4$ & $<4$ & 130 & 143 \\
\hline 0 & 1,015 & 802 & 802 & 16 & 14 & $<3$ & $<3$ & 5 & $<4$ & 7 & $<4$ & $<4$ & 128 & 138 \\
\hline 0 & 1,072 & 701 & 707 & 12 & 14 & $<3$ & $<3$ & $<4$ & $<4$ & $<4$ & $<4$ & $<4$ & 113 & 138 \\
\hline 0 & 1,132 & 443 & 442 & $<6$ & 15 & $<3$ & $<3$ & $<4$ & $<4$ & 5 & $<4$ & $<4$ & 73 & 78 \\
\hline 0 & 1,161 & 421 & 437 & $<6$ & 7 & $<3$ & $<3$ & $<4$ & $<4$ & $<4$ & $<4$ & $<4$ & 71 & 106 \\
\hline 0 & 1,232 & 401 & 417 & $<6$ & 8 & $<3$ & $<3$ & $<4$ & $<4$ & 7 & $<4$ & $<4$ & 69 & 86 \\
\hline 0 & 1,292 & 391 & 404 & 9 & 15 & $<3$ & $<3$ & $<4$ & $<4$ & $<4$ & $<4$ & $<4$ & 66 & 78 \\
\hline 0 & 1,352 & 383 & 390 & 9 & 14 & $<3$ & $<3$ & 4 & $<4$ & 6 & $<4$ & $<4$ & 67 & 75 \\
\hline 0 & 1,402 & 390 & 397 & 6 & 12 & $<3$ & $<3$ & $<4$ & $<4$ & $<4$ & $<4$ & 6 & 69 & 87 \\
\hline 0 & 1,462 & 345 & 357 & $<6$ & $<6$ & $<3$ & $<3$ & $<4$ & $<4$ & 5 & $<4$ & $<4$ & 59 & 93 \\
\hline 0 & 1,522 & 341 & 339 & $<6$ & 8 & $<3$ & $<3$ & $<4$ & $<4$ & $<4$ & $<4$ & $<4$ & 60 & 77 \\
\hline 0 & 1,582 & 325 & 345 & 8 & $<6$ & $<3$ & $<3$ & $<4$ & $<4$ & 5 & $<4$ & $<4$ & 55 & 70 \\
\hline 0 & 1,642 & 327 & 337 & $<6$ & 11 & $<3$ & $<3$ & $<4$ & $<4$ & $<4$ & $<4$ & $<4$ & 55 & 66 \\
\hline 0 & 1,702 & 325 & 333 & 14 & 12 & 3 & $<3$ & $<4$ & $<4$ & 4 & $<4$ & $<4$ & 55 & 76 \\
\hline 0 & 1,750 & 317 & 338 & 11 & 15 & $<3$ & $<3$ & $<4$ & $<4$ & 5 & $<4$ & $<4$ & 54 & 66 \\
\hline 0 & 1,816 & 281 & 288 & 9 & 7 & $<3$ & $<3$ & $<4$ & $<4$ & 5 & $<4$ & $<4$ & 53 & 79 \\
\hline 0 & 1,876 & 277 & 277 & $<6$ & 10 & $<3$ & $<3$ & $<4$ & 4 & $<4$ & $<4$ & $<4$ & 54 & 62 \\
\hline 0 & 1,936 & 272 & 268 & 7 & 8 & $<3$ & $<3$ & $<4$ & $<4$ & $<4$ & $<4$ & $<4$ & 54 & 71 \\
\hline 0 & 2,000 & 266 & 254 & $<6$ & 7 & $<3$ & $<3$ & $<4$ & $<4$ & 6 & $<4$ & $<4$ & 51 & 60 \\
\hline 0 & 2,115 & 259 & 253 & $<6$ & 7 & $<3$ & $<3$ & $<4$ & $<4$ & $<4$ & $<4$ & $<4$ & 51 & 69 \\
\hline 0 & 2,235 & 219 & 208 & $<6$ & 13 & $<3$ & $<3$ & $<4$ & $<4$ & $<4$ & $<4$ & $<4$ & 43 & 57 \\
\hline 0 & 2,355 & 218 & 211 & $<6$ & $<6$ & $<3$ & $<3$ & $<4$ & $<4$ & 5 & $<4$ & $<4$ & 44 & 53 \\
\hline 1 & 21 & 38 & 38 & 9 & 9 & $<3$ & 3 & 7 & $<4$ & $<4$ & $<4$ & $<4$ & 29 & 59 \\
\hline 1 & 263 & 3,860 & 3,790 & 58 & 63 & $<3$ & 5 & $<4$ & $<4$ & 6 & 6 & $<4$ & 465 & 445 \\
\hline 1 & 292 & 1,500 & 1,440 & 31 & 28 & $<3$ & $<3$ & 6 & $<4$ & 6 & $<4$ & $<4$ & 191 & 248 \\
\hline 1 & 397 & 34 & 35 & $<6$ & $<6$ & $<3$ & $<3$ & $<4$ & $<4$ & $<4$ & $<4$ & $<4$ & 14 & 104 \\
\hline 1 & 492 & $<2$ & 4 & 8 & 9 & $<3$ & $<3$ & $<4$ & $<4$ & $<4$ & $<4$ & $<4$ & 10 & 23 \\
\hline 1 & 550 & 8 & 5 & 8 & $<6$ & $<3$ & $<3$ & $<4$ & $<4$ & $<4$ & $<4$ & $<4$ & 6 & 47 \\
\hline 1 & 599 & 10 & 10 & $<6$ & $<6$ & $<3$ & $<3$ & $<4$ & $<4$ & $<4$ & $<4$ & $<4$ & 8 & 41 \\
\hline 1 & 645 & 452 & 451 & 17 & 21 & $<3$ & $<3$ & $<4$ & $<4$ & $<4$ & $<4$ & $<4$ & 165 & 199 \\
\hline 1 & 666 & 610 & 629 & 16 & 25 & $<3$ & $<3$ & $<4$ & $<4$ & $<4$ & $<4$ & $<4$ & 162 & 195 \\
\hline 1 & 670 & 243 & 233 & 19 & 13 & $<3$ & $<3$ & $<4$ & $<4$ & $<4$ & $<4$ & 8 & 84 & 108 \\
\hline 1 & 699 & 13 & 14 & $<6$ & $<6$ & $<3$ & $<3$ & $<4$ & $<4$ & $<4$ & $<4$ & $<4$ & $<3$ & 12 \\
\hline 1 & 729 & $<2$ & $<2$ & $<6$ & $<6$ & $<3$ & $<3$ & $<4$ & $<4$ & $<4$ & $<4$ & $<4$ & 13 & 40 \\
\hline 1 & 786 & 38 & 37 & $<6$ & 10 & $<3$ & $<3$ & $<4$ & $<4$ & $<4$ & $<4$ & $<4$ & 13 & 44 \\
\hline 1 & 1,034 & 5 & 6 & $<6$ & $<6$ & $<3$ & $<3$ & $<4$ & $<4$ & 5 & $<4$ & $<4$ & 11 & 25 \\
\hline 1 & 1,103 & $<2$ & 2 & $<6$ & $<6$ & $<3$ & $<3$ & $<4$ & $<4$ & $<4$ & $<4$ & $<4$ & 4 & 35 \\
\hline 1 & 1,134 & 218 & 223 & $<6$ & 6 & $<3$ & $<3$ & $<4$ & $<4$ & 5 & $<4$ & $<4$ & 75 & 99 \\
\hline 1 & 1,394 & $<2$ & 2 & $<6$ & $<6$ & $<3$ & $<3$ & $<4$ & $<4$ & $<4$ & $<4$ & $<4$ & $<3$ & 16 \\
\hline 1 & 1.172 & $<2$ & $<2$ & $<6$ & $<6$ & $<3$ & $<3$ & $<4$ & $<4$ & $<4$ & $<4$ & $<4$ & $<3$ & 32 \\
\hline 1 & 1,412 & $<2$ & $<2$ & $<6$ & $<6$ & $<3$ & $<3$ & $<4$ & $<4$ & $<4$ & $<4$ & $<4$ & $<3$ & 22 \\
\hline 1 & 1,756 & 5 & 6 & 7 & 11 & 3 & $<3$ & $<4$ & $<4$ & $<4$ & $<4$ & $<4$ & 51 & 63 \\
\hline 1 & 1,834 & $<2$ & $<2$ & $<6$ & $<6$ & $<3$ & $<3$ & $<4$ & 4 & 4 & $<4$ & $<4$ & 17 & 36 \\
\hline 1 & 1,917 & $<2$ & $<2$ & $<6$ & $<6$ & $<3$ & $<3$ & $<4$ & $<4$ & $<4$ & $<4$ & $<4$ & 5 & 18 \\
\hline 1 & 2,116 & $<2$ & $<2$ & $<6$ & $<6$ & 4 & $<3$ & $<4$ & $<4$ & 4 & $<4$ & $<4$ & $<3$ & 6 \\
\hline 9 & Field blank & $<2$ & $<2$ & $<6$ & $<6$ & $<3$ & $<3$ & $<4$ & $<4$ & $<4$ & $<4$ & $<4$ & $<3$ & 11 \\
\hline 9 & Field blank & $<2$ & $<2$ & $<6$ & $<6$ & $<3$ & $<3$ & $<4$ & $<4$ & $<4$ & $<4$ & $<4$ & $<3$ & 19 \\
\hline
\end{tabular}




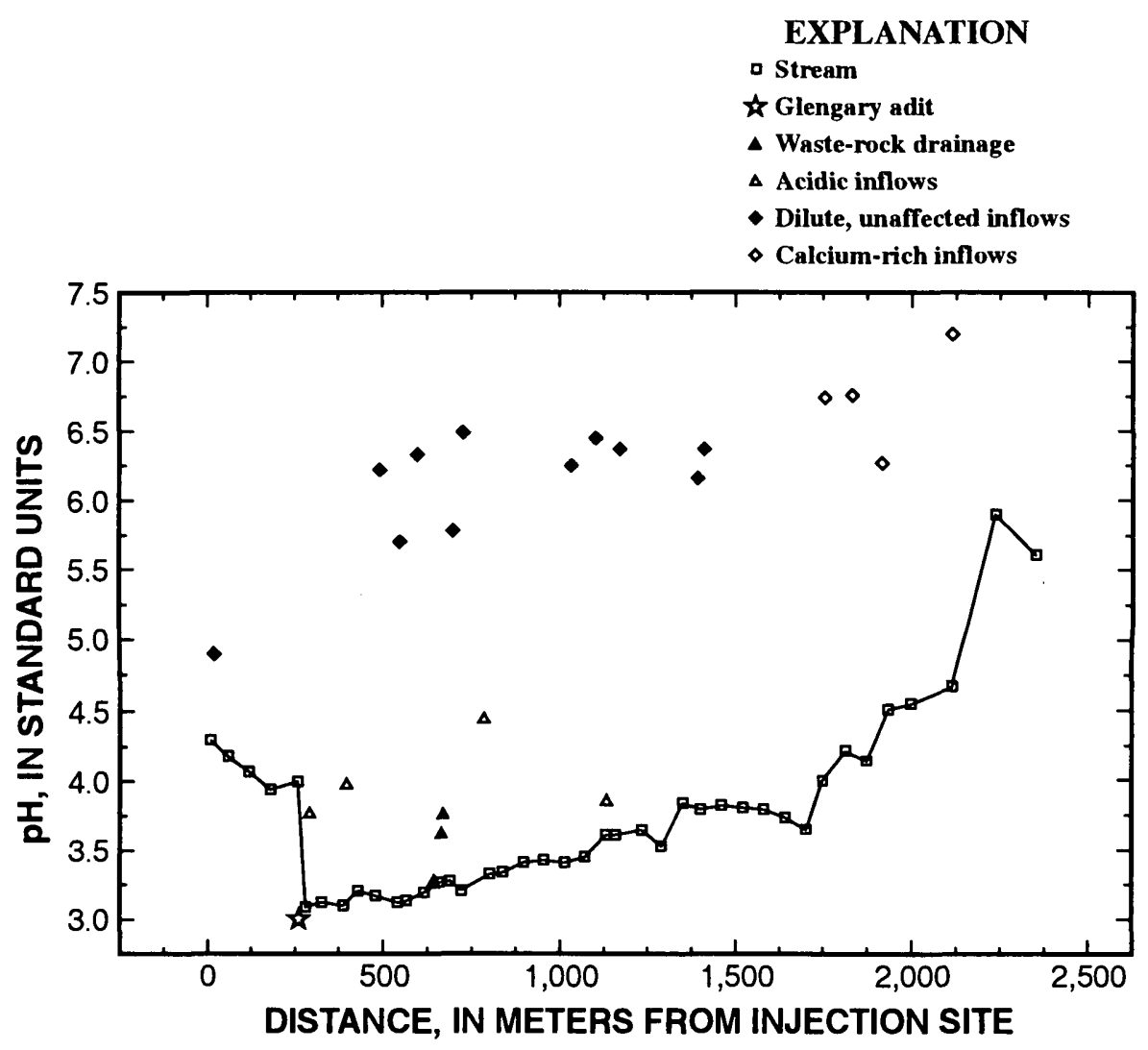

Figure 9. Variation of stream and inflow $\mathrm{pH}$ with distance from the injection site, Fisher Creek, Montana, August 19, 1997.

stantially, to a pH greater than 5.0, in response to the inflow of neutral $\mathrm{pH}$ water from the wetland and water draining carbonate rocks.

Inflow sampling sites were chosen to represent the range of chemistry that could be affecting the stream. The $\mathrm{pH}$ and chemistry of the 23 inflow samples indicated 5 groups of inflow chemistry (table 6). Three of these groups had $\mathrm{pH}$ values less than 5.0. The most unique inflow was from the Glengary adit; no other inflow was as acidic or had concentrations of metals that were as high. A second group of acidic inflows had substantially elevated metal concentrations and an average $\mathrm{pH}$ less than 4.0. All three inflows of this group drained the waste-rock pile just below the Glengary adit and entered Fisher Creek near $670 \mathrm{~m}$. A third group of inflows had a slightly less acidic $\mathrm{pH}$ and lower metal concentrations. They clearly contained metals, however, and may have represented more natural drainage of the porphyritic country rock. The sample from $21 \mathrm{~m}$, upstream from the Glengary adit, may have represented such natural acidic drainage.

Two groups of inflows had higher $\mathrm{pH}$. The first group included inflows that had low metal concentra- tions; these inflows appeared unaffected by mining ("Dilute catchment water," table 6). They occurred along much of the study reach between $492 \mathrm{~m}$ and $1,412 \mathrm{~m}$ and caused the gradual increase of $\mathrm{pH}$ from 3.08 at $280 \mathrm{~m}$ to 4.00 at $1,750 \mathrm{~m}$ (fig. 9). A second higher $\mathrm{pH}$ group occurred downstream from $1,750 \mathrm{~m}$ ("Calcium-rich," table 6). These inflows caused substantial increases in $\mathrm{pH}$ and a higher calcium (Ca) concentration. This group included the inflow from the Gold Dust Mine and inflows at the start of the wetland area.

\section{Stream Sites}

\section{Sources of Metals}

Metal content of the water in Fisher Creek was dominated by $\mathrm{Ca}$, iron ( $\mathrm{Fe})$, aluminum ( $\mathrm{Al}$ ), magnesium $(\mathrm{Mg})$, copper $(\mathrm{Cu})$, and zinc $(\mathrm{Zn})$. Natural and acidic weathering of the bedrock, particularly limestone that crops out in the watershed, produces $\mathrm{Ca}$ and $\mathrm{Mg}$. The high concentrations of $\mathrm{Al}$ result from the 
Table 6. Chemical characteristics of inflow groups from Fisher Creek, Montana, August 1997

[All concentrations are average values for filtered samples in the groups, in micrograms per liter, unless indicated]

\begin{tabular}{lcccccc}
\hline \multicolumn{1}{c}{ Inflow group } & $\begin{array}{c}\text { Glengary } \\
\text { adit }\end{array}$ & $\begin{array}{c}\text { Drainage from } \\
\text { waste-rock } \\
\text { pile }\end{array}$ & $\begin{array}{c}\text { Acidic water } \\
\text { catchment } \\
\text { water }\end{array}$ & $\begin{array}{c}\text { Calcium-rich } \\
\text { water }\end{array}$ & $\begin{array}{c}\text { Overall } \\
\text { average }\end{array}$ \\
\hline Number of samples & 1 & 3 & 5 & 10 & 4 & 23 \\
$\mathrm{pH}$, in standard units & 3.00 & 3.54 & 4.18 & 6.21 & 6.74 & 5.38 \\
$\begin{array}{l}\text { Specific conductance, in micro- } \\
\quad \text { siemens per centimeter at 25 }\end{array}$ & 1,402 & 243 & 79 & 57 & 231 & 175 \\
$\quad$ degrees Celsius & 584 & 101 & 39 & 15 & 85 & 69 \\
Sulfate & 58,100 & 8,647 & 4,752 & 6,486 & 31,525 & 12,990 \\
Calcium & 17,300 & 2,977 & 1,045 & 1,181 & 8,018 & 3,276 \\
Magnesium & 4,130 & 3,653 & 1,354 & 1,734 & 2,531 & 2,144 \\
Sodium & 14,100 & 2,907 & 812 & 38 & 36 & 1,192 \\
Aluminum & 5,550 & 1,493 & 222 & 23 & 4 & 495 \\
Copper & 69,400 & 2,991 & 373 & 21 & 14 & 3,500 \\
Iron & 5,740 & 435 & 115 & 5 & 3 & 334 \\
Manganese & 104 & 17 & 7 & 6 & 6 & 12 \\
Nickel & 679 & 137 & 35 & 7 & 19 & 61 \\
Zinc & & & & &
\end{tabular}

acidic attack on aluminosilicate minerals in the watershed. The source of the other metals is the oxidation of sulfide minerals in the mineralized rock, waste rock from mining, and tailings from processing. There were detectable levels of arsenic, barium, lead, nickel, selenium, thorium, and vanadium; each of these likely originated in mineralized rocks. There was no detectable concentration of cadmium. The major anion was $\mathrm{SO}_{4}$, which also originates from oxidation of pyrite and other sulfide minerals. Bicarbonate was important only at the most downstream sites, which were in the wetland area. During the injection, concentrations of $\mathrm{Na}$ and $\mathrm{Cl}$ were greater than the natural ions in the upper section of the study reach; under normal conditions, $\mathrm{Na}$ concentration would be only a few $\mathrm{mg} / \mathrm{L}$ and $\mathrm{Cl}$ concentration would be less than $1 \mathrm{mg} / \mathrm{L}$.

\section{Major Metals}

Comparison of metal-concentration patterns is facilitated by normalization using equation 3 (Bencala and McKnight, 1987). Each of the metals showed substantial spatial variability (figs. 10a and 10b). The downstream profiles of $\mathrm{Ca}, \mathrm{Cu}$, and $\mathrm{Fe}$ concentrations showed different patterns related to their respective sources and geochemical behavior. Calcium was derived from both mining and non-mining sources. The pattern of $\mathrm{Ca}$ after the addition from the Glengary adit reflects weathering from non-mining sources. The pattern of $\mathrm{Cu}$ represents the other metals, such as $\mathrm{Al}$, manganese $(\mathrm{Mn})$, and $\mathrm{Zn}$. The patterns of $\mathrm{Ca}$ and $\mathrm{Cu}$ were very similar with two exceptions. First, concentrations of $\mathrm{Cu}$ were relatively greater upstream from the Glengary adit, which may result from natural drainage of the porphyry deposit in the watershed. Second, the Ca concentration increased downstream from $1,750 \mathrm{~m}$. Inflows on the right bank (looking downstream) drain limestone outcrops. Iron also is derived from mine drainage but showed a different behavior. Like $\mathrm{Ca}$ and $\mathrm{Cu}$ concentrations, the $\mathrm{Fe}$ concentration increased downstream from the Glengary adit, but after the inflow of FCT-11, the Fe concentration dropped to a value lower than the $\mathrm{Ca}$ and $\mathrm{Cu}$ concentrations, indicating that it was removed by chemical reaction.

Both ferrous iron ( $\mathrm{Fe}(\mathrm{II}))$ and filtered $\mathrm{Fe}$ were measured in the synoptic water samples (table 5). Ferric iron ( $\mathrm{Fe}(\mathrm{III})$ ) was assumed to be equal to the difference between the filtered $\mathrm{Fe}$ and $\mathrm{Fe}$ (II) concentrations. Filtration with $0.45-\mu \mathrm{m}$ filters likely allowed colloidalsized Fe(III) particles to be analyzed as part of the filtered Fe concentration. Although dissolved Fe(III) has been measured in other streams using ultrafiltration 


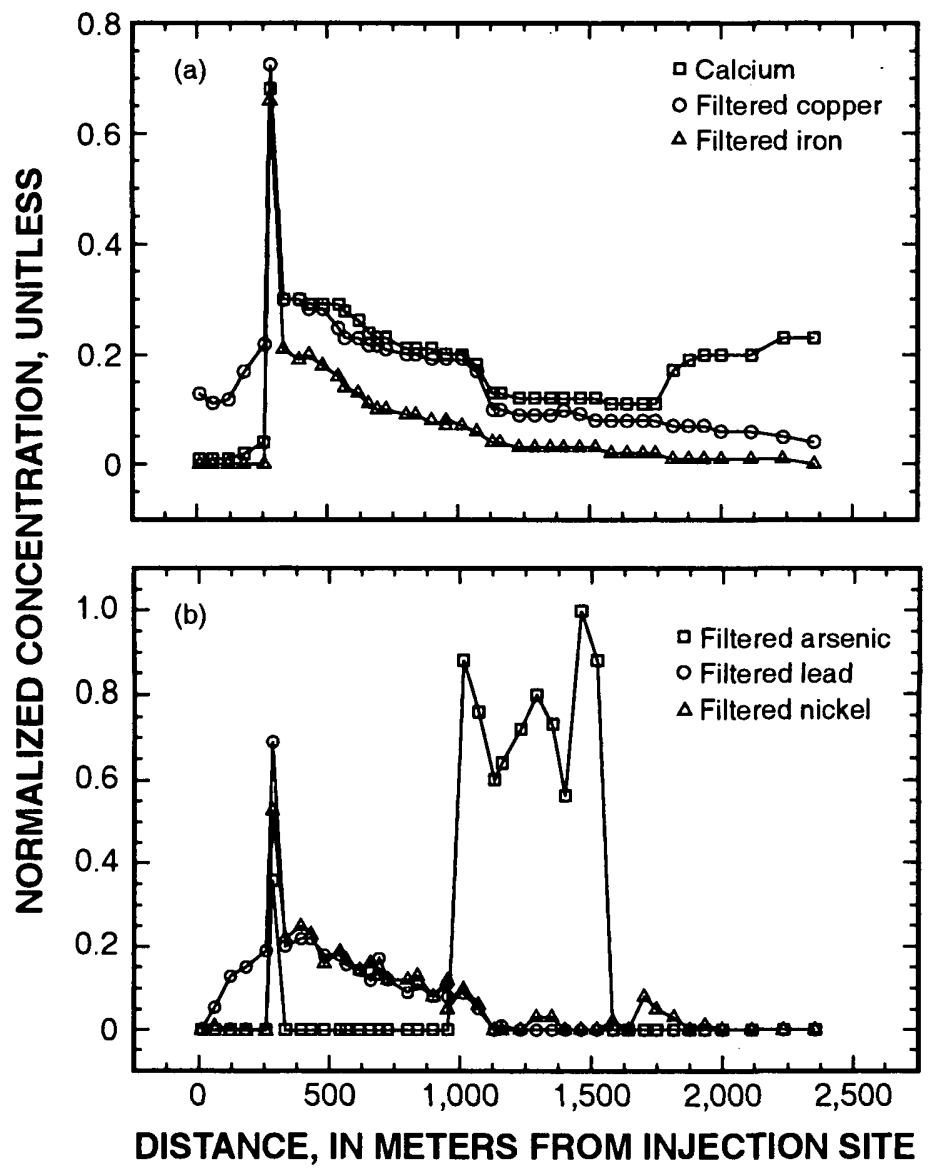

Figure 10. Variation of normalized concentrations of (a) calcium, filtered copper, and filtered iron; and (b) filtered arsenic, filtered lead, and filtered nickel, with distance from the injection site, Fisher Creek, Montana, August 19, 1997.

(Kimball and others, 1992; 1994), it is not possible to state it was present in Fisher Creek using 0.45- $\mu \mathrm{m}$ filtration. For these samples, $\mathrm{Fe}(\mathrm{II})$ may be a better measure of truly dissolved Fe concentrations.

Most of the Fe entered the stream as Fe(III) at the Glengary adit, and the decrease in concentration downstream resulted from the settling of aggregated colloidal $\mathrm{Fe}$ and photoreduction of $\mathrm{Fe}(\mathrm{III})$. The percentage of $\mathrm{Fe}(\mathrm{II})$ increased downstream from the inflow of the Glengary adit from 12 percent to a maximum of 91 percent at 2,235 m (fig. 11). Because samples were collected over several hours, the downstream pattern could have been affected by daily variations. If there had been an effect during the daylight hours, it would have been the opposite of this trend; higher Fe(II) percentages would have occurred upstream in the samples collected after 1200 (McKnight and others, 1988). The increase in the percentage of Fe(II) with transport downstream likely represents loss of $\mathrm{Fe}$ (III) by precipitation of Fe mineral phases.

\section{Minor Metals}

The metals that occur in trace concentrations indicate details about the sources and processes that affect the metals (fig. 10b). Filtered arsenic (As) concentrations were greater than detection immediately downstream from the Glengary adit and then occurred again downstream from most of the metal-rich inflows to the stream. Arsenic occurs as an anionic species in natural waters, which causes it to behave differently than a metal in water. Although the increased $\mathrm{pH}$ between $1,015 \mathrm{~m}$ and $1,522 \mathrm{~m}$ might have caused the increase in As concentration by desorption of As from Fe colloids, there was no evidence of colloidal As. Also, the abrupt decrease downstream would not be consistent. High concentrations of filtered lead $(\mathrm{Pb})$ 


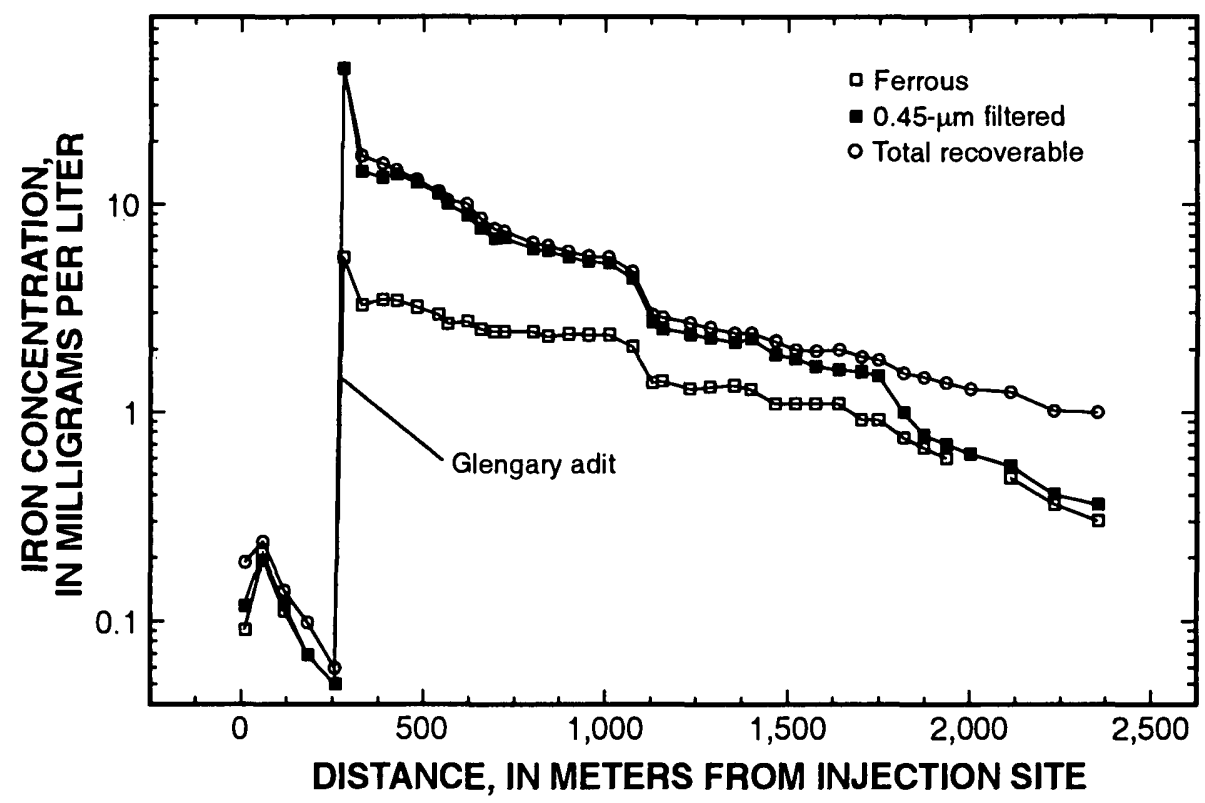

Figure 11. Variation of ferrous, filtered, and total-recoverable iron with distance from the injection site, Fisher Creek, Montana, August 19, 1997.

mostly resulted from the inflow of the Glengary adit, but similar to filtered $\mathrm{Cu}$, there was a relatively high concentration upstream from the adit that could be the result of natural acidic drainage. Concentrations of filtered nickel were clearly part of the mine drainage contribution from the Glengary adit, but there was also a small increase at $1,702 \mathrm{~m}$ that could indicate mine drainage in that part of the stream.

These patterns of metal concentrations could be the result of physical or chemical processes. Only by viewing the various processes in a hydrologic context can their effects be determined.

\section{QUANTIFICATION OF LOADING}

The sampled instream load contains information about the contribution of each stream segment and about the net effects of chemical and physical processes affecting metal transport (Broshears and others, 1995; Kimball and others, 1994). Interpretation of the sampled instream load is facilitated by comparison to the cumulative total load and the cumulative inflow load. The cumulative total load indicates the mass that enters the stream disregarding any loss from chemical or physical processes and is the sum of net gains for stream segments from equation 4.

\section{Loads of Major Ions}

\section{Calcium}

Although the highest Ca concentration occurred just downstream from the Glengary adit (fig. 10a), the load of $\mathrm{Ca}$ in the stream at that point was only a small part of the total load at the bottom of the study reach (fig. 12a). This points out the substantial difference between the load profile and the concentration profile. The sampled instream load for Ca closely follows the cumulative total load because there were no chemical processes that removed $\mathrm{Ca}$ in this setting. Most of the total load came from the inflows downstream from $1,750 \mathrm{~m}$ ( 62 percent), but the Glengary adit, FCT-2, and FCT- 11 contributed 20 percent of the load. About 65 percent of the $\mathrm{Ca}$ loading came from visible inflows to Fisher Creek, so that the cumulative inflow load mostly followed the cumulative total load (fig. 12a).

The load attributed to each stream segment is illustrated by the bar graph (fig. 12b). There are three different kinds of bars. The load that can be attributed to visible inflows (eq. 5) is indicated, and if the sampled instream load increased by more than the load from a visible inflow ( $\Delta M_{S}$ was greater than $\Delta M_{I}$, table 3$)$, then the difference is shown by the bar labeled subsurface inflow. Finally, if there is a net loss for a stream segment, that loss is indicated. One special condition 

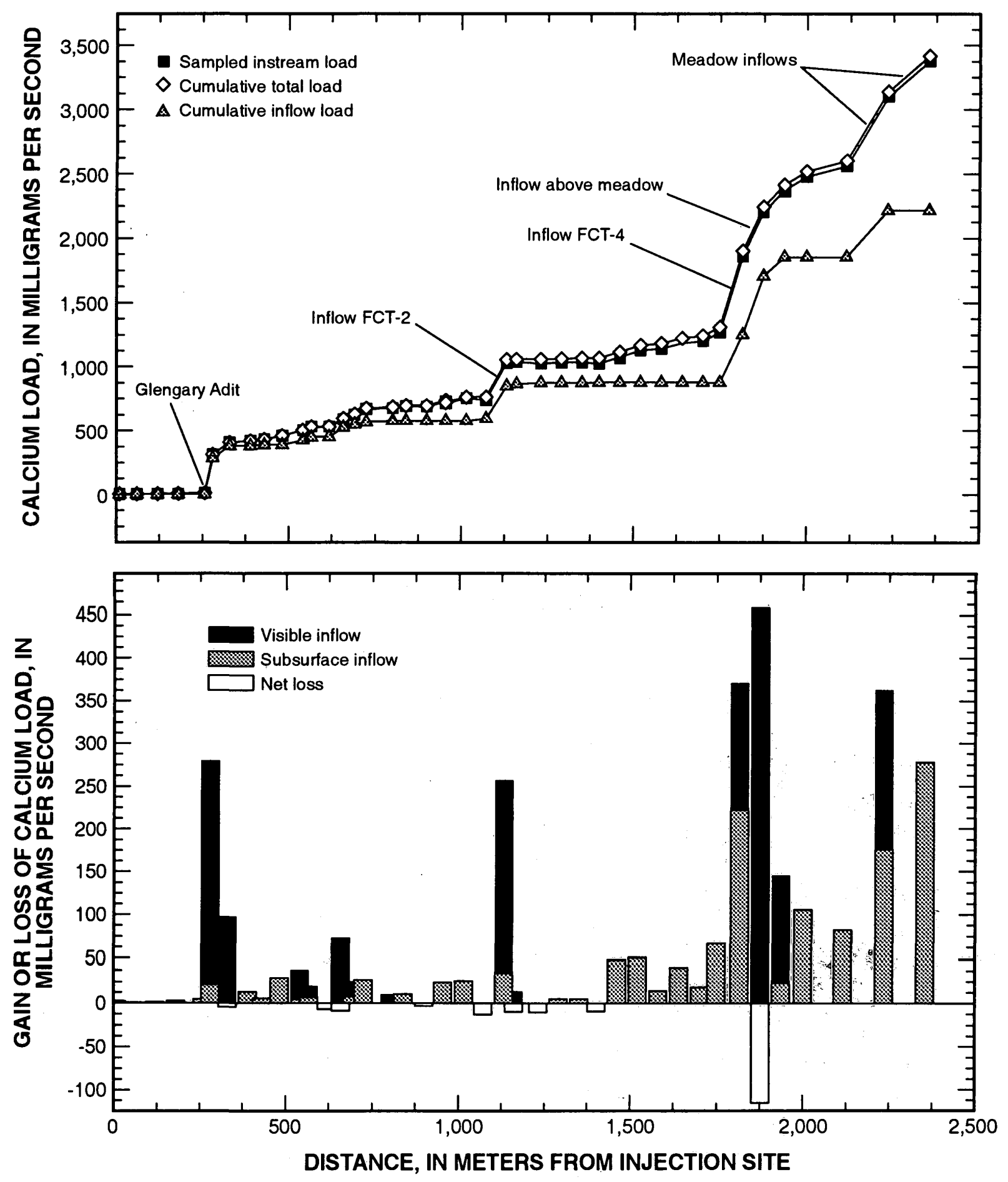

Figure 12. (a) Sampled instream load, cumulative total load, and cumulative inflow load of calcium, and (b) net gain or loss of calcium load, Fisher Creek, Montana, August 19, 1997. 
occurred in a few stream segments. If there was a net loss for a segment and there was also a visible inflow, then bars were shown for each. The total loss for the stream segment likely is greater than the amount shown for the net loss in this situation. The bars in figure $12 b$ and subsequent load figures present details for individual stream segments.

\section{Sulfate}

There are two important contrasts between the loads of $\mathrm{Ca}$ and $\mathrm{SO}_{4}$. First, there was a much larger difference between the cumulative total load and the cumulative inflow load; the cumulative inflow load only accounted for about 58 percent of the cumulative total load of $\mathrm{SO}_{4}$ (fig. 13a). Part of this difference was logistic because fewer of the small inflows were sampled farther from the principal sources of metal inflow. To account for mass loading in stream segments without sampled inflows, the change in discharge for the segment was multiplied by an estimate of inflow concentrations that were estimated from concentrations of nearby sampled inflows. This increased the estimate of cumulative inflow load by $3.48 \mathrm{mg} / \mathrm{s}$, making it 58 percent instead of 43 percent of the cumulative total load.

The 42-percent difference in the cumulative total and the cumulative inflow loads can indicate that subsurface water entering the stream had $\mathrm{SO}_{4}$ concentrations that were higher than the $\mathrm{SO}_{4}$ concentration in the sampled inflows. Second, there was a substantial difference between the cumulative total load and the sampled instream load of $\mathrm{SO}_{4}$. The most likely cause for this difference was chemical reactions that affected the $\mathrm{SO}_{4}$ load. Removal of $\mathrm{SO}_{4}$ could be through sorption to $\mathrm{Fe}$ hydroxide colloids at low $\mathrm{pH}$ or coprecipitation of $\mathrm{SO}_{4}$ as part of $\mathrm{Fe}$-oxyhydroxysulfate minerals (Bigham and others, 1990; Bigham and others, 1996; Brady and others, 1986). The greatest loss of $\mathrm{SO}_{4}$ load occurred downstream from $2,115 \mathrm{~m}$ (fig. 13b).

\section{Loads of Metals}

Patterns of metal loads from mine drainage were more comparable to $\mathrm{SO}_{4}$ than to $\mathrm{Ca}$ because of the substantial number of dispersed subsurface inflows and the reactive chemistry that affected their transport. The extent of chemical reaction was greatest for $\mathrm{Fe}$, but also significant for $\mathrm{Al}, \mathrm{Cu}, \mathrm{Mn}$, and $\mathrm{Zn}$.
Iron

Thermodynamically, Fe should readily precipitate within the $\mathrm{pH}$ range of Fisher Creek to form colloidal-sized, hydrous Fe oxide solids (Lindsay, 1979; Pankow, 1991). Through a sequence that includes precipitation to form nanometer-sized particles, aggregation to form micrometer-sized particles, settling of aggregated colloids, and entrapment by biofilm on cobbles, these colloidal Fe solids coat the streambed of Fisher Creek (Grundl and Delwiche, 1993). Many streams affected by mine drainage have a characteristic ochre-colored streambed from this process. This pattern of Fe loss has been documented in St. Kevin Gulch, Colorado, where a rate constant for the first-order removal of Fe was determined (Kimball and others, 1994). Accumulation of $\mathrm{Fe}$ precipitate on the streambed can affect the physical habitat of aquatic organisms and also can create a source of chronic toxicity because of the metals that readily sorb to the Fe colloids.

The mass-load profile of filtered Fe was very different from the profiles of $\mathrm{Ca}, \mathrm{SO}_{4}$, and the other filtered metals (fig. 14a). Because of the reactive behavior of $\mathrm{Fe}$, it is very difficult to account for the total inflow of $\mathrm{Fe}$. It is possible that $\mathrm{Fe}$ was removed fast enough to cause a net loss in almost every segment of the stream; there were few positive values of $\Delta M_{S}$ (fig. 14b). Thus, the actual amount of Fe lost from streamwater could have been greater than the difference between the cumulative total load and the sampled instream load might indicate (fig. 14).

Steps in the removal of $\mathrm{Fe}$ from the stream are illustrated by looking at the load profiles of $\mathrm{Fe}(\mathrm{II})$, filtered, and total-recoverable Fe (fig. 14). First, the Glengary adit and FCT-11 were two large point sources of Fe to the stream at about $300 \mathrm{~m}$. As this large input of $\mathrm{Fe}$ was transported downstream, $\mathrm{Fe}$ (III) precipitated in the water column as Fe colloids, aggregated, and settled from the stream or was entrapped by biofilm. This results in the continuous decrease in filtered and totalrecoverable Fe loads. The nearly constant difference between these two loads, continuing for about $1,000 \mathrm{~m}$ of the stream, indicates a constant process of precipitation, aggregation, and removal. With the $\mathrm{pH}$ change downstream from 1,750 $\mathrm{m}$ and an increase of Fe load, the formation of $\mathrm{Fe}$ colloids accelerated. More colloidal Fe was in the water column, as indicated by a greater difference between filtered $\mathrm{Fe}$ and total-recoverable $\mathrm{Fe}$ loads. The rate of settling, however, did not seem to change because there was little change in the decrease 

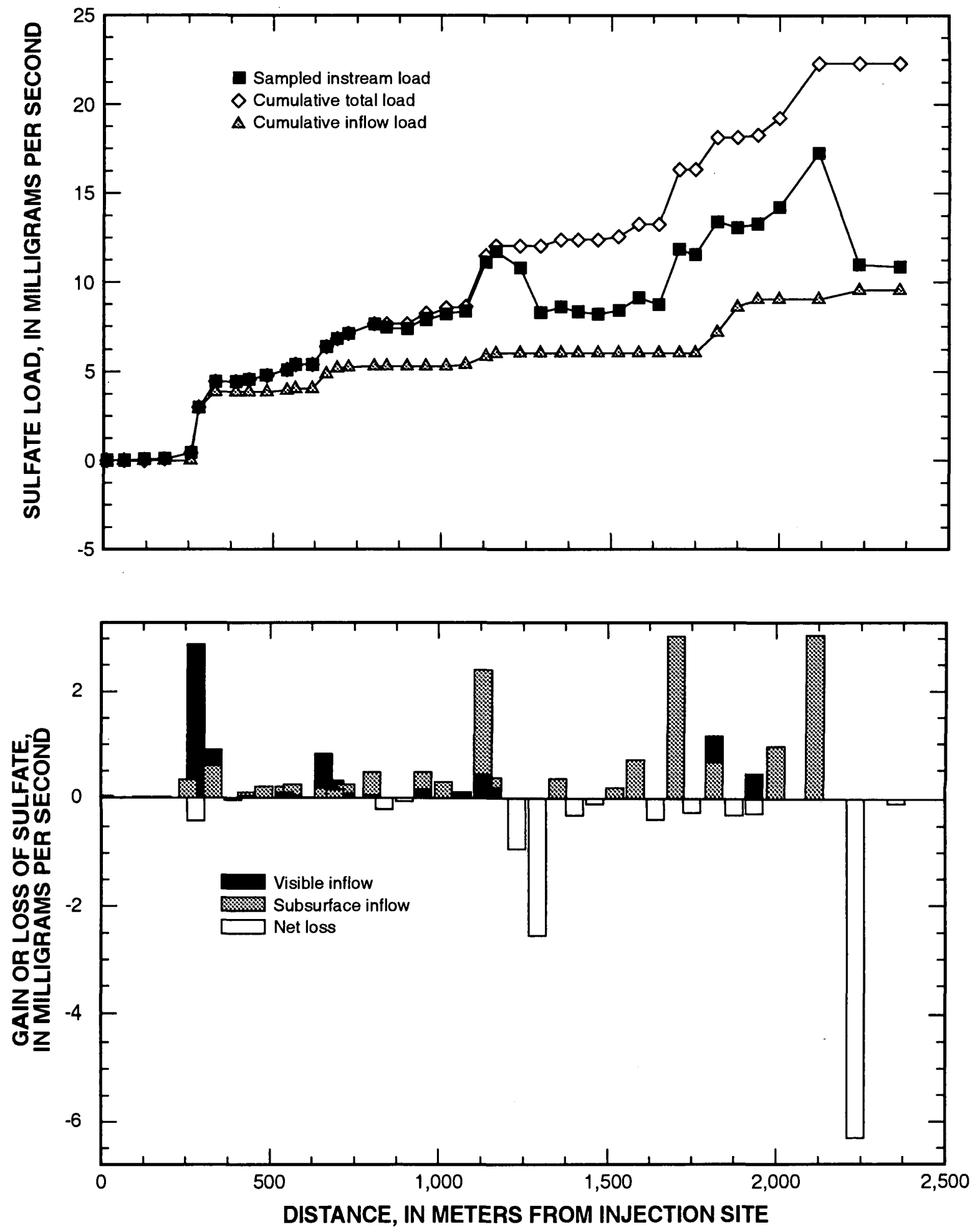

Figure 13. (a) Sampled instream load, cumulative total load, and cumulative inflow load of sulfate, and (b) net gain or loss of sulfate load, Fisher Creek, Montana, August 19, 1997. 

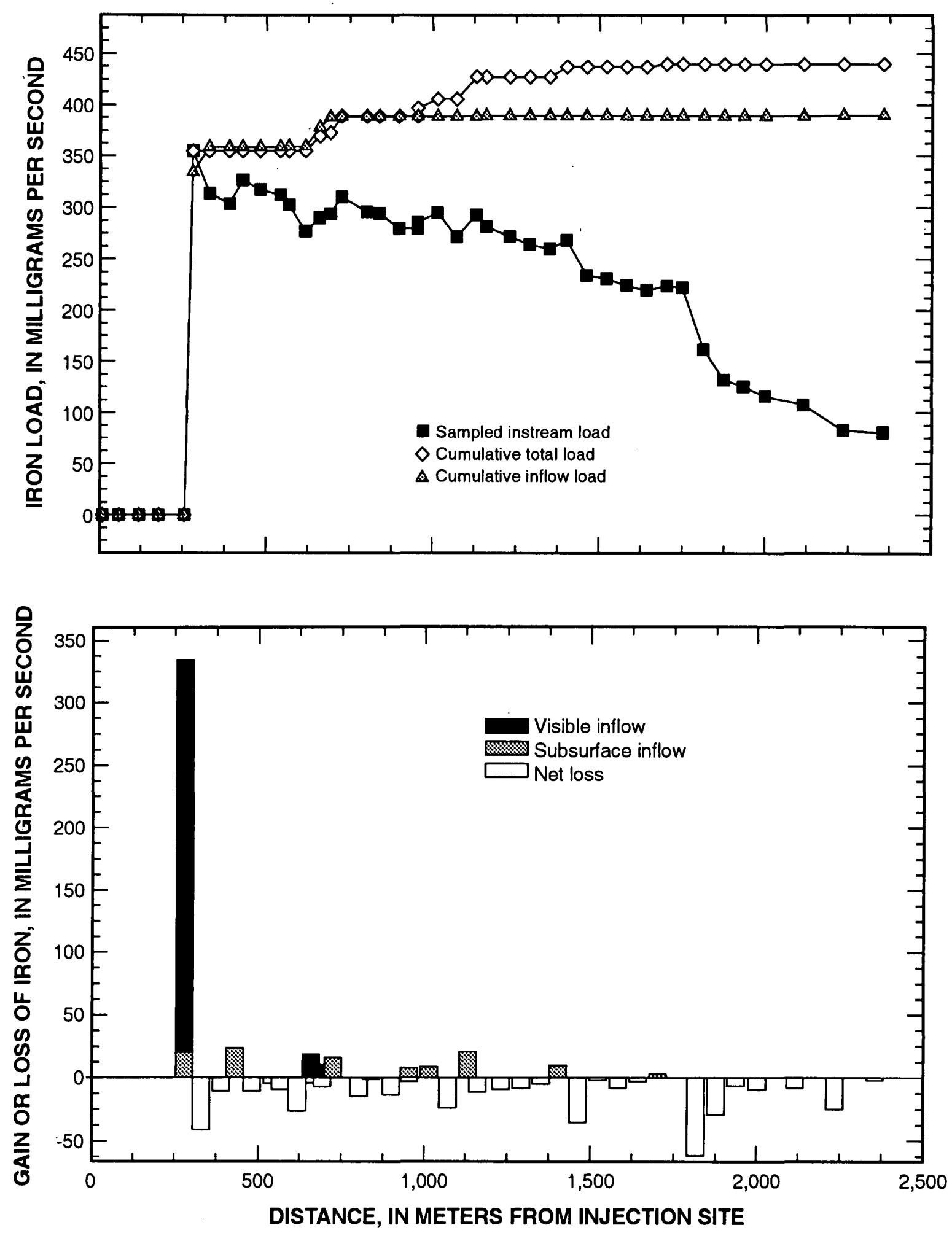

Figure 14. (a) Sampled instream load, cumulative total load, and cumulative inflow load of iron, and (b) net gain or loss of iron, Fisher Creek, Montana, August 19, 1997. 
of total-recoverable Fe load with distance. As the filtered Fe load reached the level of the Fe(II) load, the $\mathrm{Fe}$ (II) decreased along with the filtered Fe, possibly indicating that $\mathrm{Fe}$ (II) was converted to $\mathrm{Fe}$ (III) and then precipitated as Fe colloids.

Fe-rich colloids that settle to the streambed or are trapped by algae on streambed cobbles, are flushed by snowmelt runoff the following year. This was the likely cause of large increases in colloidal loads of metals in the Animas River, Colorado, during snowmelt runoff (Church and others, 1997).

\section{Aluminum, Copper, Manganese, and Zinc}

The most striking difference between the profile of Ca load and the profiles of metal loads is the relative importance of the different sources. Sources of $\mathrm{Ca}$ load occur all along the study reach, but a large part of the metal loads comes from the Glengary adit and other mine-related sources in the first $700 \mathrm{~m}$ of the study reach (figs. 15, 16, 17, and 18). About 60 percent of the $\mathrm{Al}, \mathrm{Cu}, \mathrm{Mn}$, and $\mathrm{Zn}$ loads can be accounted for by the concentrations in the samples of the visible inflows, and almost all of these loads entered Fisher Creek in the upper $700 \mathrm{~m}$. This means the cumulative inflow load is much closer to the cumulative total load for these metals than for $\mathrm{SO}_{4}$. The remaining 40 percent was from diffuse subsurface inflows. Considering this diffuse source, the reduction of metal loads in Fisher Creek might be limited unless there were a way to reduce loads from the diffuse sources as well as reducing loads from the Glengary adit and nearby mining wastes. For example, the load of $\mathrm{Cu}$ from the Glengary adit was 28 $\mathrm{mg} / \mathrm{s}$, which was 32 percent of the total load at the end of the study reach (fig. 15). A decrease of 32 percent of the load may not reduce $\mathrm{Cu}$ to concentrations that would be low enough for a healthy fish population. Also, eliminating inflow of the Glengary adit would increase the $\mathrm{pH}$ of Fisher Creek, and reduce the load of $\mathrm{Fe}$, changing the dynamics of $\mathrm{Cu}$ sorption to $\mathrm{Fe}$ colloids. With these chemical complexities, the exact amount of reduction in $\mathrm{Cu}$ for eliminating a particular source needs to be estimated by a reactive solute-transport simulation; it is not a simple mass-balance question.

Loads for filtered $\mathrm{Al}, \mathrm{Cu}, \mathrm{Mn}$, and $\mathrm{Zn}$ showed the same general pattern. The major loads from the Glengary adit and nearby mining wastes initially dominate the load profiles. Transport of that load was conservative for each metal to about $800 \mathrm{~m}$. From $802 \mathrm{~m}$ to $1,582 \mathrm{~m}$, the sampled instream load and the cumulative total loads diverged because of net losses in some stream segments as a result of chemical reactions. These decreases in load occurred downstream from neutral inflows that raised the instream $\mathrm{pH}$. The decreases could have resulted from sorption of the metals to the Fe colloids or from coprecipitation with the $\mathrm{Fe}$ colloids. Amacher and others (1994) have shown a marked increase in the $\mathrm{Cu}$ concentration in the streambed Fe precipitates in this same area of Fisher Creek. None of the total-recoverable metal concentrations increased in this reach (table 6), indicating that there must have been sorption directly to bed material. After the instream metal loads decreased, each metal load subsequently increased between $1,582 \mathrm{~m}$ and $1,750 \mathrm{~m}$. This area had no visible inflows; the increased load must represent metal-rich, subsurface inflow. The source of this metal-rich inflow was not apparent and should be investigated further

The loading of $\mathrm{Al}$ was different from the other metals downstream from the inflow at $2,116 \mathrm{~m}$ (fig. 16a). With the increase in $\mathrm{pH}, \mathrm{Al}$ precipitated, as indicated by the sharp decline in load. There was visible evidence of precipitation on the streambed cobbles along the right bank downstream from the inflow. The load of $\mathrm{Cu}$ also decreased in that reach, most likely as a result of sorption of $\mathrm{Cu}$ onto the $\mathrm{Fe}$ and $\mathrm{Al}$ precipitates rather than by precipitation of a solid phase. If $\mathrm{Cu}$ and other metals are stored on the streambed with Fe colloids, they could be flushed by the next snowmelt runoff.

Mass-load profiles of Mn (fig. 17) and $\mathrm{Zn}$ (fig. 18) were similar. For both, the Glengary adit was the principal source of the metal load. The largest losses occurred in the area from $1,402 \mathrm{~m}$ to $1,462 \mathrm{~m}$ and from $2,115 \mathrm{~m}$ to $2,235 \mathrm{~m}$, both in response to inflows that had high $\mathrm{pH}$. Between 1,750 $\mathrm{m}$ and 1,936 $\mathrm{m}$ the load of $\mathrm{Zn}$ increased due to subsurface inflows, but the Mn load did not increase. This could indicate a mineralogical difference between the source of metals in that area and the source of the Glengary adit.

Despite the differences in details among the mass-load profiles, the metal loads collectively indicate five areas where most of the metal loads entered the stream. The net gain or loss of metals in each stream segment is summarized in table 7 . For each metal, the five largest increases are shaded to point out the principal areas of loading. The first area was between $257 \mathrm{~m}$ and $330 \mathrm{~m}$, including the Glengary adit and the FCT- 11 tributary. The second area was between $618 \mathrm{~m}$ and 725 $\mathrm{m}$, where streams that drain waste-rock piles enter Fisher Creek. The third important area was between 

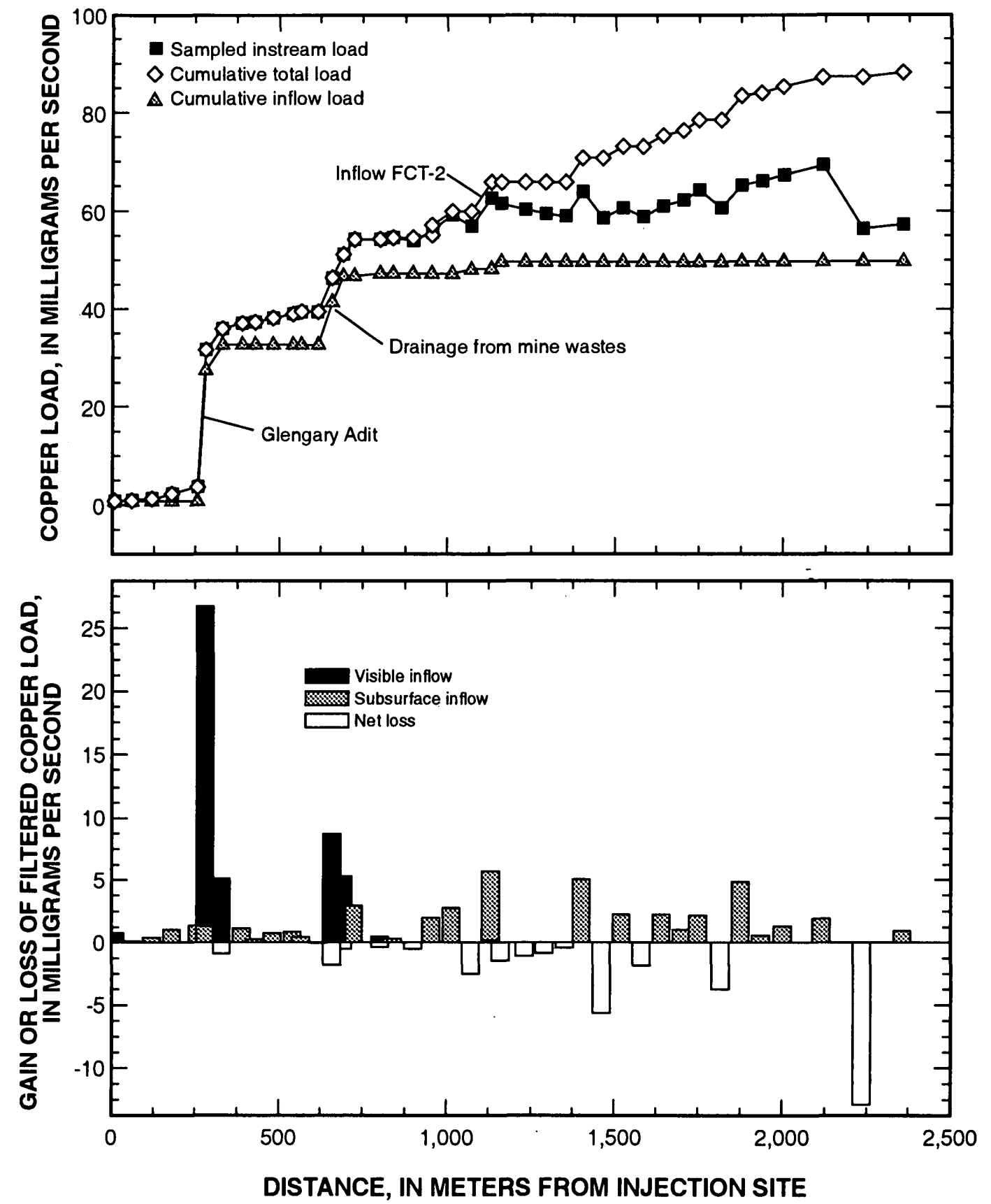

Figure 15. (a) Sampled instream load, cumulative total load, and cumulative inflow load of filtered copper, and (b) net gain or loss of filtered copper load, Fisher Creek, Montana, August 19, 1997. 

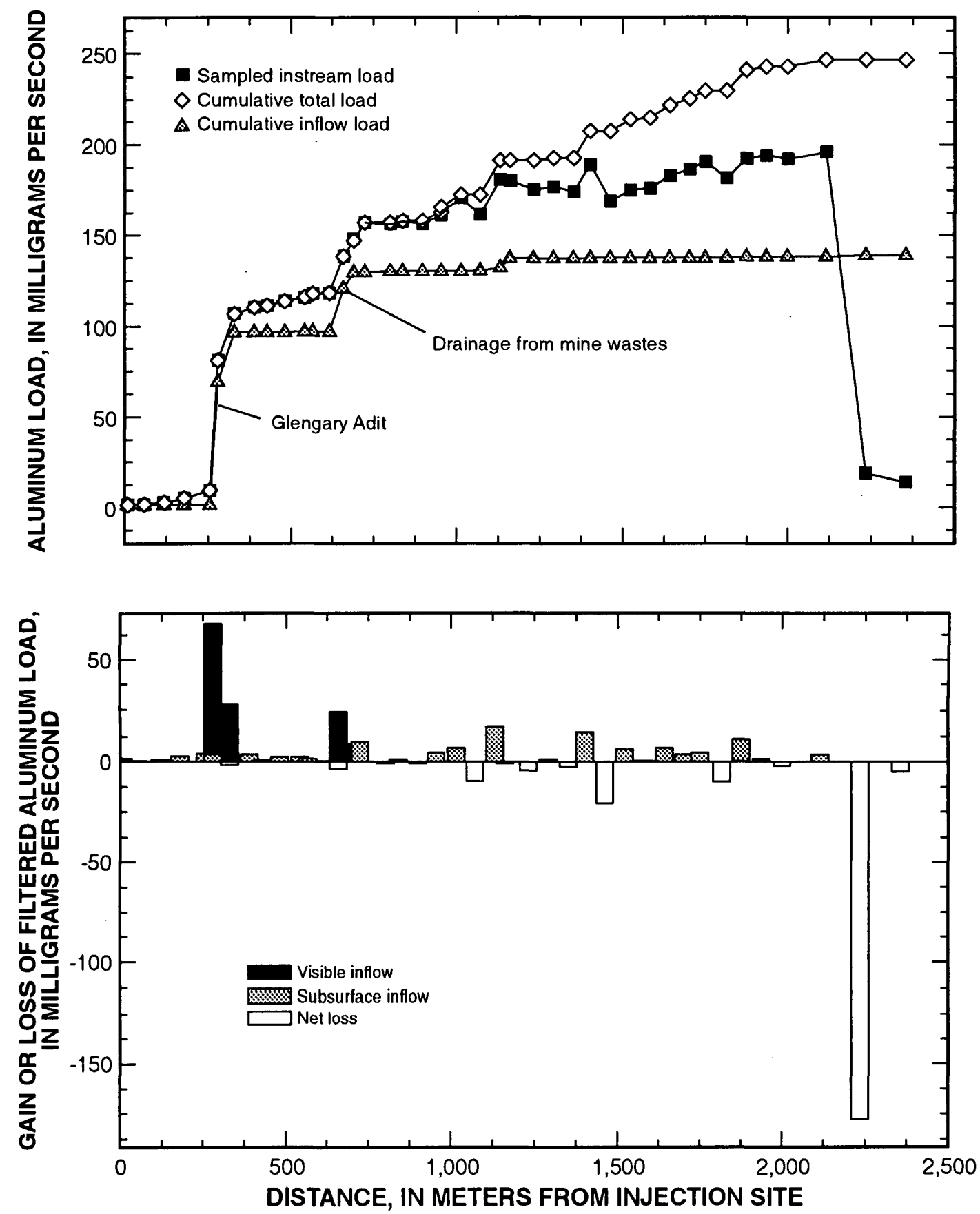

Figure 16. (a) Sampled instream load, cumulative total load, and cumulative inflow load of filtered aluminum, and (b) net gain or loss of filtered aluminum load, Fisher Creek, Montana, August 19, 1997. 

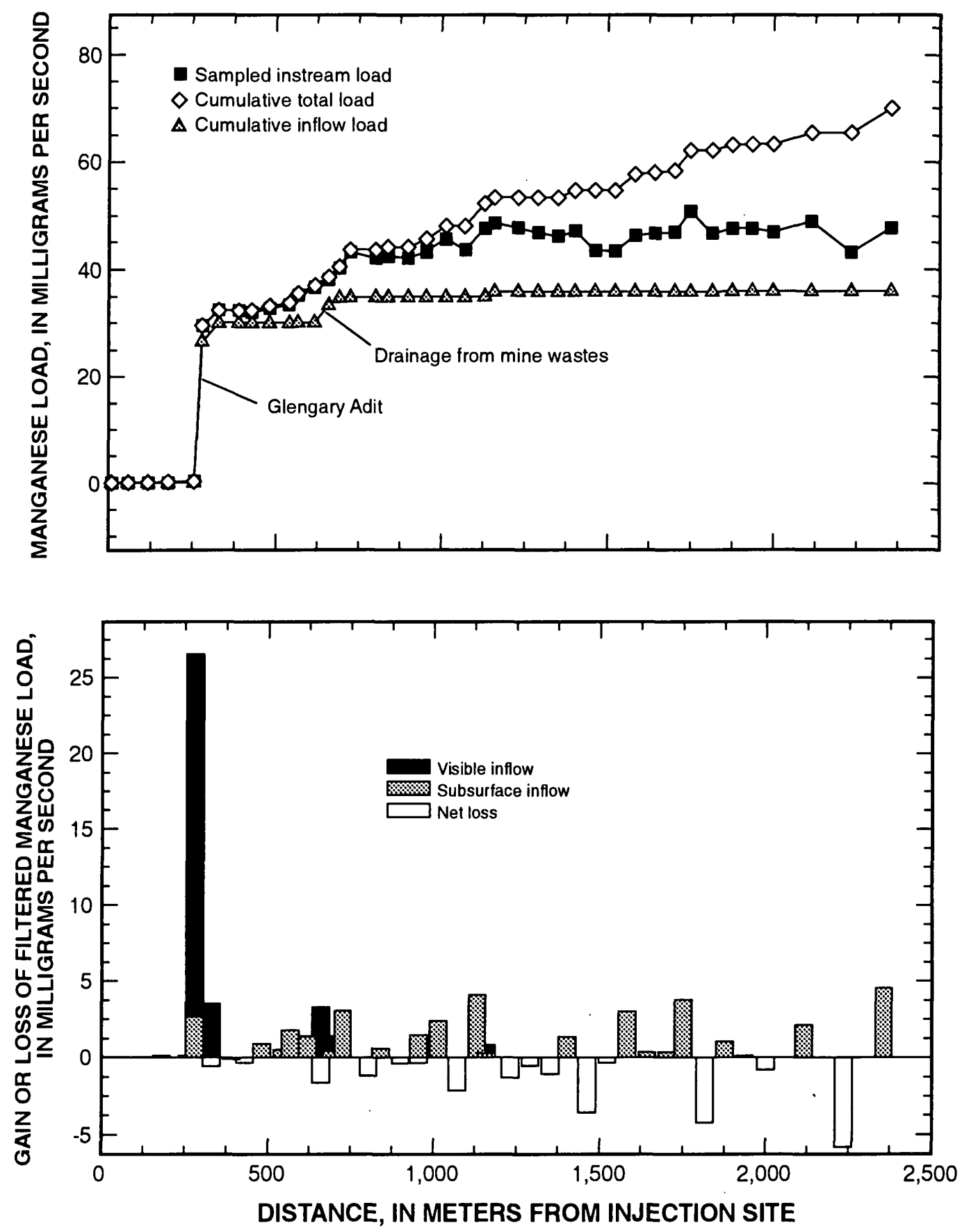

Figure 17. (a) Sampled instream load, cumulative total load, and cumulative inflow load of filtered manganese, and (b) net gain or loss of filtered manganese load, Fisher Creek, Montana, August 19, 1997. 

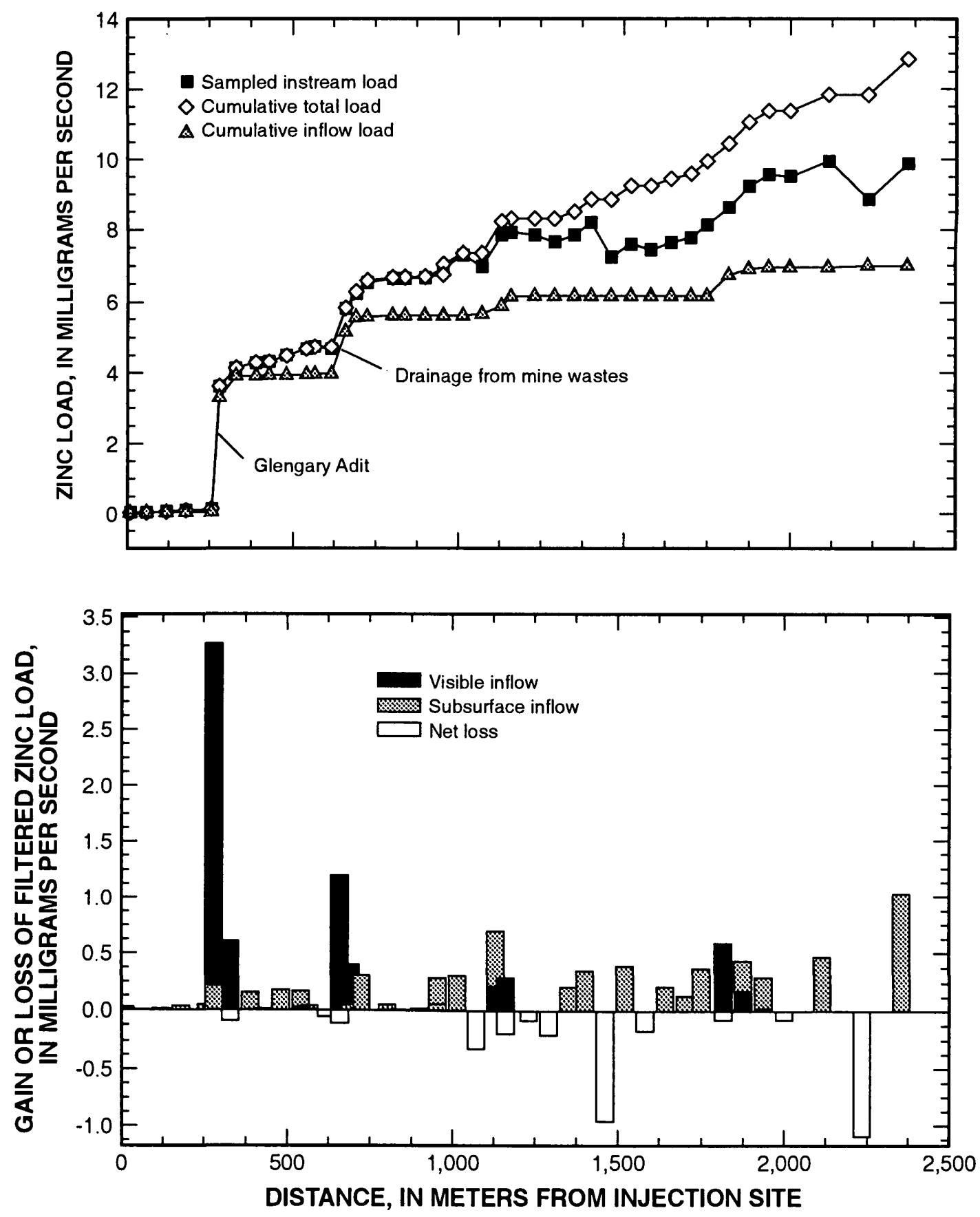

Figure 18. (a) Sampled instream load, cumulative total load, and cumulative inflow load of filtered zinc, and (b) net gain or loss of filtered zinc load, Fisher Creek, Montana, August 19, 1997. 
Table 7. Net gain or loss of selected metals and sulfate in stream segments of Fisher Creek, Montana, August 1997 [All values are in milligrams per second]

\begin{tabular}{|c|c|c|c|c|c|c|c|}
\hline $\begin{array}{l}\text { Distance } \\
\text { (m) }\end{array}$ & Calcium & Sulfate & Aluminum & Copper & Iron & Manganese & Zinc \\
\hline 10 & 2.80 & 0.04 & 1.50 & 0.79 & 0.13 & 0.05 & 0.03 \\
\hline 60 & 1.37 & .01 & .36 & .09 & .19 & .06 & .02 \\
\hline 120 & 1.24 & .02 & 1.01 & .35 & -.09 & .04 & .01 \\
\hline 180 & 2.54 & .02 & 2.59 & 1.04 & -.06 & .10 & .03 \\
\hline 257 & 4.37 & .33 & 4.11 & 1.39 & -.01 & .11 & .05 \\
\hline 280 & 301 & 2.50 & 71.5 & 28.1 & 355 & 29.2 & 3.48 \\
\hline 330 & 94.0 & 1.50 & 25.7 & 4.22 & -4.98 & 2.92 & .51 \\
\hline 390 & 12.8 & -.04 & 3.58 & 1.13 & -1.35 & -.10 & .15 \\
\hline 430 & 11.3 & .13 & 1.03 & .28 & 23.8 & -.34 & .02 \\
\hline 482 & 29.7 & .21 & 2.33 & .79 & -1.48 & .89 & .17 \\
\hline 542 & 42.9 & .31 & 2.46 & .85 & -4.66 & .52 & .19 \\
\hline 567 & 27.0 & .29 & 1.61 & .46 & -9.38 & 1.78 & .06 \\
\hline 618 & -6.58 & .00 & .50 & -.04 & -26.4 & 1.42 & -.05 \\
\hline 659 & 65.0 & 1.01 & 2.32 & 6.90 & 14.3 & 1.62 & 1.09 \\
\hline 692 & 33.1 & .45 & 8.78 & 4.74 & 3.34 & 1.86 & .45 \\
\hline 725 & 45.2 & .30 & 9.83 & 3.01 & 16.41 & 3.11 & .32 \\
\hline 802 & 9.64 & .52 & -.89 & .14 & -14.6 & -1.20 & .09 \\
\hline 840 & 11.1 & -.19 & 1.22 & .29 & -1.43 & .60 & .01 \\
\hline 900 & -2.65 & -.05 & -.68 & -.53 & -13.3 & -.39 & .02 \\
\hline 955 & 24.2 & .47 & 4.53 & 1.98 & 7.56 & 1.47 & .28 \\
\hline 955 & 16.2 & .14 & 2.70 & .54 & -2.81 & -.37 & .05 \\
\hline 1,015 & 26.0 & .29 & 6.88 & 2.78 & 8.96 & 2.40 & .30 \\
\hline 1,072 & -12.6 & .10 & -9.47 & -2.50 & -23.4 & -2.13 & -.33 \\
\hline 1,132 & 293 & 2.83 & 19.0 & 5.92 & 21.7 & 4.19 & .89 \\
\hline 1,161 & 3.88 & .55 & -.55 & -1.44 & -11.2 & 1.07 & .08 \\
\hline 1,232 & -1.06 & -.92 & -4.38 & -1.06 & -9.19 & -1.30 & -.08 \\
\hline 1,292 & 4.95 & -2.55 & 1.31 & -.85 & -8.32 & -.53 & -.21 \\
\hline 1,352 & 4.76 & .34 & -2.48 & -.43 & -4.92 & -1.06 & .20 \\
\hline 1,402 & -9.10 & -.29 & 15.0 & 5.04 & 9.94 & 1.33 & .35 \\
\hline 1,462 & 48.8 & -.10 & -2.52 & -5.59 & -35.5 & -3.60 & -.96 \\
\hline 1,522 & 51.2 & .18 & 6.36 & 2.26 & -2.21 & -.32 & .38 \\
\hline 1,582 & 14.6 & .71 & .89 & -1.87 & -8.33 & 3.02 & -.18 \\
\hline 1,642 & 41.4 & -.37 & 6.92 & 2.26 & -2.69 & .35 & .21 \\
\hline 1,702 & 18.7 & 3.05 & 3.55 & 1.04 & 2.86 & .34 & .13 \\
\hline 1,750 & 66.8 & -.24 & 4.48 & 2.19 & -.68 & 3.78 & .36 \\
\hline 1,816 & 592.8 & 1.80 & -9.81 & -3.72 & -61.3 & -4.24 & .50 \\
\hline 1,876 & 343.2 & -.29 & 11.6 & 4.92 & -29.4 & 1.10 & .61 \\
\hline 1,936 & 168.7 & .16 & 1.60 & .58 & -6.48 & .11 & .32 \\
\hline 2,000 & 105.7 & .95 & -2.10 & 1.32 & -9.45 & -.83 & -.07 \\
\hline 2,115 & 82.6 & 3.06 & 3.60 & 1.94 & -8.49 & 2.11 & .46 \\
\hline 2,235 & 539 & -6.30 & -177 & -12.9 & -24.9 & -5.82 & -1.09 \\
\hline 2,355 & 278 & -.09 & -4.88 & .97 & -2.12 & 4.56 & 1.02 \\
\hline
\end{tabular}


$1,072 \mathrm{~m}$ and $1,132 \mathrm{~m}$, which receives the discharge from the largest visible inflow, FCT-2. A fourth area with substantial inflow was between $1,582 \mathrm{~m}$ and 1,750 $\mathrm{m}$, where increased load was mostly from subsurface inflow and not visible inflows. Finally, the area from $1,876 \mathrm{~m}$ to $1,936 \mathrm{~m}$ had a considerable increase of load for $\mathrm{Ca}, \mathrm{Al}$, and $\mathrm{Cu}$. This area likely drains carbonate outcrops on the right side of the canyon. The sources of $\mathrm{Al}$ and $\mathrm{Cu}$ are not clear, however, because drainage from the Gold Dust Mine does not appear to enter the inflow in this area.

\section{SUMMARY}

Acid mine drainage from past mining affects the water quality of Fisher Creek, Montana. To effectively plan for remediation requires detailed knowledge of the sources of the mine drainage, how the drainage from the sources enters the stream, and what natural attenuation may remove the metals once they are in the stream. The U.S. Geological Survey, in cooperation with the U.S. Environmental Protection Agency, conducted a tracer injection and synoptic sampling study to provide the information.

A chloride tracer injection allowed the calculation of discharge for synoptic samples along a 2,355-m reach of Fisher Creek. The study reach began upstream from the Glengary adit and ended in a downstream wetland, just upstream from site FC-5. The load profiles were calculated using discharge, calculated from the dilution of the tracer, and concentration data from detailed synoptic sampling. Loads of aluminum, copper, iron, manganese, and zinc greatly increased from the inflow of the Glengary adit. Downstream from the adit, metal transport was without substantial chemical reaction until the inflow of a tributary with higher $\mathrm{pH}$ (FCT-2), which caused instream $\mathrm{pH}$ to rise. Chemical reaction also decreased the loads of copper and aluminum in the wetland area, near the end of the study reach. At the higher $\mathrm{pH}$, aluminum changed from the filtered phase to colloidal solids and started settling from the stream. Chemical reactions substantially affected the load profile of iron along the entire study reach. The copper and zinc load profiles indicated the significance of ground-water inflows near the bottom of the study reach.

Calculating the cumulative total load and the cumulative inflow load helps indicate the extent of metal removal and the likely sources of ground-water inflow. Removal of metal loads from the stream has two important consequences. First, the metals are stored in iron colloids each summer and then are flushed by snowmelt runoff, likely causing a large increase of colloidal metal load for many kilometers downstream. Second, accounting for the total load facilitates the illustration of individual sources of metal loads.

The similarity of load profiles for the metals points out the impacts of mine drainage on Fisher Creek. A large part of the metal loads comes from the inflow of the Glengary adit, but substantial loads of each metal also occurred at other locations. Some loads came from diffuse subsurface inflow. Eliminating only a single source, without considering all principal sources, may not reduce instream concentrations to levels that do not adversely affect aquatic life.

\section{REFERENCES CITED}

Amacher, M.C., Brown, R.W., Sidle, R.C., and KotubyAmacher, J., 1991, Iron reactions in a headwater stream affected by acid mine drainage [abs.]: Eos, v. 44, p. 177.

1995, Effect of mine waste on element speciation in headwater streams, in Allen, H.E., Huang, C.P., Bailey, G.W., and Bowers, A.R., eds., Metal Speciation and Contamination of Soil, Boca Raton, Flor.: Chelsea, Mich., Lewis Publishers, p. 275309.

Amacher, M.C., Kotuby-Amacher, J., and Brown, R.W., 1994, Reactions, transport, and remediation of copper in acidic minespoils and sediments [abs.]: American Chemical Society program with abstracts, p. 1348-1349.

Bencala, K.E., Kimball, B.A., and McKnight, D.M., 1990 , Interaction of the substream zone with instream transport following a sharp change in solute concentration [abs.]: Eos, v. 71, p. 1317.

Bencala, K.E., and McKnight, D.M., 1987, Identifying in-stream variability: Sampling iron in an acidic stream, in Averett, R.C., and McKnight, D.M., eds., Chemical Quality of Water and the Hydrologic Cycle: Chelsea, Mich., Lewis Publishers, p. 255-269.

Bencala, K.E., McKnight, D.M., and Zellweger, G.W., 1990, Characterization of transport in an acidic and metal-rich mountain stream based on a lithium tracer injection and simulations of transient storage: Water Resources Research, v. 26, no. 5, p. 989-1000.

Bigham, J.M., Schwertmann, U., Carlson, L., and Murad, E., 1990, A poorly crystallized oxyhydrox- 
ysulfate of iron formed by bacterial oxidation of $\mathrm{Fe}(\mathrm{II})$ in acid mine waters: Geochimica et Cosmochimica Acta, v. 54, p. 2743-2758.

Bigham, J.M., Schwertmann, U., Traina, S.J., Winland, R.L., and Wolf, M., 1996, Schwertmannite and the chemical modeling of iron in acid sulfate waters: Geochimica et Cosmochimica Acta, v. 60, p. 21112121.

Brady, K.S., Bigham, J.M., Jaynes, W.F., and Logan, T.J., 1986, Influence of sulfate on Fe-oxide formation: Comparisons with a stream receiving acid mine drainage: Clays and Clay Minerals, v. 34, p. 266-274.

Brinton, T.I., Antweiler, R.C., and Taylor, H.E., 1996, Method for the determination of dissolved chloride, nitrate, and sulfate in natural water using ion chromatography: U.S. Geological Survey OpenFile Report 95-426A, 16 p.

Broshears, R.E., Bencala, K.E., Kimball, B.A., and McKnight, D.M., 1993, Tracer-dilution experiments and solute-transport simulations for a mountain stream, Saint Kevin Gulch, Montana: U.S. Geological Survey Water-Resources Investigations Report 92-4081, Denver, Colorado, 18 p.

Broshears, R.E., Runkel, R.L., and Kimball, B.A., 1995, Interpreting spatial profiles of concentration in acid mine drainage streams, in Hotchkiss, W.R., Downey, J.S., Gutentag, E.D., and Moore, J.E., eds., Water Resources at Risk, Summary of Application of Tracer Injection and Reactive Solute Transport Modeling to Characterize Mine Sites: American Institute of Hydrology, Minneapolis, Minn., p. LL-10-21.

Broshears, R.E., Runkel, R.L., Kimball, B.A., Bencala, K.E., and McKnight, D.M., 1996, Reactive solute transport in an acidic stream: experimental $\mathrm{pH}$ increase and simulation of controls on $\mathrm{pH}$, aluminum, and iron: Environmental Science \& Technology, v. 30, no. 10 , p. 3016-3024.

Church, S.E., Kimball, B.A., Fey, D.L., Ferderer, D.A., Yager, T.J., and Vaughn, R.B., 1997, Source, transport, and partitioning of metals between water, colloids, and bed sediments of the Animas River, Colorado: U.S. Geological Survey Open-File Report 97-151, $135 \mathrm{p}$.
Grundl, T., and Delwiche, J., 1993, Kinetics of ferric oxyhydroxide precipitation: Journal of Contaminant Hydrology, v. 14, p. 71-97.

Kimball, B.A., 1997, Use of tracer injections and synoptic sampling to measure metal loading from acid mine drainage: U.S. Geological Survey Fact Sheet FS-245-96, 4 p.

Kimball, B.A., Broshears, R.E., Bencala, K.E., McKnight, D.M., 1994, Coupling of hydrologic transport and chemical reactions in a stream affected by acid mine drainage: Environmental Science \& Technology, v. 28, p. 2065-2073.

Kimball, B.A., Callender, E., and Axtmann, E.V., 1995, Effects of colloids on metal transport in a river receiving acid mine drainage, upper Arkansas River, Colorado, U.S.A.: Applied Geochemistry, v. 10 , p. 285-306.

Kimball, B.A., McKnight, D.M., Wetherbee, G.A., and Harnish, R.A., 1992, Mechanisms of iron photoreduction in a metal-rich, acidic stream (St. Kevin Gulch, Colorado, U.S.A.): Chemical Geology, v. 96, p. 227-239.

Kimball, B.A., Runkel, R.L., and Gerner, L.J.,1999, Quantification of metal loading in French Gulch, Colorado, using a tracer-injection study, July 1996: U.S. Geological Survey Water-Resources Investigations Report 98-4078, 38 p.

Lindsay, W.L., 1979, Chemical equilibria in soils: New York, Wiley-Interscience, $449 \mathrm{p}$.

McKnight, D.M., Kimball, B.A., and Bencala, K.E., 1988, Iron photoreduction and oxidation in an acidic mountain stream: Science, v. 240 , p. $637-$ 640.

Pankow, J.F., 1991, Aquatic chemistry concepts: Chelsea, Mich., Lewis Publishers, 683 p.

Stream Solute Workshop, 1990, Concepts and methods for assessing solute dynamics in stream ecosystems: Journal of the North American Benthological Society, v. 9, p. 95-119.

Zellweger, G.W., Bencala, K.E., McKnight, D.M., Hirsch, R.M., and Kimball, B.A., 1988, Practical aspects of tracer experiments in acidic, metal enriched streams, in Mallard, G.E., ed., U.S. Geological Survey Toxic Substances Hydrology Program-Surface-Water Contamination, U.S. Geological Survey Open-File Report 87-764, p. 125-130. 
APPENDIX

\section{Ion-Chromatograph Analytical and Quality Assurance Procedures}

Chloride and sulfate were analyzed by the U.S. Geological Survey (USGS) Utah District laboratory using a Dionex 2002I ion chromatograph (IC) with an AS4A column, an AG4A guard, and a conductivity detector. All samples were filtered in the field through $0.45-\mu \mathrm{m}$ filters before analysis on the IC.

A typical analytical run included 64 samples. Of those 64 , only 39 (about 61 percent) were actual environmental samples. The remaining 25 samples ( 39 percent) included calibration standards, laboratorycertified standards and standard reference samples, site-specific standard reference samples, and blanks. Occasionally, analytical runs included fewer than 64 samples. In these cases, the percentage of environmental samples decreased relative to the percentage of other samples.

Six calibration standards were placed at the beginning of every run. External laboratory-certified standards were analyzed every fifth sample, a total of 11 in a run of 64 . A USGS laboratory standard reference sample was analyzed at the beginning and end of every run. Standards were collected from Fisher Creek at several times during the tracer injection so that sitespecific standard reference samples represented both background and plateau, or at least elevated $\mathrm{Cl}$ conditions. Appropriate site-specific standard reference samples were analyzed every tenth sample, a total of 5 in a run of 64 . One laboratory blank consisting of reagentgrade deionized water was analyzed at the end of every run.

Analytical procedures followed by the Utah District laboratory are outlined by Brinton and others
(1996). Three different volume sample loops were used in the determination of $\mathrm{Cl}$ and $\mathrm{SO}_{4}$ concentration with three different sets of calibration standards (table 8).

Background $\mathrm{Cl}$ concentrations and lower-level $\mathrm{SO}_{4}$ concentrations were determined using the $250-\mu \mathrm{L}$ sample loop. Most samples were analyzed on the $50-\mu \mathrm{L}$ loop, which provided the best middle-range results. The $10-\mu \mathrm{L}$ loop was used when $\mathrm{Cl}$ or $\mathrm{SO}_{4}$ concentrations exceeded upper limits of calibration for the $50-\mu \mathrm{L}$ sample loop or when they exceeded the upper limits of calibration for the $10-\mu \mathrm{L}$ sample loop and sample dilutions were required.

Laboratory-certified standards and USGS laboratory standard reference samples were analyzed so that short- and long-term accuracy and precision could be evaluated. Accuracy is defined as a measure of agreement between the measured concentration of an analyte and the actual concentration. The percentage error for $\mathrm{Cl}$ between the measured medians and the certified or most probable values was within 5 percent for five out of the six standard reference samples analyzed. The percentage error for $\mathrm{SO}_{4}$ between the measured medians and the certified or most probable values was within 5 percent for four out of the six standard reference samples. Those with a difference greater than 5 percent were within 10 percent (table 9).

The overall relation between measured median concentrations and certified or most probable values for $\mathrm{Cl}$ and $\mathrm{SO}_{4}$ in laboratory standard reference samples SR15, SR16, SR17, M102, and M140 have been plotted in figures 19 and 20. Standard reference samples M102 and M140 depart from the most probable values, while the median concentrations of others indicate reasonable accuracy. It should be remembered that the median concentrations do not reflect the actual scatter of results (fig. 21).

Table 8. Sample-loop volumes and minimum and maximum chloride and sulfate concentrations of each corresponding set of calibration standards for water samples from Fisher Creek, Montana, August 1997

$\left[\mu \mathrm{L}\right.$, microliters; mg/L, milligrams per liter; Min., minimum; $\mathrm{Cl}$, chloride; Max., maximum; $\mathrm{SO}_{4}$, sulfate]

\begin{tabular}{|c|c|c|c|c|}
\hline $\begin{array}{l}\text { Volume of sample loop } \\
\qquad(\mu \mathrm{L})\end{array}$ & Min. $\mathrm{Cl}(\mathrm{mg} / \mathrm{L})$ & Max. Cl (mg/L) & Min. $\mathrm{SO}_{4}(\mathrm{mg} / \mathrm{L})$ & $\operatorname{Max} . \mathrm{SO}_{4}(\mathrm{mg} / \mathrm{L})$ \\
\hline 250 & 0.00 & 1.00 & 0.00 & 25.0 \\
\hline 50 & .00 & 6.00 & .00 & 150 \\
\hline 10 & .00 & 60.1 & .00 & 300 \\
\hline
\end{tabular}




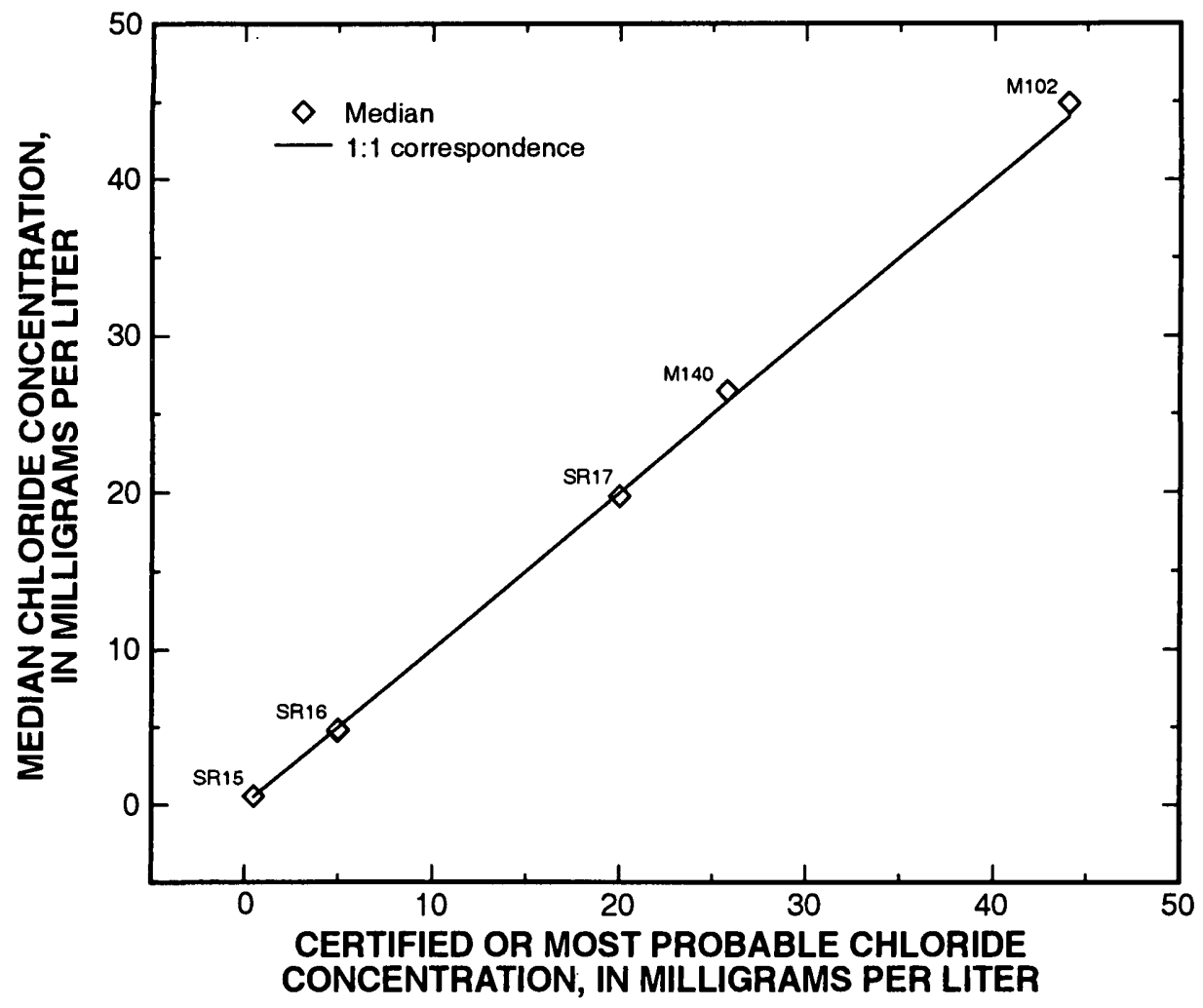

Figure 19. Relation of measured chloride concentration with certified or most probable concentration.

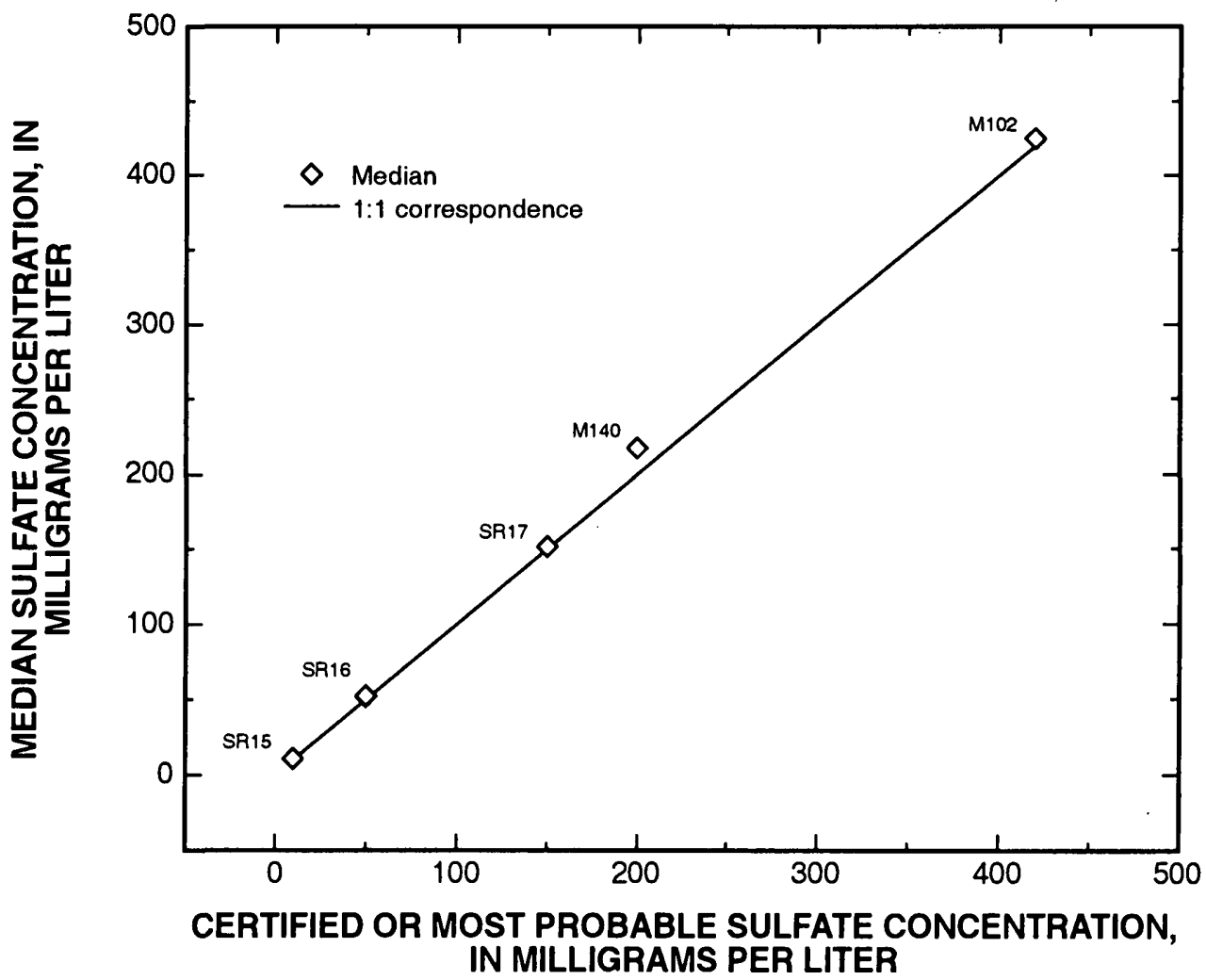

Figure 20. Relation of measured sulfate concentration with certified or most probable concentration. 
Table 9. Analysis of chloride and sulfate accuracy and precision from certified standards and standard reference samples from Fisher Creek, Montana, August 1997

[N, number of analyses; LCV, laboratory certified value; MPV, most probable value; \%Error, percent error; $t(n-1,0.99)$, student-t value for 99 percent probability; $\mathrm{P}_{c}$, precision; \%Precision, percent precision]

\begin{tabular}{|c|c|c|c|c|c|c|c|c|c|c|c|c|}
\hline $\begin{array}{c}\text { Sample } \\
\text { name }\end{array}$ & Source & Loop & $\mathrm{N}$ Analyte & $\begin{array}{l}\text { LCV or } \\
\text { MPV }\end{array}$ & Median & $\%$ Error & $\begin{array}{l}\text { Standard } \\
\text { deviation }\end{array}$ & Minimum & Maximum & $t(n-1,0.99)$ & $\mathbf{P}_{\mathrm{c}}$ & \% Precision \\
\hline \multirow[t]{2}{*}{ SR15 } & Lab & 250 & $27 \mathrm{Cl}$ & 0.50 & 0.53 & 5.7 & 0.02 & 0.50 & 0.56 & 2.479 & 0.0496 & 9.92 \\
\hline & Lab & 250 & $28 S O 4$ & 10.00 & 10.86 & 8.6 & .85 & 9.58 & 12.43 & 2.473 & 2. 1021 & 21.02 \\
\hline \multirow[t]{2}{*}{ SR16 } & Lab & 10 & $13 \mathrm{Cl}$ & 5.00 & 4.78 & 4.4 & .10 & 4.63 & 4.94 & 2.681 & .2681 & 5.36 \\
\hline & Lab & 10 & $13 S O 4$ & 50.00 & 52.38 & 4.8 & 6.17 & 49.13 & 66.52 & 2.681 & 16.5418 & 33.08 \\
\hline \multirow[t]{2}{*}{ SR16 } & Lab & 50 & $74 \mathrm{Cl}$ & 5.00 & 4.88 & 2.4 & .16 & 4.56 & 5.23 & 2.383 & .3813 & 7.63 \\
\hline & Lab & 50 & $74 S_{0} 4$ & 50.00 & 52.28 & 4.6 & 6.90 & 39.51 & 66.73 & 2.383 & 16.4427 & 32.89 \\
\hline \multirow[t]{2}{*}{ SR17 } & Lab & 10 & $72 \mathrm{Cl}$ & 20.00 & 19.78 & 1.1 & .45 & 19.01 & 20.96 & 2.384 & 1.0728 & 5.36 \\
\hline & Lab & 10 & $72 S O 4$ & 200.00 & 217.32 & 8.7 & 12.32 & 197.06 & 248.65 & 2.384 & 29.3709 & 14.69 \\
\hline \multirow[t]{2}{*}{ M102 } & USGS & 50 & $18 \mathrm{Cl}$ & 44.00 & 44.89 & 2.0 & 2.42 & 41.62 & 49.40 & 2.567 & 6.2121 & 14.12 \\
\hline & USGS & 50 & $18 \mathrm{SO} 4$ & 420.00 & 425.08 & 1.2 & 19.93 & 394.68 & 461.14 & 2.567 & 51.1603 & 12.18 \\
\hline \multirow[t]{2}{*}{ M140 } & USGS & 10 & $16 \mathrm{Cl}$ & 25.80 & 26.46 & 2.6 & .50 & 25.57 & 27.29 & 2.602 & 1.3010 & 5.04 \\
\hline & USGS & 10 & $16 \mathrm{SO} 4$ & 150.00 & 151.33 & .9 & 2.81 & 146.56 & 157.00 & 2.602 & 7.3116 & 4.87 \\
\hline \multirow[t]{2}{*}{ SR120 } & Site & 10 & $32 \mathrm{Cl}$ & none & 3.39 & NA & .10 & 3.14 & 3.51 & 2.423 & .2325 & NA \\
\hline & Site & 10 & $32 \mathrm{SO} 4$ & none & 120.86 & NA & 8.58 & 113.11 & 143.32 & 2.432 & 20.8768 & NA \\
\hline \multirow[t]{2}{*}{ SR120 } & Site & 50 & $35 \mathrm{Cl}$ & none & 3.25 & NA & .09 & 3.10 & 3.45 & 2.443 & .2222 & NA \\
\hline & Site & 50 & $35 \mathrm{SO} 4$ & none & 111.11 & NA & 7.30 & 102.41 & 136.13 & 2.443 & 17.8441 & NA \\
\hline \multirow[t]{2}{*}{ SR121 } & Site & 250 & $12 \mathrm{Cl}$ & none & .32 & NA & .06 & .25 & .46 & 2.718 & .1670 & NA \\
\hline & Site & 250 & $12 S O 4$ & none & 59.14 & NA & 2.28 & 57.03 & 62.30 & 2.718 & 6.1988 & NA \\
\hline
\end{tabular}

Standard reference sample M140 was analyzed only on the $10-\mu \mathrm{L}$ loop. Accuracy declines when the volume on the column declines. Standard reference sample M102 was analyzed predominately on the 50$\mu \mathrm{L}$ loop. Because the most probable values for $\mathrm{Cl}$ and $\mathrm{SO}_{4}$ are outside the linear range of calibration for this loop, the sample is diluted at a ratio of approximately $1: 10$. Accuracy is generally poorer for samples that have been diluted.

Precision is defined as "a measure of the expected reproducibility of a method when it is repeated on a homogeneous sample under controlled conditions, regardless of whether or not the measured concentrations are widely displaced from the true concentration" (Brinton and others, 1996). Mathematically, the precision of a standard, $s$, can be defined as:

$$
P_{s}=\left(S D_{c}\right)\left(t_{9 n-(1,0.99)}\right),
$$

where $S D_{c}$ is the standard deviation of the concentrations for the $n$ duplicates and

$t \quad$ is the student t-statistic at the 99 percent confidence interval for $n-1$ degrees of freedom. 

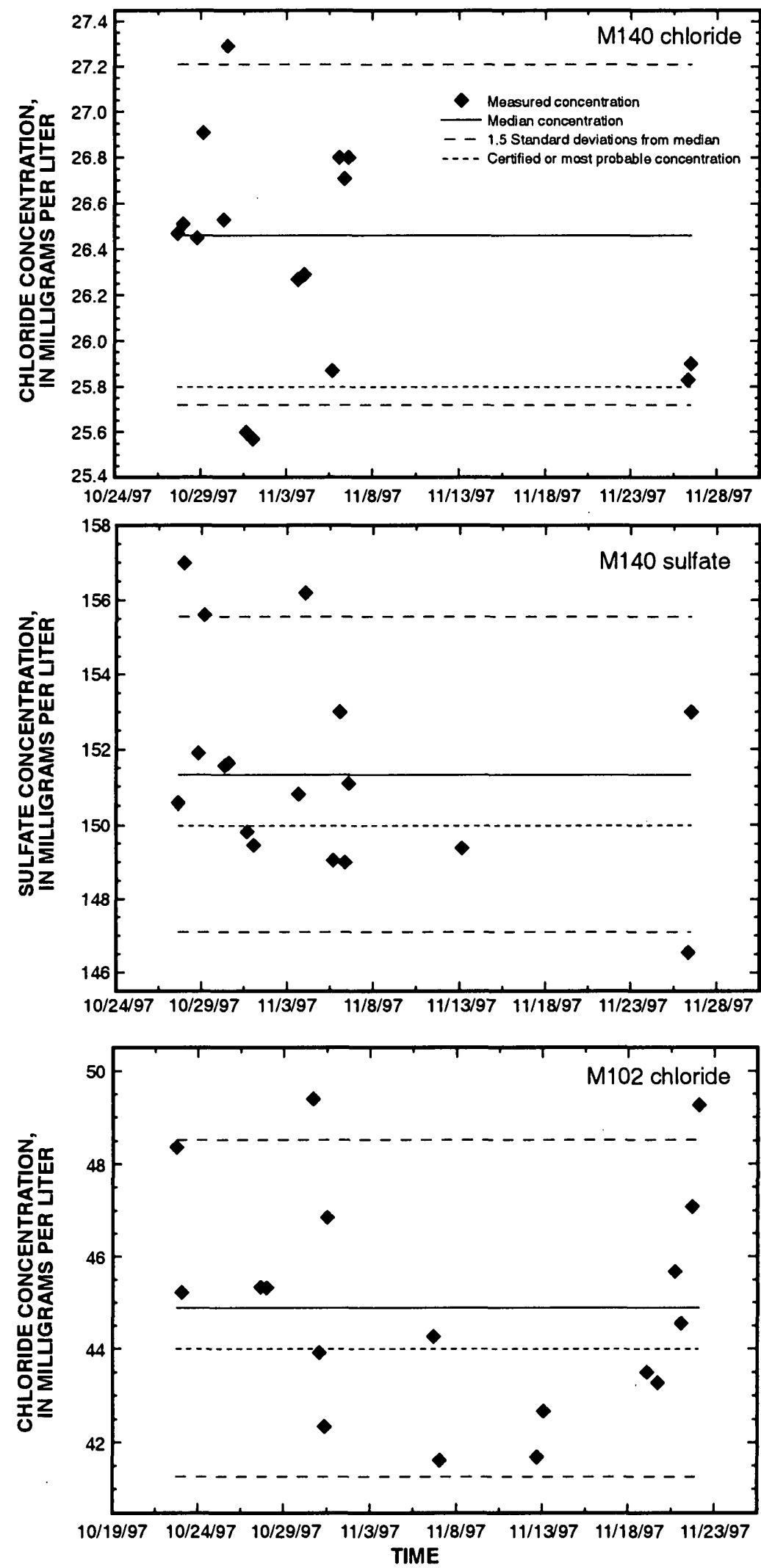

Figure 21. Variation in concentration of chloride and sulfate with time in standard reference samples. 

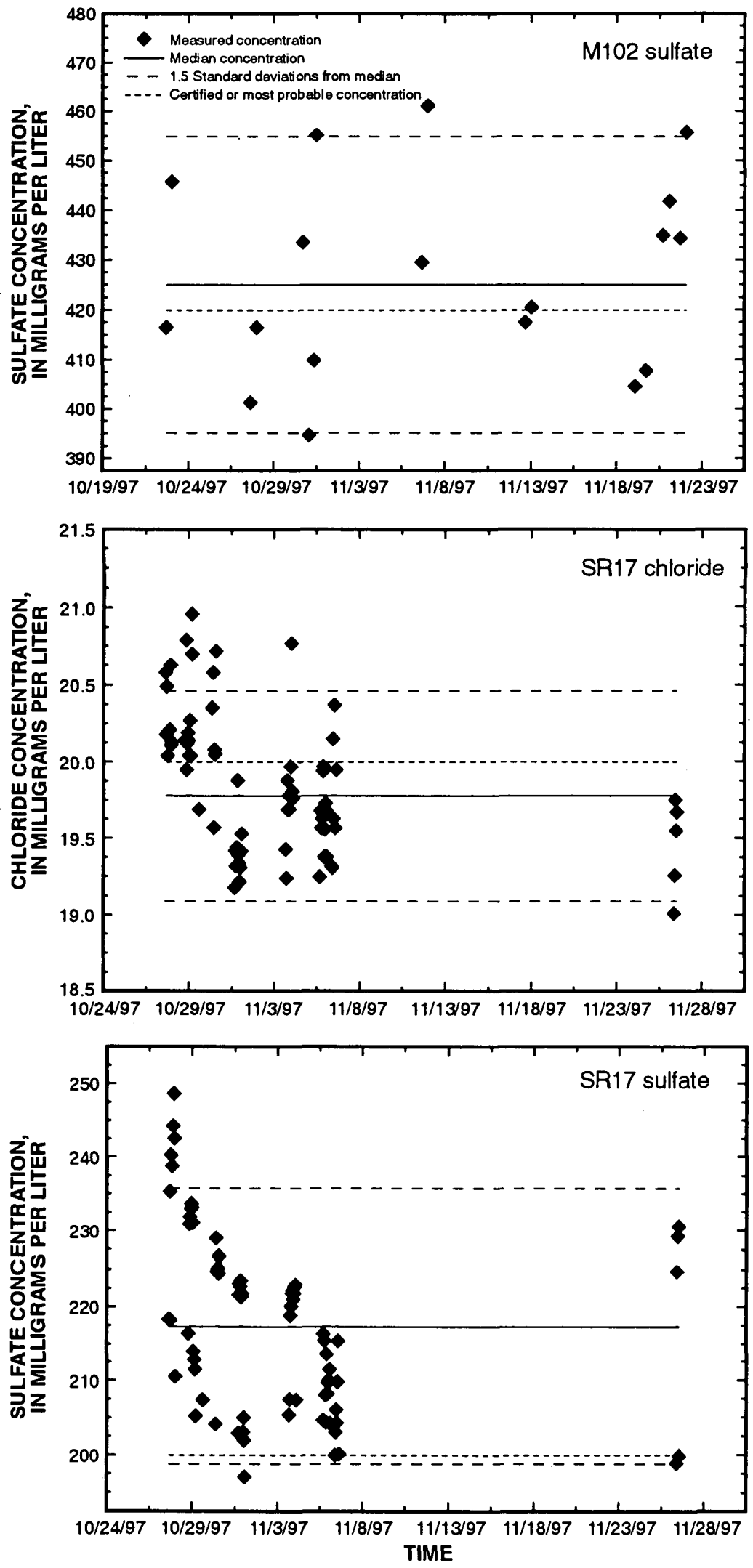

Figure 21. Variation in concentration of chloride and sulfate with time in standard reference samples-Continued 

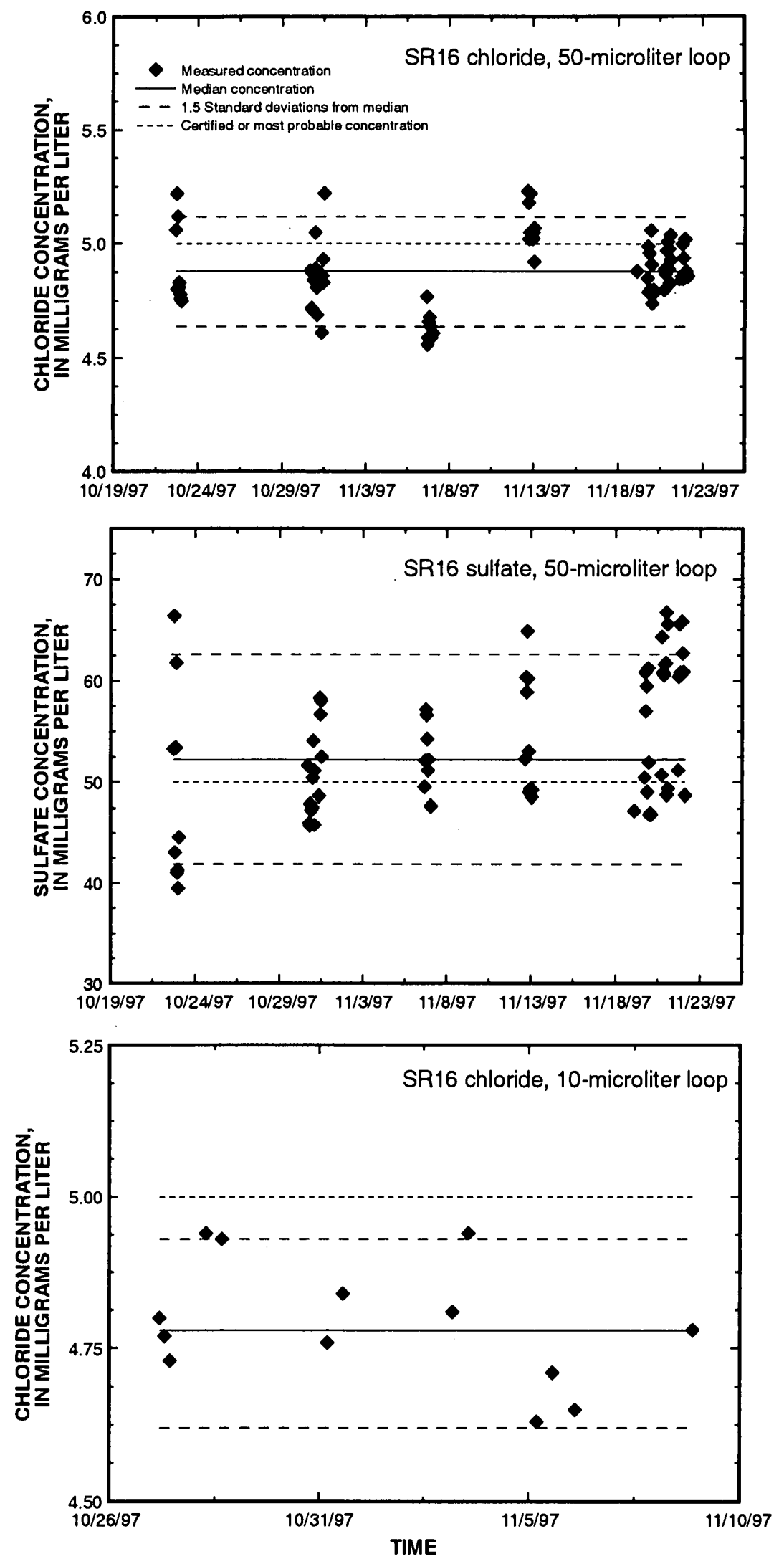

Figure 21. Variation in concentration of chloride and sulfate with time in standard reference samples-Continued. 

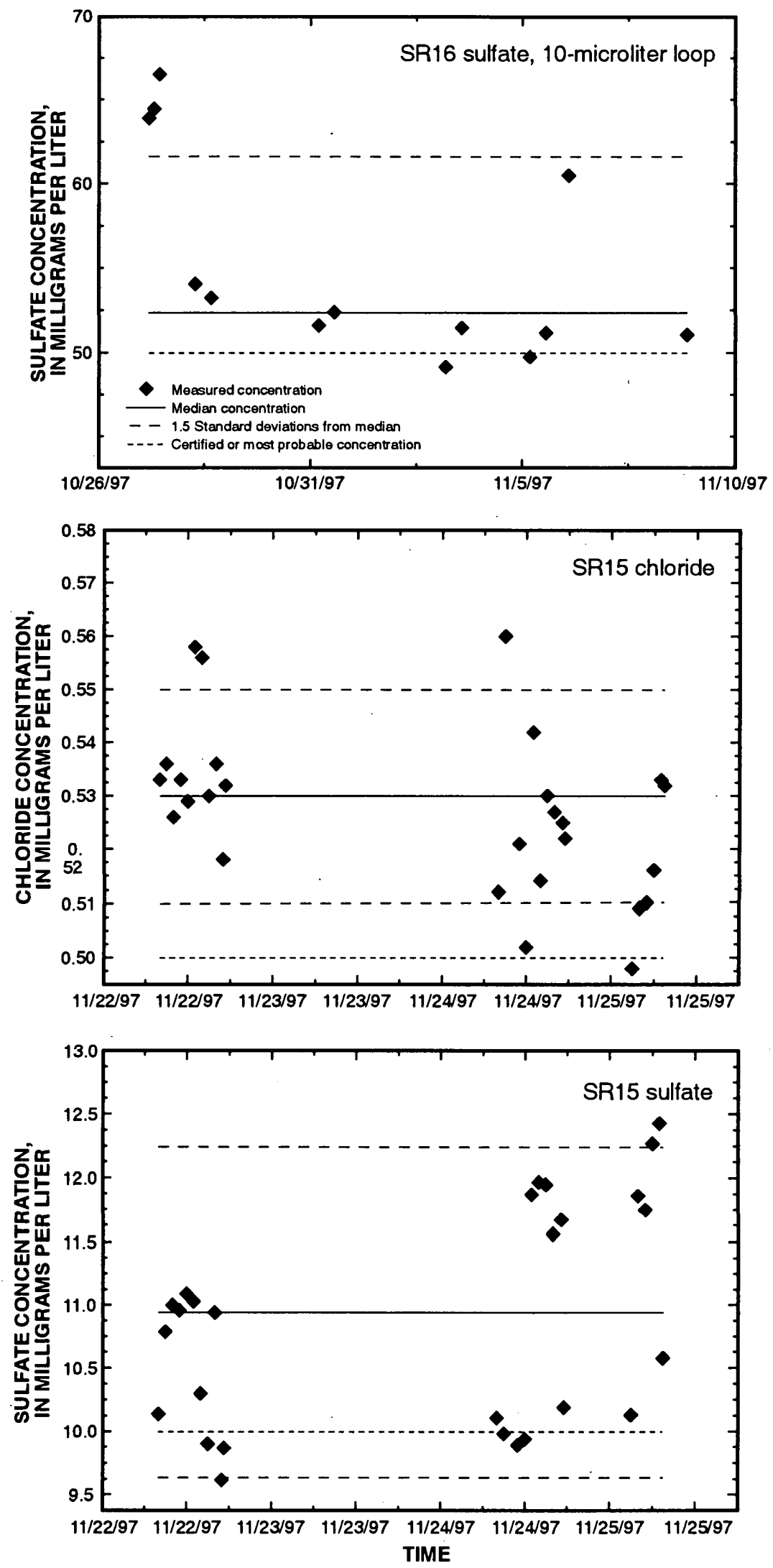

Figure 21. Variation in concentration of chloride and sulfate with time in standard reference samples-Continued. 
Because standard deviations become higher as the analyte concentration becomes higher, percent precision is perhaps a more comparable measure of precision. Percent precision is defined as:

$$
\begin{gathered}
\% P=\left(P_{s} / L C V\right)(100), \\
\text { or } \\
\% P=\left(P_{s} / M P V\right)(100),
\end{gathered}
$$

where $\% P$ is the percent precision,

$P_{s}$ is the precision calculated above,

$L C V$ is the laboratory-certified value, and

$M P V$ is the most probable value.

The percent precision reported in table 8 reflects the overall percent precision for that standard reference sample, loop, and analyte for the time the Fisher Creek samples were being analyzed. Although daily percent precision would likely be better, reproducibility of results for the length of time it takes to complete the analyses for an experiment is more important if daily data are to be merged and compared as a single data set.

Percent precision for $\mathrm{Cl}$ is less than 10 percent for five out of the six standard reference samples. Percent precision ranges from 5.04 percent for $\mathrm{M} 140$ to 14.12 percent for M102. Percent precision for $\mathrm{SO}_{4}$ is larger and indicates much greater variability in results, possibly a result of (1) changing $\mathrm{pH}$ of the sample as it is carried into the column by a sodium-carbonate and bicarbonate eluant, and (or) (2) ongoing precipitation of iron in the autosampler and IC plumbing. Percent precision ranges from 4.87 percent for M140 to 33.08 for SR16 (on the $10-\mu \mathrm{L}$ loop).

Site-specific standards were collected and analyzed to better evaluate analytical precision on site-specific matrices. Although percent precision could not be calculated, precision $\left(P_{c}\right)$ indicates less variability for $\mathrm{Cl}$ and greater variability for $\mathrm{SO}_{4}$ (table 8). 


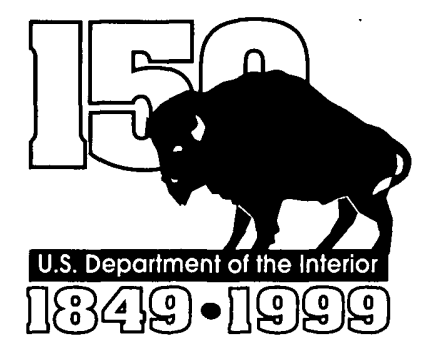

